Prepared in cooperation with the Missouri River Recovery-Integrated Science Program U.S. Army Corps of Engineers, Yankton, South Dakota

\title{
Ecological Requirements for Pallid Sturgeon Reproduction and Recruitment in the Lower Missouri River: A Research Synthesis 2005-08
}
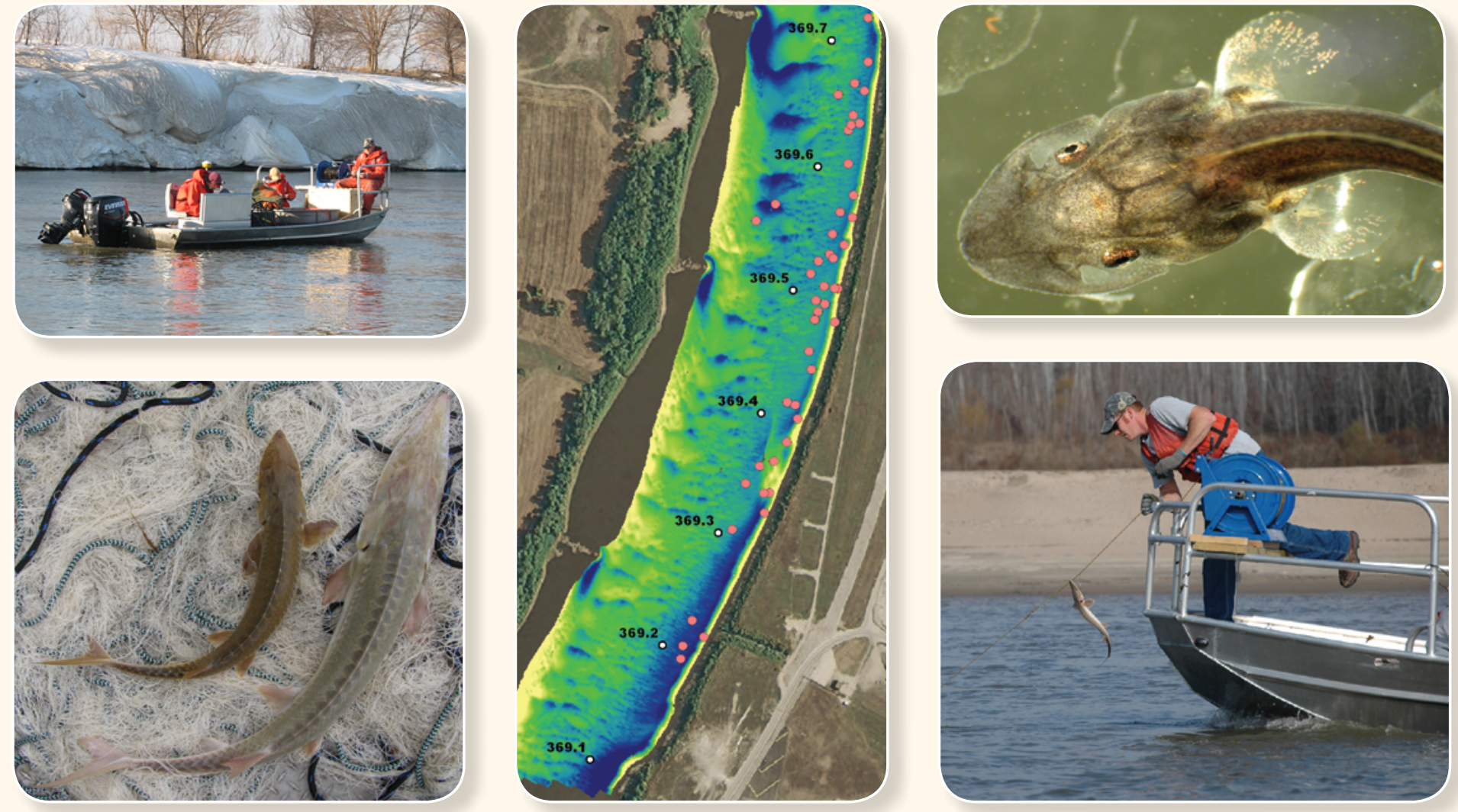

Scientific Investigations Report 2009-5201 


\section{Cover photograph index:}

Early spring sampling for reproductive adult pallid sturgeon on Lower Missouri River.
High-resolution multibeam bathymetric map to characterize habitat around tagged sturgeon locations.
Endangered pallid sturgeon (Scaphirhynchus albus) (right) and shovelnose sturgeon (Scaphirhynchus platorynchus) (left) from the Lower Missouri River, captured as part of the USGS Comprehensive Sturgeon Research Program.
Microscopic image of sturgeon larval stage.

Field researchers capture Scaphirhynchus sturgeon for telemetry studies using baited trotlines.

Photographs by U.S. Geological Survey personnel. 


\section{Ecological Requirements for Pallid Sturgeon Reproduction and Recruitment in the Lower Missouri River: A Research Synthesis 2005-08}

By Aaron J. DeLonay ${ }^{1}$, Robert B. Jacobson', Diana M. Papoulias', Darin G.

Simpkins ${ }^{1}$, Mark. L. Wildhaber ${ }^{1}$, Joanna M. Reuter ${ }^{1}$, Tom W. Bonnot ${ }^{2}$, Kimberly A.

Chojnacki', Carl E. Korschgen' ${ }^{1}$, Gerald E. Mestl ${ }^{3}$, and Michael J. Mac ${ }^{1}$

${ }^{1}$ U.S. Geological Survey, Columbia Environmental Research Center, Columbia, MO

${ }^{2}$ University of Missouri, Columbia, MO

${ }^{3}$ Nebraska Game and Parks Commission, Lincoln, NE

Prepared in cooperation with the Missouri River Recovery-Integrated Science Program

U.S. Army Corps of Engineers, Yankton, South Dakota

Scientific Investigations Report 2009-5201 


\title{
U.S. Department of the Interior \\ KEN SALAZAR, Secretary
}

\author{
U.S. Geological Survey \\ Suzette M. Kimball, Acting Director
}

U.S. Geological Survey, Reston, Virginia: 2009

For more information on the USGS - the Federal source for science about the Earth, its natural and living resources, natural hazards, and the environment, visit http://www.usgs.gov or call 1-888-ASK-USGS

For an overview of USGS information products, including maps, imagery, and publications, visit http://www.usgs.gov/pubprod

To order this and other USGS information products, visit http://store.usgs.gov

Any use of trade, product, or firm names is for descriptive purposes only and does not imply endorsement by the U.S. Government.

Although this report is in the public domain, permission must be secured from the individual copyright owners to reproduce any copyrighted materials contained within this report.

Suggested citation:

DeLonay, A.J., Jacobson, R.B., Papoulias, D.M., Simpkins, D.G., Wildhaber, M.L., Reuter, J.M., Bonnot, T.W., Chojnacki, K.A., Korschgen, C.E., Mestl, G.E. , and Mac, M.J., 2009, Ecological requirements for pallid sturgeon reproduction and recruitment in the Lower Missouri River: A research synthesis 2005-08: U.S. Geological Survey Scientific Investigations Report 2009-5201, 59 p. 


\section{Contents}

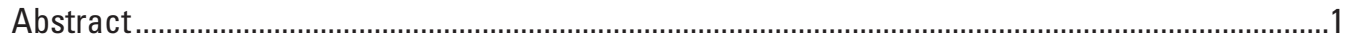

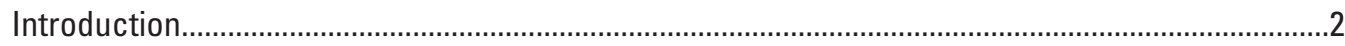

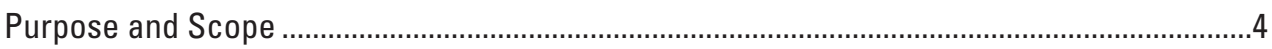

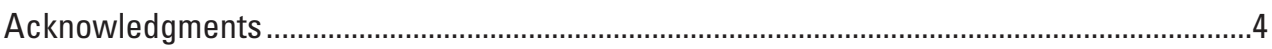

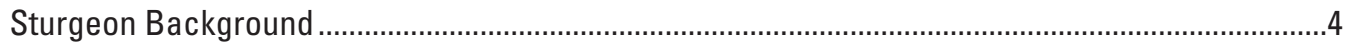

Scaphirhynchus Reproductive Cycle ......................................................................................5

Scaphirhynchus Sturgeon Spawning Behavior ..........................................................................

Scaphirhynchus Sturgeon Early Life History ..........................................................................

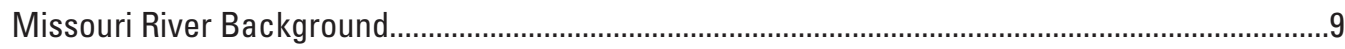

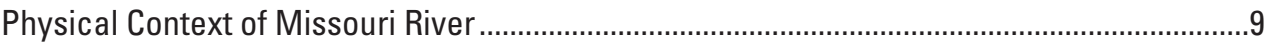

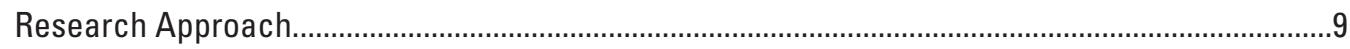

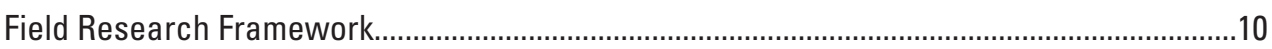

Hydroclimatic Conditions 2005-08 ...................................................................................11

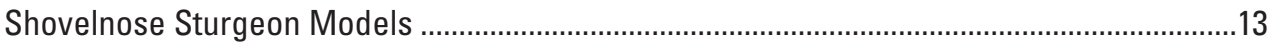

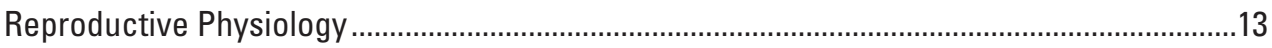

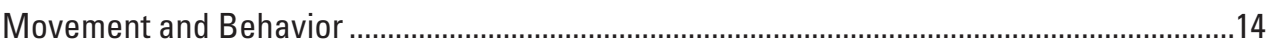

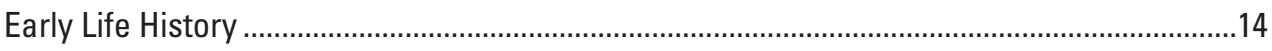

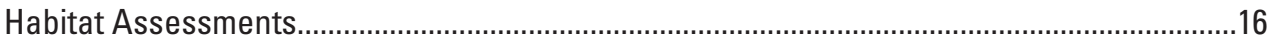

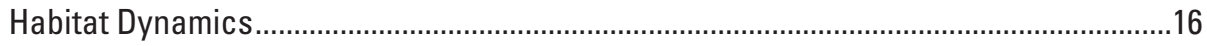

Habitat Availability ........................................................................................................

Habitat Selection …............................................................................................ 16

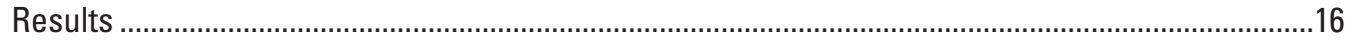

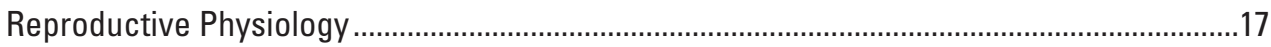

Matching Patterns to Discern Spawning Cues ................................................................17

Gonad Abnormalities and Tumors.......................................................................... 19

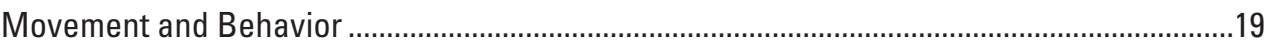

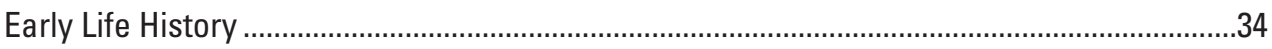

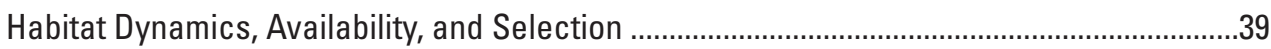

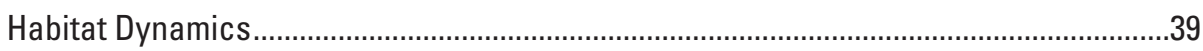

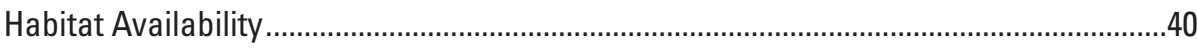

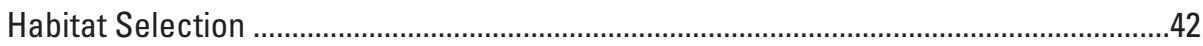

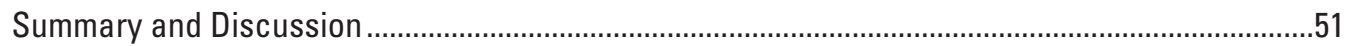

Environmental Cues and Reproductive Readiness .....................................................................51

Implications of Documented Reproductive Movements............................................................53

Implications of Larval Drift Timing and Distance.........................................................................53

Flow and Channel Form Management in Mediating Sturgeon Reproduction ...........................54

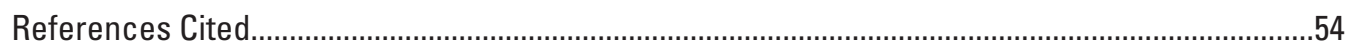




\section{Figures}

1. Map showing Missouri River Basin and major tributary rivers with described range of pallid sturgeon (Bailey and Cross, 1954) (lower left) and Comprehensive Sturgeon Research Program study areas (lower right).

2. Flow chart showing conceptual life-history model of pallid sturgeon. From Wildhaber and others (2007a)

$3-4 . \quad$ Charts showing:

3. Conceptual model of sturgeon reproductive cycle and the expected relation between diagnostic indicators and readiness to spawn.....

4. Conceptual model of Scaphirhynchus sturgeon spawning migration and behavior in the Lower Missouri River.

5-11. Graphs Showing:

5. Missouri River reservoir system storage on March 1 and May 1, 1967-2009, compared to drought precludes (limits below which pulsed-flow modifications are not attempted) and the storage threshold below which pulses may be decreased on a pro-rated basis (U.S. Army Corps of Engineers, 2006). Projections from 2009 are median runoff forecasts (U.S. Army Corps of Engineers, 2008)........11

6. Lower Missouri River hydrograph from 2005-08 with water temperature and estimated spawning times of shovelnose and pallid sturgeon. Data from U.S. Geological Survey National Water Information System (NWIS), available at $h t t p: / /$ waterdata.usgs.gov/nwis.

7. Polarization index (PI) and hormone (17-beta Estradiol and 11 Ketotestosterone) profiles of a population of gravid shovelnose sturgeon that was repeatedly sampled as they migrated up river

8. The relation between spawning readiness, water temperature, and discharge. Stacked bars are the percentage of gravid shovelnose sturgeon collected from the Missouri River with polarization index (PI) less than or equal to 0.07 and PIs greater than 0.07

9. Temporal and spatial distributions of individual gravid shovelnose sturgeon at different stages of readiness to spawn, as indicated by polarization index and estradiol values, spring to fall.

10. Temporal trend in of individual polarization indices of gravid Missouri River shovelnose sturgeon sampled from random and fixed sites within river miles 196.6-97.6 and 811-734

11. Change in E2:KT (estradiol: 11-ketotestosterone) ratio in gravid shovelnose sturgeon from the Missouri River during two years at two locations relative to prevailing flow and temperature conditions. The E2:KT ratio is a diagnostic indicator of readiness to spawn. Estradiol increases very early in spring then decreases as the spawning cycle progresses; 11-ketotestosterone increases later in the cycle, then decreases in close proximity to ovulation.

12. Photographs showing examples of gonadal intersex found in sturgeon from the Missouri River. (A) Arrow denotes small clear early-stage oocytes on immature testis. (B) Arrows denote early vitellogenic oocytes on maturing testes. (C) Arrows denote mature oocytes on mature testes

13. Graph showing incidence of sturgeon with intersex gonads among total male sturgeon caught in the Missouri River between Gavins Point Dam and St. Louis, 2000-08. Numbers above the bars denote the total number of males evaluated.

14-15. Photographs showing:

14. Shovelnose sturgeon captured in the Missouri River with both an ovarian lobe (0) and a testicular lobe (T). 
15. Shovelnose sturgeon from the Missouri River with rare teratoma tumors. Of hundreds of sturgeon collected during 2005-08, four individuals with teratomas were identified. (A) Ventral view. $(B)$ Dorsal view. $(C)$ and $(D)$ Teratomas in body cavities

16-19. Graphs showing:

16. Depth and temperature recorded from data storage tag, discharge from the nearest upstream gages, and telemetry locations for implanted reproductive female shovelnose sturgeon, SNS05-066. Fish was implanted in reproductive condition and later recaptured and determined to have spawned...

17. Displacement of shovelnose sturgeon making an upstream migration in 2005 calculated by subtracting the capture and implantation location from the maximum upstream location. Data are separated by study segment. Hatched bars indicate sturgeon that were recaptured and determined to have spawned or attempted to spawn

18. Telemetry locations for implanted reproductive female shovelnose sturgeon, SNS07-048, SNS07-135, SNS07-154, and SNS07-088. Fish were implanted in reproductive condition in 2007, recaptured later the same year, and determined to have spawned.....

19. Telemetry locations for implanted reproductive male shovelnose sturgeon, SNS07-099, SNS07-070, SNS07-103, and SNS-169. Fish were implanted in reproductive condition.

20. Map showing maximum upstream location (apex) of telemetry-tagged male and female shovelnose sturgeon and apex locations of female sturgeon that were later recaptured and confirmed to have spawned in the upper study segment. All fish were in reproductive condition when implanted

21-22. Graphs showing:

21. Depth and temperature recorded from data storage tag, discharge from the nearest upstream gage, and telemetry locations for implanted reproductive pallid sturgeon PLS07-007. Fish was implanted in reproductive condition, later recaptured, and determined to have spawned

22. Depth and temperature recorded from data storage tag, discharge from the nearest upstream gage, and telemetry locations for implanted reproductive pallid sturgeon PLS07-004. Fish was implanted in reproductive condition, later recaptured, and determined to have spawned

23. Map showing Lower Missouri River segments and maximum upstream location (apex) of telemetry-tagged female pallid sturgeon in 2007 and 2008. All fish were in reproductive condition when implanted, were tracked to their presumed spawning location, then recaptured, and determined to have spawned

24-32. Graphs showing:

24. Length-weight relationship for wild and hatchery-origin pallid sturgeon collected during 2008 spring sampling efforts in both the upper and lower study segments

25. Depth and temperature recorded from data storage tag, discharge from the nearest upstream gages, and telemetry locations for implanted reproductive pallid sturgeon PLS08-004. Fish was implanted in reproductive condition, later recaptured, and determined to have spawned

26. Depth and temperature recorded from data storage tag, discharge from the nearest upstream gage, and telemetry locations for implanted reproductive pallid sturgeon PLS08-008. Fish was implanted in reproductive condition, later recaptured, and determined to have spawned 
27. Depth and temperature recorded from data storage tag, discharge from the nearest upstream gage, and telemetry locations for implanted reproductive pallid sturgeon PLS08-009. Fish was implanted in reproductive condition, later recaptured, and determined to have spawned.....

28. Depth and temperature recorded from data storage tag, discharge from the nearest upstream gage, and telemetry locations for implanted reproductive pallid sturgeon PLS08-014. Fish was implanted in reproductive condition, later recaptured, and determined to have spawned....

29. Discharge, water temperatures, and air temperatures from May to June, 2008. Temperature events associated with interruption in the migration of PLS08014 show that water temperature declined at Sioux City as a result of an air temperature drop and was not associated with increased flow from Gavins Point Dam or tributaries

30. Plot of normalized habitat variables (daily flow coefficient of variation, channel width:depth ratio, annual suspended sediment load) by river mile showing variability in habitat-controlling factors along the Lower Missouri River and 3-part longitudinal division. Habitat variables are normalized by the maximum (most natural) value of each variable

31. Histograms indicating habitat availability and habitat use, and bar charts of selectivity coefficient, by major river section. Selectivity ranges from -1 (strong avoidance) to 0 (no selection) to +1 (selection) (Reuter and others, 2009).

32. Spatial representation $(A)$ and demonstrated effects $(B)$ of physical aquatic habitat variables included in a model explaining habitat selection by female shovelnose sturgeon in the lower segment of the Lower Missouri River during the 2005 spawning season.

33. Map showing multibeam bathymetric map of spawning location of PLS08-004 near river mile 369.5 in 2008

34. Graph showing hypothetical roles of flow regime in pallid sturgeon reproduction and recruitment

\section{Tables}

1. Mean annual discharge at Sioux City, lowa, and Boonville, Missouri, 1967-2008, with mean daily discharge and annual exceedance for 2005-08

2. Numbers of pallid sturgeon and shovelnose sturgeon implanted with transmitters and recaptured in two Lower Missouri River study areas, 2005-08.

3. Frequency of larval sturgeon collected with time in river segments and major tributaries in the Lower Missouri River

4. Mean total length of sturgeon larvae collected with time in river segments and major tributaries of the Lower Missouri River

5. Collections of sturgeon larvae greater than 10 millimeters total length and estimated ages and origins with information about corresponding collections of day-0 larvae within or near estimated time of hatch and origins

6. Calculated river mile at which pallid sturgeon larvae would settle out from drift, based on 9, 13, and 17 days drift time (Kynard and others, 2002; Braaten and others, 2008) and reach-average velocities of 0.7 and 1.2 meters per second (Reuter and others, 2008)

7. Summary of categorical data by river section, including percent of map area, percent of relocations, and Ivlev's selectivity coefficient. 


\section{Conversion Factors, Abbreviations, and Datums}

\begin{tabular}{|c|c|c|}
\hline Multiply & By & To obtain \\
\hline \multicolumn{3}{|c|}{ Length } \\
\hline mile (mi) & 1.609 & kilometer $(\mathrm{km})$ \\
\hline \multicolumn{3}{|c|}{ Flow rate } \\
\hline cubic foot per second $\left(\mathrm{ft}^{3} / \mathrm{s}\right)$ & 0.02832 & cubic meter per second $\left(\mathrm{m}^{3} / \mathrm{s}\right)$ \\
\hline
\end{tabular}

\section{SI to Inch/Pound}

\begin{tabular}{|c|c|c|}
\hline Multiply & By & To obtain \\
\hline \multicolumn{3}{|c|}{ Length } \\
\hline micrometer $(\mu \mathrm{m})$ & 0.0000397 & inch (in.) \\
\hline millimeter $(\mathrm{mm})$ & 0.03937 & inch (in.) \\
\hline centimeter $(\mathrm{cm})$ & 0.3937 & inch (in.) \\
\hline meter $(\mathrm{m})$ & 3.281 & foot $(\mathrm{ft})$ \\
\hline kilometer $(\mathrm{km})$ & 0.6214 & mile (mi) \\
\hline meter (m) & 1.094 & yard (yd) \\
\hline \multicolumn{3}{|c|}{ Area } \\
\hline square meter $\left(\mathrm{m}^{2}\right)$ & 10.76 & square foot $\left(\mathrm{ft}^{2}\right)$ \\
\hline hectare (ha) & 0.003861 & square mile $\left(\mathrm{mi}^{2}\right)$ \\
\hline square kilometer $\left(\mathrm{km}^{2}\right)$ & 0.3861 & square mile $\left(\mathrm{mi}^{2}\right)$ \\
\hline \multicolumn{3}{|c|}{ Volume } \\
\hline cubic meter $\left(\mathrm{m}^{3}\right)$ & 264.2 & gallon (gal) \\
\hline cubic meter $\left(\mathrm{m}^{3}\right)$ & 35.31 & cubic foot $\left(\mathrm{ft}^{3}\right)$ \\
\hline cubic meter $\left(\mathrm{m}^{3}\right)$ & 1.308 & cubic yard $\left(\mathrm{yd}^{3}\right)$ \\
\hline \multicolumn{3}{|c|}{ Flow rate } \\
\hline meter per second $(\mathrm{m} / \mathrm{s})$ & 3.281 & foot per second (ft/s) \\
\hline cubic meter per second $\left(\mathrm{m}^{3} / \mathrm{s}\right)$ & 35.31 & cubic foot per second $\left(\mathrm{ft}^{3} / \mathrm{s}\right)$ \\
\hline \multicolumn{3}{|c|}{ Mass } \\
\hline $\operatorname{gram}(\mathrm{g})$ & 0.03527 & ounce, avoirdupois (oz) \\
\hline kilogram (kg) & 2.205 & pound avoirdupois (lb) \\
\hline
\end{tabular}

To communicate effectively with stakeholders, managers, and other scientists working on the Lower Missouri River, this report uses a mix of U.S. customary units and International System of Units (SI) units of measure. Distances along the Missouri River are given in river miles upstream from the junction with the Mississippi River at St. Louis, Missouri, as measured by the U.S. Army Corps of Engineers in 1960. Discharges are provided in the customary units of cubic feet per second. Reach-scale hydraulic variables—depth and velocity-are in SI units of meters and meters per second.

Temperature in degrees Celsius $\left({ }^{\circ} \mathrm{C}\right)$ may be converted to degrees Fahrenheit $\left({ }^{\circ} \mathrm{F}\right)$ as follows:

$$
{ }^{\circ} \mathrm{F}=\left(1.8 \times{ }^{\circ} \mathrm{C}\right)+32
$$

Vertical coordinate information is referenced to the North American Vertical Datum of 1988 (NAVD 88)

Horizontal coordinate information is referenced to the World Geodetic System of 1984 (WGS 84) 



\title{
Ecological Requirements for Pallid Sturgeon Reproduction and Recruitment in the Lower Missouri River: A Research Synthesis 2005-08
}

\author{
By Aaron J. DeLonay, Robert B. Jacobson, Diana M. Papoulias, Darin G. Simpkins, Mark. L. Wildhaber, \\ Joanna M. Reuter, Tom W. Bonnot, Kimberly A. Chojnacki, Carl E. Korschgen, Gerald E. Mestl, and Michael J. \\ Mac
}

\section{Abstract}

This report provides a synthesis of results obtained between 2005 and 2008 from the Comprehensive Sturgeon Research Program, an interagency collaboration between the U.S. Geological Survey, Nebraska Game and Parks Commission, U.S. Fish and Wildlife Service, and the U.S. Army Corps of Engineers' Missouri River Recovery-Integrated Science Program. The goal of the Comprehensive Sturgeon Research Program is to improve fundamental understanding of reproductive ecology of the pallid sturgeon with the intent that improved understanding will inform river and species management decisions. Specific objectives include:

- Determining movement, habitat-use, and reproductive behavior of pallid sturgeon;

- Understanding reproductive physiology of pallid sturgeon and relations to environmental conditions;

- Determining origin, transport, and fate of drifting pallid sturgeon larvae, and evaluating bottlenecks for recruitment of early life stages;

- Quantifying availability and dynamics of aquatic habitats needed by pallid sturgeon for all life stages; and

- Managing databases, integrating understanding, and publishing relevant information into the public domain.

Management actions to increase reproductive success and survival of pallid sturgeon in the Lower Missouri River have been focused on flow regime, channel morphology, and propagation. Integration of 2005-08 Comprehensive Sturgeon Research Program research provides insight into linkages among flow regime, re-engineered channel morphology, and pallid sturgeon reproduction and survival.

The research approach of the Comprehensive Sturgeon Research Program integrates opportunistic field studies, fieldbased experiments, and controlled laboratory studies. The field study plan is designed to explore the role of flow regime and associated environmental cues using two complementary approaches. An upstream-downstream approach compares sturgeon reproductive behavior between an upstream section of the Lower Missouri River with highly altered flow regime to a downstream section that maintains much of its preregulation flow variability. The upstream section also has the potential for an experimental approach to compare reproductive behavior in years with pulsed flow modifications ("spring rises") to years without.

The reproductive cycle of the female sturgeon requires several years to progress through gonadal development, oocyte maturation, and spawning. Converging lines of evidence support the hypothesis that maturation and readiness to spawn in female sturgeon is cued many months before spawning. Information on reproductive readiness of shovelnose sturgeon indicates that sturgeon at different locations along the Lower Missouri River between St. Louis and Gavins Point Dam are all responding to the same early cue. Although not a perfect surrogate, the more abundant shovelnose sturgeon is morphologically, physiologically, and genetically similar to pallid sturgeon, and thereby provides a useful comparative model for the rarer species. Day length is the likely candidate to define a temporal spawning window. Within the spawning window, one or more additional, short-term, and specific cues may serve to signal ovulation and release of gametes. Of three potential spawning cues - water temperature, water discharge, and day of year - water temperature is the most likely proximate cue because of the fundamental physiological role temperature plays in sturgeon embryo development and survival, and the sensitivity of many fish hormones to temperature change. It also is possible that neither temperature nor discharge is cueing spawning; instead, reproductive behavior may result from the biological clock advancing an individual fish's readiness to spawn day after day through the spawning period until the right moment, independent of local environmental conditions. Separation of the individual effects of discharge events, water temperature, and other possible factors, such as proximity to males, will require additional well-controlled field experi- 
ments (for example, pulsed flow modifications from Gavins Point Dam) combined with focused laboratory studies.

Telemetry derived movement and behavior data for shovelnose and pallid sturgeon indicate consistent patterns of upstream spawning migrations before spawning. Shovelnose sturgeon seem to be spawning at many locations, and spawning of the population occurs for an extended time ( 1 to 2 months). Movement patterns vary between sexes; female sturgeon generally move upstream and spawn at the apex of their migration, whereas males choose to migrate upstream to one or several spawning locations, or choose to remain relatively sedentary. Environmental changes such as temperature fluctuations or extreme flow events may slow or disrupt spawning migrations or inhibit spawning. Limited information indicates that patterns of migratory behavior of pallid sturgeon are similar to shovelnose sturgeon. Additional information is needed on pallid sturgeon to determine whether or not this species spawns during the same period, spatial extent, or range of environmental conditions.

Tracking gravid (reproductive) female shovelnose and pallid sturgeon from 2004-07 narrowed delineations of spawning habitat. In 2008, three separate pallid sturgeon spawning patches were resolved to areas of several hundreds of square meters by intensive tracking of three gravid female pallid sturgeon of hatchery origin. Each of the three geographically separated patches was on the outside of a revetted bend, with deep, relatively fast, and turbulent flow. Because this is a common habitat on the Lower Missouri River, these results support the hypothesis that spawning habitat availability is not a limiting factor in pallid sturgeon reproduction in the Lower Missouri River.

Spawning at many locations scattered over a large spatial extent and over an extended period may decrease the likelihood of sturgeon finding suitable mates, and thereby increase the potential for reproductive failure or hybridization. Widely distributed spawning also may reduce the effectiveness of short-duration flow modifications or discrete habitat restoration projects in species recovery.

This study was the first to document spawning of pallid sturgeon in the Lower Missouri River. Two wild pallid females were tracked to apices of their migration in 2007; when subsequently recaptured, they were determined to have spawned completely. We have also documented spawning of hatcherypropagated pallid sturgeon in the Lower Missouri River, indicating that hatchery progeny are surviving, growing, reaching reproductive maturity, and are now potentially contributing a new generation of fish. Although this is a significant measure of success for the species recovery program, uncertainties remain about whether or not spawning results in successful recruitment to the population.

Our results support the hypothesis that spawning location, water velocities, growth rates, and drift dynamics determine the spatial and temporal distribution of pallid and shovelnose sturgeon larvae and juveniles in the Missouri River. Calculations based on mean reach velocities indicate that drifting larvae that hatch along much of the Lower Missouri
River have the potential to drift into the Mississippi River. Habitat restoration activities that facilitate spawning further upstream, increase river length (by restoring cut-off channels), or decrease drift distance (for example, by decreasing mean velocities or increasing channel width and habitat complexity) may assist in recruiting Scaphirhynchus sturgeon in the Missouri River. Moreover, understanding of typical drift distances of larval Scaphirhynchus sturgeon may provide useful guidance for placement of channel-restoration projects intended to provide rearing habitat. Our drift calculations indicate that with present (2009) reach-averaged velocities, rearing habitat would be most beneficial to pallid sturgeon downstream from river mile 378, near the Kansas River confluence. Whether or not such habitat is limiting for survival of larval sturgeon has not yet been determined. The potential for Missouri River larvae to drift into the Mississippi River indicates a need to understand habitat functions and fate of larvae far downstream from spawning sites and to integrate understanding of sturgeon life history for a geographic area that includes the Missouri and Mississippi Rivers.

Assessments of habitat dynamics indicate that most habitat categories change little in area with changes in discharge that would occur with proposed pulse-flow modifications. In contrast, morphodynamic assessments indicated that flows similar in magnitude to pulse-flow modifications are capable of transporting sediment and altering habitat substrate at the local scale. Whether or not pulsed flows can "condition" spawning substrate at the right time, in the right place, and in patches of the right size for successful pallid sturgeon spawning remain unknown. Improved understanding of where and when sturgeon spawn will be necessary to address these questions. Our assessments of habitat availability and use indicate that migrating adult sturgeon use specific areas within available habitats, characterized by high variability of depth and velocity, and low ratios of velocity to depth. Selection of these habitats provides insight into combinations of flow and channel form that support the energetic requirements of migrating fish. Diminished areas of these habitats in the upper channelized section of the river may indicate that habitat is more limiting in this part of the river compared to upstream and downstream sections. Lack of suitable migration habitat in the upper channelized section may indicate a reproductive bottleneck if fish are energetically limited in their migration to spawning areas or in finding mates.

\section{Introduction}

The pallid sturgeon (Scaphirhynchus albus) is endemic to the Missouri River and the Middle and Lower Mississippi River from near the mouth of the Missouri River downstream to the Gulf of Mexico (fig. 1) (Mayden and Kuhajda, 1997). It was listed as a federally endangered species under the Endangered Species Act in 1990 (55 FR36641-36647) by the U.S. Fish and Wildlife Service (USFWS) because of extensive 


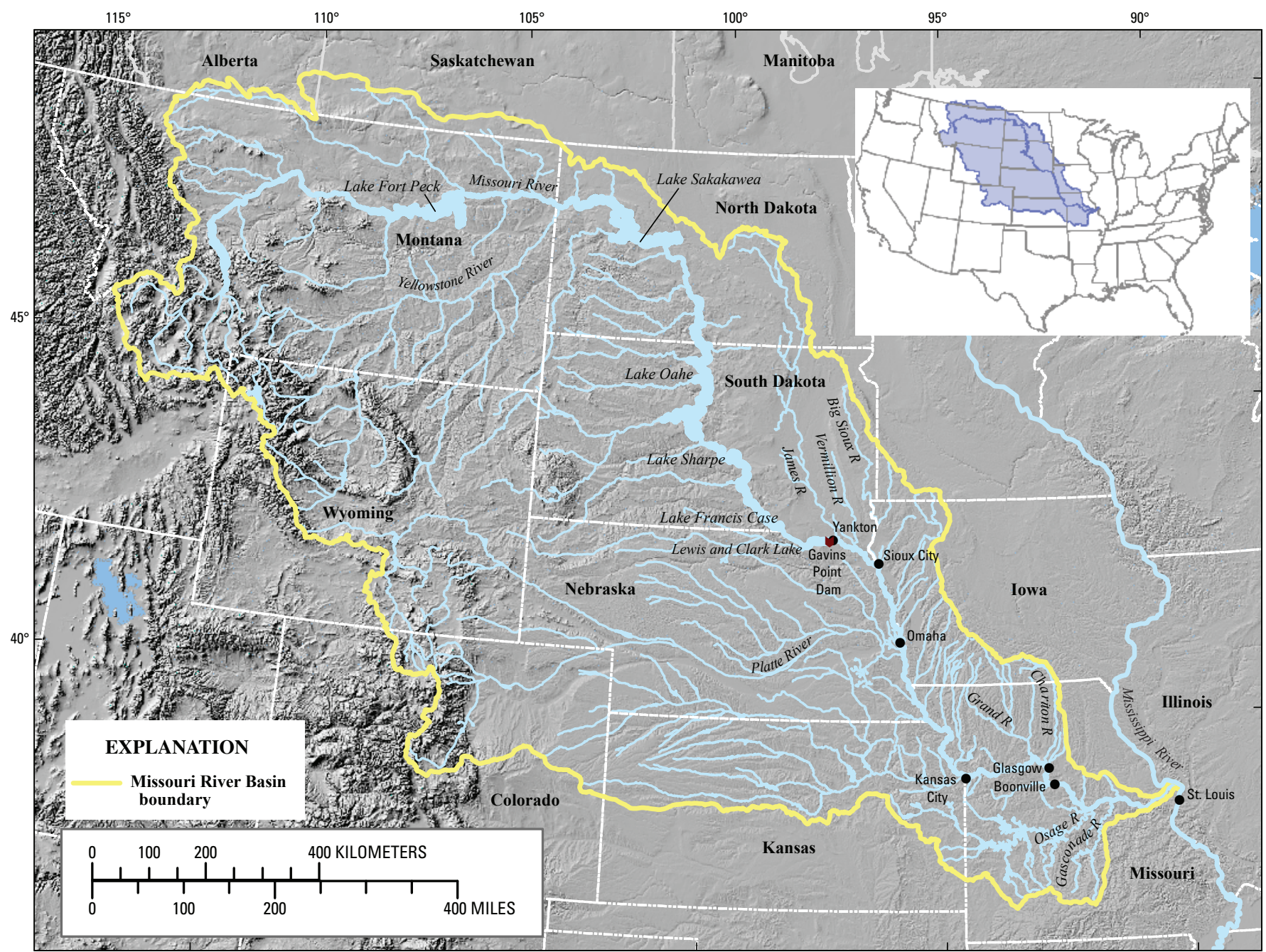

Base data from the National Atlas, 2006

Universal Transverse Mercator projection

Zone 15
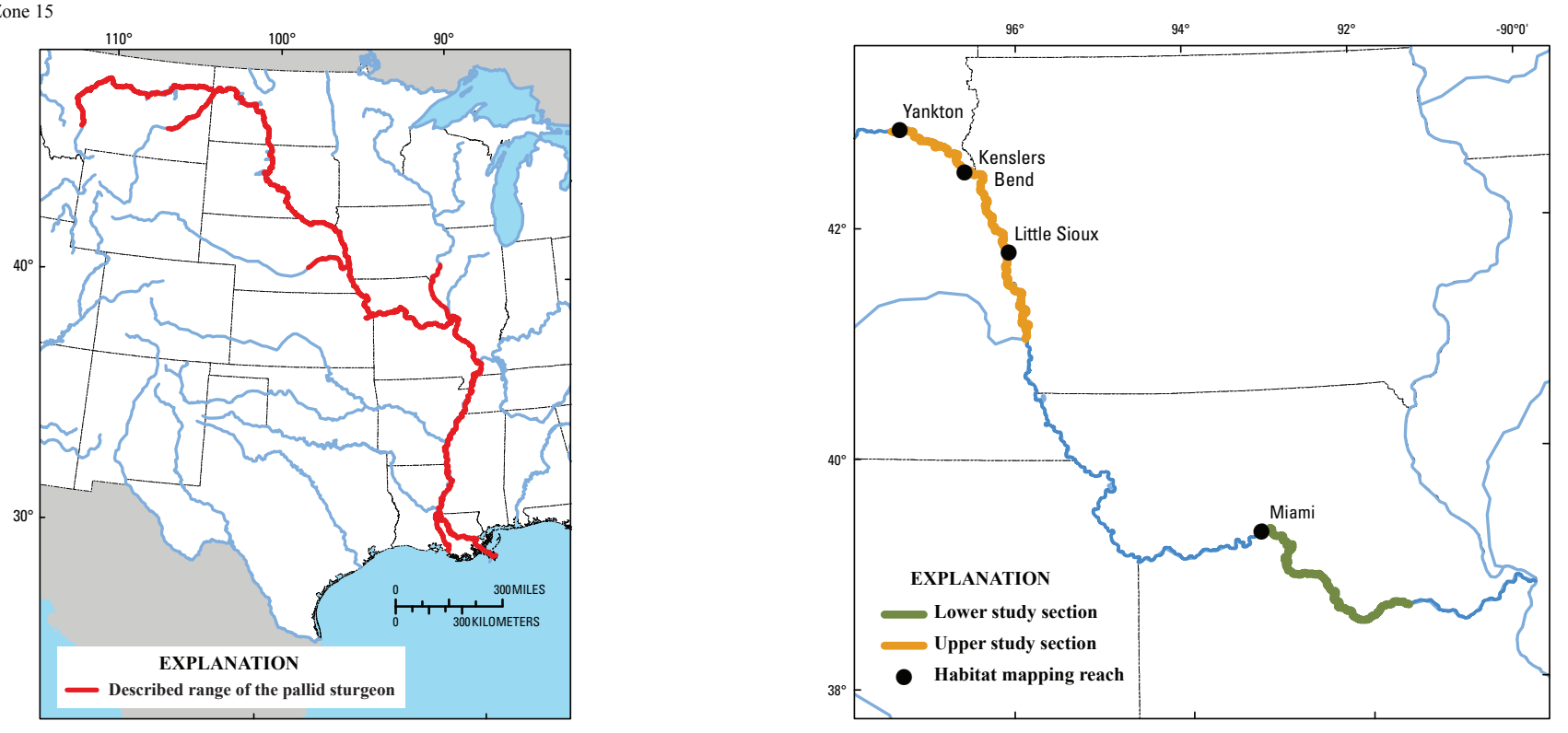

Figure 1. Missouri River Basin and major tributary rivers with described range of pallid sturgeon (Bailey and Cross, 1954) (lower left) and Comprehensive Sturgeon Research Program study areas (lower right). 
habitat modification, an apparent lack of reproduction and recruitment, commercial harvest, and hybridization with shovelnose sturgeon (Dryer and Sandvol, 1993).

Recovery of the species in the Missouri River (fig. 1) depends on improving the understanding of ecological factors that contribute to successful pallid sturgeon reproduction and survival. Presently, (2009) recovery actions are guided by biological opinions, issued in 2000 and 2003 (U.S. Fish and Wildlife Service, 2000; 2003). The biological opinions emphasize naturalization of the flow regime to provide flow-related cues and to synchronize flow pulses, temperature, and turbidity; reconfiguration of the channel to provide more diverse aquatic habitat and to increase areas of shallow, slow water [shallow-water habitat (SWH) defined as $0-1.5 \mathrm{~m}$ depth and $0-0.6 \mathrm{~m} / \mathrm{s}$ current velocity]; and increased hatchery propagation. However, there remains little quantitative understanding of how management actions and consequent physical changes to the river environment affect sturgeon reproduction and survival (Bergman and others, 2008). Moreover, little is known about the interacting roles of water quality and contaminants, or biotic factors like nutrition, competition, predation, and productivity.

\section{Purpose and Scope}

The purpose of this report is to synthesize research on pallid sturgeon reproductive ecology from 2005-08. In 2005, scientists at the U.S. Geological Survey (USGS) developed an interdisciplinary research program at the request of the U.S. Army Corps of Engineers. The Comprehensive Sturgeon Research Program (CSRP) was designed to assess how different life stages and essential activities of sturgeon respond to a range of ecological factors. The CSRP has evolved into an interagency collaboration of the USGS, Nebraska Game and Parks Commission, U.S. Fish and Wildlife Service, and the U.S. Army Corps of Engineers' Missouri River RecoveryIntegrated Science Program.

The goal of CSRP is to improve fundamental understanding of reproductive ecology of the pallid sturgeon and thereby support decisions on river and species management. Specific research objectives include:

- Determine movement, habitat-use, and reproductive behavior of pallid sturgeon;

- Understand reproductive physiology of pallid sturgeon and relations to environmental conditions;

- Determine origin, transport, and fate of drifting pallid sturgeon larvae, and evaluate bottlenecks for recruitment of early life stages;

- Quantify availability and dynamics of aquatic habitats needed by pallid sturgeon for all life stages; and

- Manage databases, integrate understanding, and publish relevant information into the public domain.
The CSRP direction has been guided by results of sturgeon research workshops convened in 2004 (Quist and others, 2004) and 2007 (Bergman and others, 2008); by hypotheses that emerged about the role of a naturalized flow regime in pallid sturgeon reproduction during a series of workshops in 2005 (Jacobson and Galat, 2008); and by feedback from an independent science review (Sustainable Ecosystems Institute, 2008). Research objectives also have emphasized science information gaps related to priority management issues, including understanding the role of pulsed flow releases from Gavins Point Dam and understanding of the functions of constructed shallow-water habitat in the sturgeon life cycle.

The CSRP research direction also has been guided by a conceptual sturgeon life-history model (Wildhaber and others, 2007a) that was developed to organize understanding of the reproductive ecology of the pallid sturgeon, to illustrate key unknowns, and to help managers visualize pallid sturgeon recovery efforts (fig. 2). Two features of the model have been salient in affecting CSRP research. First, the model illustrates that multiple life-stage transitions potentially can act as population bottlenecks, indicating that processes and conditions at a variety of life stages may need to be understood to manage sturgeon populations. Second, the model illustrates that pallid sturgeon migrate long distances upstream (DeLonay and others, 2007b) and their larvae drift long distances downstream (Braaten and others, 2008); therefore, processes and conditions to support different life stages play out on different parts of the river system. Understanding the geography of habitat potential along the river is key to understanding how to manage habitat needs of specific life stages.

\section{Acknowledgments}

This report benefited from technical reviews by James Garvey, Michael Parsley, Craig Fleming, and Roy McAllister. Funding for this research was provided by the U.S. Army Corps of Engineers, Missouri River Recovery - Integrated Science Program and the USGS.

\section{Sturgeon Background}

The CSRP is based on a foundation of available information, including information on reproductive ecology of closely related sturgeon species; information developed in laboratories, hatcheries, and in the river systems; and general ecological theory. This understanding has provided initial conceptual models that have evolved as new information is developed, specifically for the pallid sturgeon and the Lower Missouri River. The following sections present an overview of existing information on the reproduction, spawning behavior, and early life history of Scaphirhynchus sturgeon. 

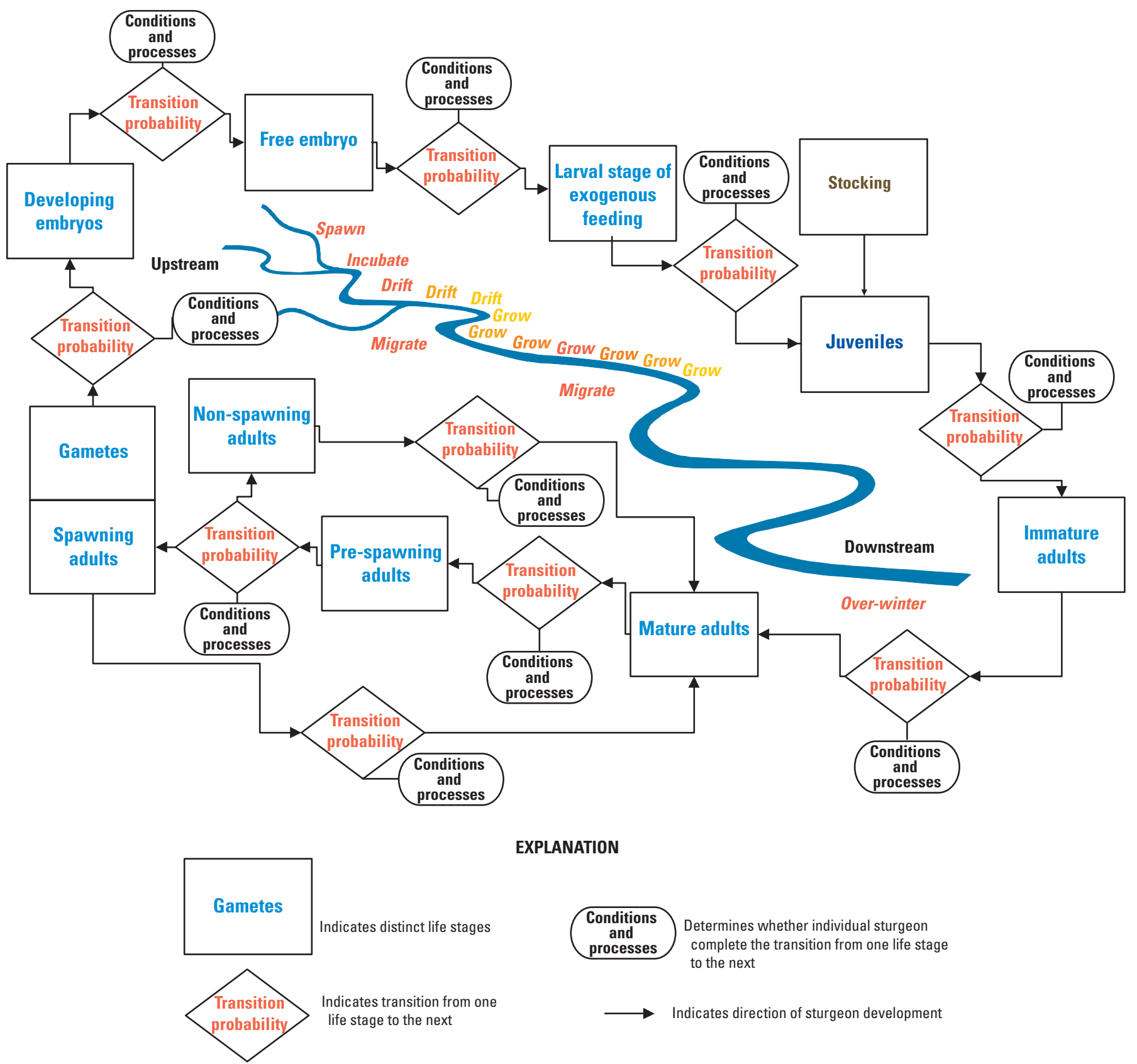

EXPLANATION

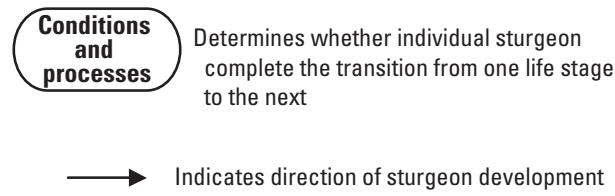

Figure 2. Conceptual life-history model of pallid sturgeon. From Wildhaber and others (2007a).

\section{Scaphirhynchus Reproductive Cycle}

The reproductive cycle of fishes is controlled temporally by complex interactions of environmental factors so that fish generally spawn at an optimal time for survival of their offspring (Munro and others, 1990). The optimal period for spawning may be characterized by several environmental factors such as season, temperature, habitat, presence of a mate, presence of food, or absence of predators. In fish species with extended reproductive cycles and long periods between spawning (more than one year), such as shovelnose and pallid sturgeon, long- and short-term cues likely control different specific physiological and behavioral functions (Munro and others, 1990). For example, cues may be necessary at different times to initiate oocyte maturation, stimulate migration, begin ovulation, or complete spawning. Understanding the relative roles of long- and short-term environmental factors and cues determining reproductive success is central to identifying management strategies for recovery of Missouri River sturgeon.

Shovelnose and pallid sturgeon in the Missouri River are thought to have evolved to spawn in the springtime, presumably when various factors would optimize success under natural conditions (Keenlyne, 1997). Female shovelnose and pallid 


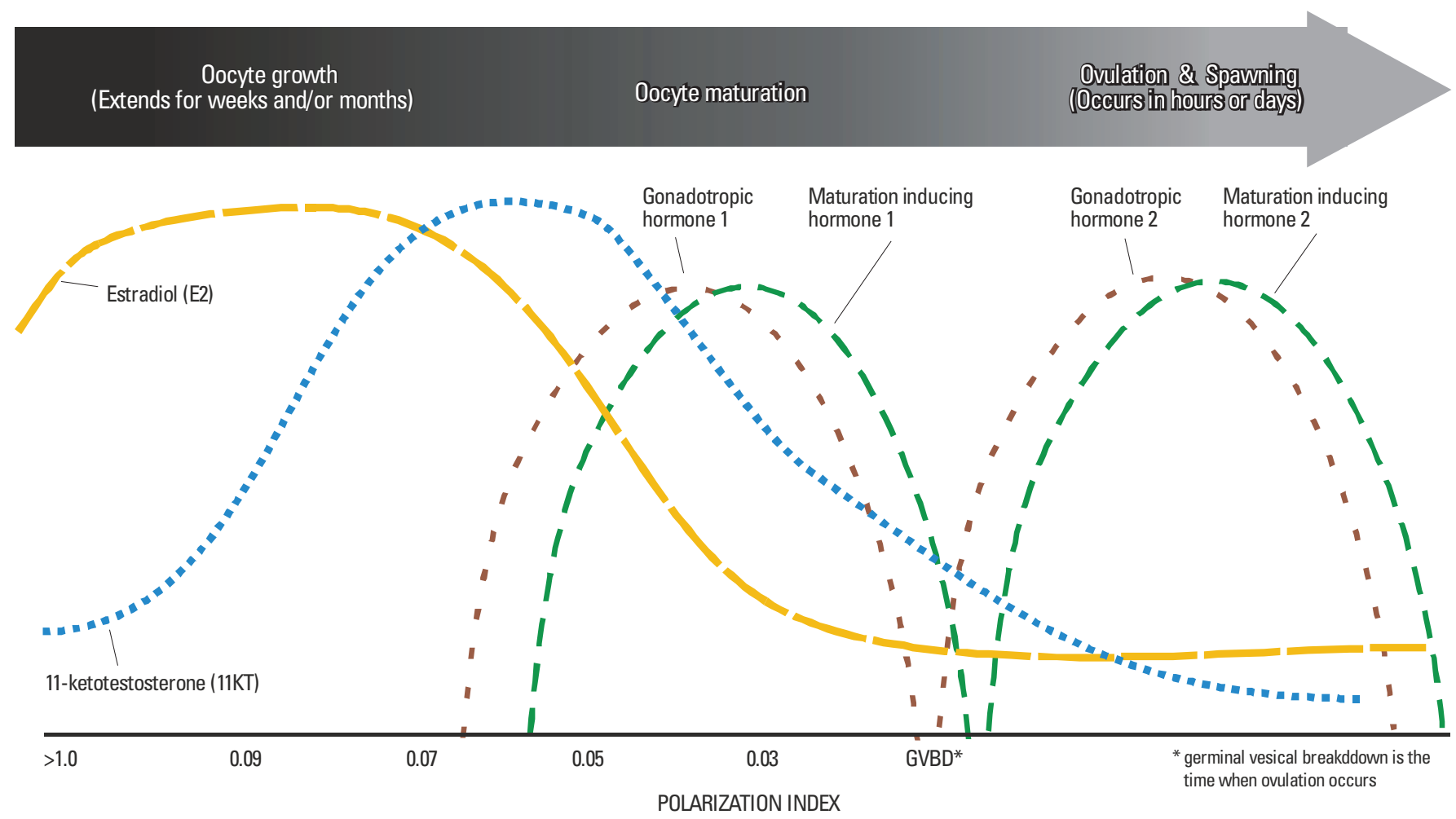

Figure 3. Conceptual model of sturgeon reproductive cycle and the expected relation between diagnostic indicators and readiness to spawn.

sturgeon require multiple seasons between spawns for gonadal development, so spawning is the culmination of a cascade of events likely controlled by environmental factors operating over the course of many months during the reproductive cycle. These factors cue the phases of the reproductive cycle so the fish are ready to spawn in spring.

We have begun to piece together those environmental factors that may be important cues using well-supported ecological theory, the innate reproductive strategy of the sturgeon, and direct observations of the behavior and physiology of the sturgeon under a variety of environmental conditions. Understanding which environmental factors and cues result in spawning is challenging because of difficulties in determining precisely when and where spawning occurs. In addition to difficulty in documenting spawning because of large depths and high turbidity, observations of fish behavior in a highly altered river may not be indicative of optimal or successful conditions.

One aspect of our approach has been to determine the fish's physiological readiness to spawn so we can more closely define when spawning should occur, and thus identify and evaluate the prevailing environmental conditions that could cue spawning during that period. A general model of physiological events preceding spawning can be applied to sturgeon and provide a conceptual model of the expected relation among diagnostic indicators and readiness to spawn (Dettlaff and others, 1993; Redding and Patino, 1993) (fig. 3). During the reproductive cycle oocytes grow, mature, are ovulated into the body cavity, and then oviposited (spawned). The changes taking place in the oocyte are reflected by the hormone levels in the parent. While the oocyte follicle is growing, estradiol (E2) is high and 11 ketotestosterone (KT) is low. Then, as the oocyte matures, E2 decreases and KT increases. As the oocytes matures in preparation for ovulation, the nucleus, or germinal vesicle $(\mathrm{GV})$, begins to move from its position in the center of the egg towards the animal pole on the outside of the egg. The polarization index (PI) is calculated as the distance from the GV to the animal pole, divided by the egg diameter. Approximately 75 percent of female sturgeon are ready to ovulate when the PI decreases to less than or equal to 0.07 . For final maturation and ovulation, a cascade of hormonal events must occur. The sequence is incompletely understood, but includes decreases in both E2 and KT and interactions of gonadotropic and maturation inducing hormones. The hormonal events are initiated after signaling from the fish's brain that conditions for spawning are appropriate.

Currently (2009), we use sex steroids E2, testosterone (T), KT, and the PI as diagnostic indicators of readiness to spawn in the laboratory and field. According to the model (fig. 3), a population of individuals that is cycling together and at a similar state of reproductive readiness should demonstrate predictable patterns with repeated sampling; as PI steadily 
decreases, E2 increases then decreases early in the season, followed by similar peaking blood concentrations of $\mathrm{T}$ and $\mathrm{KT}$ as the fish get closer to ovulation and spawning.

According to ecological theory, the relative uniformity and reliability of key environmental conditions during the spawning period will determine the types of spawning cues that are important to fishes (Wingfield and others, 1992). A predictable spawning period would result from predictable, annual environmental conditions. If the conditions are exceedingly predictable, few, if any, additional environmental cues would be necessary beyond an initial cue to initiate oocyte maturation (Cohen, 1967). Alternatively, if environmental conditions at the time of spawning are less predictable on an annual time frame, a fish would tend to rely on one or more specific environmental cues to adjust and synchronize its physiology to spawn at a time favorable to survival of its young. Environmental conditions that alter reproductive physiology will be reflected by hormonal changes in the ovary or brain (Kah and others, 2000). If environmental factors like discharge, water temperature, or day length act to support or cue spawning, then a relation between the factors and concentrations of the diagnostic hormonal indicators might be expected.

\section{Scaphirhynchus Sturgeon Spawning Behavior}

Whereas sturgeon may be anadromous, potamodromous, or amphidromous, all sturgeon species migrate upstream to spawn in fresh water (Bemis and Kynard, 1997). Final maturation of the gametes occurs during upstream movement, and migration ends with spawning near the apex, or the upstreammost location, of the fish's movement (Bemis and Kynard, 1997). The timing, distance, and duration of spawning movements vary by species. Sturgeon may migrate 10 's to 1,000 's of kilometers $(\mathrm{km})$ upstream before aggregating, spawning, and depositing their eggs, often over coarse substrate in the main channels in the upper reaches of larger rivers and streams (Auer, 1996). Spawning migrations may be rapid and of short duration, or they may occur in stages, requiring several seasons for the upstream spawning run and downstream return (Bemis and Kynard, 1997).

Reproductive shovelnose and pallid sturgeon generally move upstream beginning in the late fall and early spring and spawn in the spring and early summer (between April and July) coincident with increasing day length, increasing water temperature, and typically higher river flows (fig. 4) (Keenlyne, 1997). Timing, rate of movement, extent of migration, location of spawning sites, and the reproductive behavior of both species in the open Missouri and Mississippi Rivers remain poorly understood. Spawning runs of shovelnose sturgeon have been documented in the mainstem of the large rivers, and in both large and small tributaries (Moos, 1978; Christenson, 1975; Curtis and others, 1997). Sturgeon eggs are adhesive and spawning is assumed to occur in relatively high current velocity and turbulence over rock or coarse substrate (Kynard, 1997; Paragamian and others, 2002; McDonald and others, 2006; Fu and others, 2007). No studies have documented spawning locations or behavior of shovelnose sturgeon precisely, although spawning habitats have been inferred (Keenlyne, 1997; Kennedy and others, 2007). The reproductive behavior of pallid sturgeon is assumed to be similar to shovelnose sturgeon, although pallid sturgeon seem to be more restricted to mainstem rivers like the Mississippi and Missouri, and the lowermost reaches of large tributaries, like the Platte River, Nebraska, and Yellowstone River, Montana (Kallemeyn, 1983; DeLonay and others, 2007b).

As with most sturgeon species, habitat alteration and modification of river flows are thought to be associated with poor reproduction and insufficient survival of young shovelnose and pallid sturgeon in the Missouri River (Kallemeyn, 1983; Dryer and Sandvol, 1993; Keenlyne, 1997). These same environmental changes also may contribute substantially to reported hybridization between the two species (Hubbs, 1955; Carlson and others, 1985; Tranah and others, 2004). Whereas poor reproduction and hybridization are symptomatic of imperiled sturgeon populations in highly modified large rivers, the precise, underlying mechanisms are complex and poorly understood (Quist and others, 2004).

\section{Scaphirhynchus Sturgeon Early Life History}

Limited numbers of larval sturgeon have been collected from the Mississippi and Missouri Rivers (Hrabik and others, 2007; Hesse, 2008). Numerous factors may be responsible for limited collections, including lack of successful spawning, low recruitment, high mortality, ineffective sampling methods, inadequate sampling of drift and settling locations, or rapid dispersal of sturgeon larvae in the Missouri and Mississippi Rivers. The larval stage often can be a recruitment bottleneck for fishes because of decreased mobility and sensory ability, and increased vulnerability to anthropogenic environmental alteration (Dettlaff and others, 1993; Scheidegger and Bain, 1995; Humphries and others, 2002).

Little quantitative information is available on the freeembryo life stage of pallid and shovelnose sturgeon. Larval development and the transition between critical early life stages depend on temperature. After hatch, larval Scaphirhynchus sturgeon drift in the water column and rely on substantial yolk reserves for nutrition; yolk reserves are depleted and exogenous feeding begins after 11-12 days at 19-21 degrees Celsius $\left({ }^{\circ} \mathrm{C}\right)$ (Snyder, 2002). Initiation of feeding and yolk depletion would occur sooner at warmer temperatures, later at colder temperatures. In natural settings, shovelnose sturgeon initiate exogenous feeding at about 16 millimeters $(\mathrm{mm})$ and feed on dipterans and ephemeropterans (Braaten and Fuller, 2007). After hatching, larval pallid sturgeon drift for 11-17 days (Kynard and others, 2007; Braaten and others, 2008), and shovelnose sturgeon drift for up to 6 days (Braaten and others, 2008). The total distance that sturgeon larvae drift during ontogenetic development is dependent on water velocity and temperature (Kynard and others, 2007; Braaten and others, 


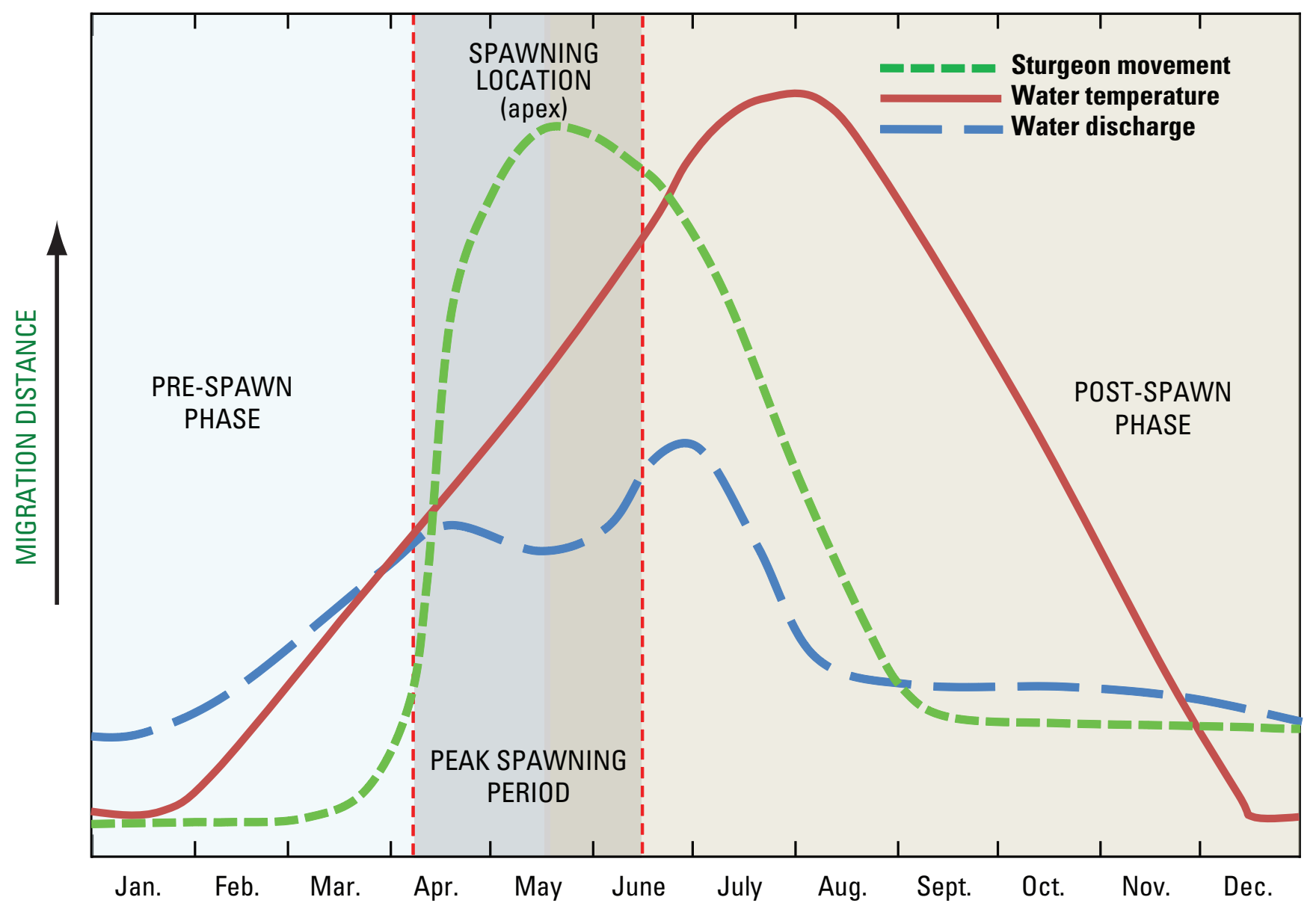

Figure 4. Conceptual model of Scaphirhynchus sturgeon spawning migration and behavior in the Lower Missouri River.

2008). The prolonged drift period of larval sturgeon and the prevailing Missouri River velocities may require a long stretch of free-flowing river to complete the ontogenetic drift cycle. Larvae that drift into the headwaters of reservoirs probably do not survive (Jager and others, 2002). Initiation of feeding on or about day 10, coupled with the finding that sturgeon start using benthic habitats on or about day 8 , suggests occupation of benthic habitats is related to food availability (Dettlaff and others, 1993).

The stage when larval fishes begin feeding is often called the "critical period" because they are highly susceptible to mortality if food of the proper size and nutritional value is not available within a short time period (Gisbert and Williot, 2007; Deng and others, 2003; Gisbert and Doroshov, 2003). Lack of food during the transition period from endogenous to exogenous feeding has deleterious effects on the sturgeon digestive tract that may diminish growth and survival (Gisbert and Doroshov, 2003; Gisbert and Williot, 2007). Similarly, restricted availability and limited intake of food during the first-feeding life stage may suppress growth (Deng and others, 2003).

Predation and competition also must be low for larvae to survive to the juvenile life stage. The small size of feeding larval sturgeon makes them particularly susceptible to mortality from predation. Water clarity of the Lower Missouri River has increased since impoundment and may have increased predation risk to small sturgeons that historically relied on the river's high turbidity as cover from sight-feeding piscivorous fishes such as sauger (Sander canadensis), goldeye (Hiodon alosoides), walleye (Sander vitreus vitreus), and smallmouth bass (Micropterus dolomieu) (Hesse and others, 1989). Furthermore, each sturgeon species encounters intra- and interspecies competition at each life stage because of the number of benthic species present in the Missouri River (Berry and Young, 2004), all of which may be competing directly with sturgeon larvae for food resources. Competition for space and resources may continue as larvae develop into juvenile life stages. Juvenile pallid and shovelnose sturgeon use the same habitat during non-winter creating the potential for competition among species (Gerrity and others, 2008). Recent research indicates that white sturgeon overwintering areas contain high densities of sturgeon, indicating the potential for seasonal intra- and interspecific competition for habitat resources (Golder Associates, 2006). 


\section{Missouri River Background}

Reproductive strategies of the pallid sturgeon evolved within the physical context of the historical range in the Mississippi River Basin, yet efforts to recover the species must take place within the system as it was altered for socioeconomic benefits. Understanding of spatial variability and temporal dynamics of the Missouri River system is essential for understanding the reproductive strategy of the species, and the constraints imposed by the alteration. In the natural system, highly variable geology and strong climatic gradients contributed to high variability in the flow regime and channel morphology of the Missouri River. Dams and channel engineering present additional punctuated variation along the river, including barriers to migration.

The CSRP focuses on the Lower Missouri River, defined as the part of the river downstream from Gavins Point Dam, Nebraska, extending to the confluence of the Mississippi River near St. Louis, Missouri (fig. 1). These boundaries serve to narrow our research efforts, although we gain insights from related sturgeon studies in the upper Missouri and Yellowstone Rivers, inter-reservoir reaches of the Missouri River, and the Middle and Lower Mississippi River. Studies on the Middle Mississippi River are especially relevant to understanding Lower Missouri River pallid sturgeon because of evidence that sturgeon migrate between the two systems (Garvey and others, 2009). The following sections discuss the physical context of the Lower Missouri River and the specific hydroclimatic conditions existing during studies conducted from 2005 to 2008. Throughout the report, terminology is used to denote geographically distinct lengths of the river. Segments are defined as physically distinct lengths of the mainstem bounded by major tributaries or geologic or engineering boundaries that substantially affect flow regime or channel morphology. Section is used to denote lengths of the Missouri River mainstem encompassing multiple segments.

\section{Physical Context of Missouri River}

Exceeding 4,000 km long, the mainstem Missouri River is the Nation's longest river. At St. Louis, Missouri, it drains a basin that exceeds 1,300,000 square kilometers $\left(\mathrm{km}^{2}\right)$ in area (Galat and others, 2005), and extends from the Mississippi River on the east to the crest of the Rocky Mountains to the west, and from the Ozark Plateaus in the south to the northern Great Plains (fig. 1). The large hydrologic and geologic variation that exists within the Missouri River basin historically offered a template of highly variable physical habitats available to migrating sturgeon.

The Missouri River Basin mixes snow-melt hydrology in the Rocky Mountains and Great Plains with less predictable runoff from frontal storms and tropical air masses from the Gulf of Mexico. This leads to a characteristic double-peaked annual hydrograph, with March and May-June flood pulses, and naturally increasing flow variability moving downstream (Galat and Lipkin, 2000; Pegg and others, 2003).

As the Missouri River flows from the Rocky Mountains through the Great Plains, it traverses a broad area dominated by annual precipitation ranging from 200 to $500 \mathrm{~mm}$, a precipitation range that generally results in maximum unitarea sediment delivery rates (Langbein and Schumm, 1958). Sediment contributions from the Great Plains are responsible for the Missouri River's large natural sediment flux (Jacobson and others, 2009a) and dominance of the Mississippi River's sediment load (Meade, 1995).

Bedrock and surficial geology also directly affect physical aquatic habitats in the river corridor. Near Yankton, South Dakota, the Missouri River flows across the southern boundary of the Wisconsin glaciation (King and Beikman, 1974). Upstream from Yankton, gravel-cobble deposits of glacial origin are relatively common and may have provided suitable spawning substrate for sturgeon before construction of Gavins Point Dam. Downstream from Yankton, the river flows near the margin of pre-Wisconsin glaciers; however, because as many as 540,000 years have passed since glacial drift was deposited in the valley, the sediments have been mostly eroded from the river corridor (Langer and others, 2002; Laustrup and others, 2007). Coarse, particulate deposits do not become common again until the river cuts through the Ozarks Plateau in Missouri, where north-flowing tributaries deliver chert gravel to the river (Laustrup and others, 2007).

Extensive deposits of late Pleistocene outwash underlie a broad alluvial valley extending from Yankton, South Dakota, to near Glasgow, Missouri (fig. 1). Downstream from Glasgow, the valley narrows from $8-12 \mathrm{~km}$ to $3-4 \mathrm{~km}$ as the river cuts through sedimentary rocks of the Ozarks Plateau. This abrupt change in valley character has been attributed to a significant change in river alignment during the Pleistocene (Heim and Howe, 1963; Galloway, 2005); the narrow valley has the potential for substantially different aquatic habitat because of frequent interaction between the channel and bedrock bluffs.

\section{Research Approach}

Progress in understanding reproduction and survival of a rare fish in a large river has required development of new approaches and new technology. In the CSRP, we have applied biological, ecological, chemical, and physical scientific expertise to address the challenging questions of how multiple stressors may affect reproduction and survival of the pallid sturgeon. We have collaborated with Federal and State agencies to overcome the logistical challenges of studying the fish over thousands of kilometers of the Missouri River, and we have combined opportunistic field studies, field-based experiments, and controlled laboratory studies into a portfolio of approaches that provides new perspectives on sturgeon reproductive ecology. 
Specific technical innovations have been necessary to make progress in understanding sturgeon ecology. Progress has been particularly dependent on the following.

- Methods for understanding fish behavioral patterns through telemetry, archival data tags, and deployment of acoustic imaging technology have been essential to understand where, when, and how sturgeon use the Lower Missouri River (DeLonay and others, 2007a; DeLonay and others, 2007b). In addition to implementing an acoustic telemetry project of unprecedented scale, we have developed innovative approaches to computerized data collection platforms, database management, analysis, visualization, and reporting of extensive telemetry datasets (DeLonay and others, 2007b).

- Trotline, gill net, and drifted trammel net modifications have led to increased safety and efficiency in capturing adult pallid sturgeon for telemetry studies and broodstock for propagation (DeLonay and others, 2007b). Specialized gear type effectiveness has been further enhanced through an informed-sampling strategy that uses telemetry data to identify frequently used habitats and to target individual sturgeon for recapture.

- Methods for assessing reproductive readiness of fish in the laboratory, hatchery, and field using imaging (ultrasound and endoscopy), egg development, and blood chemistry have provided new insights into sturgeon reproductive physiology (Wildhaber and others, 2005; Bryan and others, 2007; DeLonay and others, 2007b; Wildhaber and others, 2007b).

- Methods for sampling larval sturgeon and assessing drift rate and cumulative distance drifted by larval sturgeon have substantially altered understanding of where and how fast sturgeon larvae drift (Braaten and others, 2008; P.J. Braaten, U.S.Geological Survey, written commun., 2009).

- Methods for measuring and modeling river habitat dynamics using state-of-the-art hydroacoustics, and innovative approaches to quantifying habitat variables have vastly improved how habitats are quantified on large, sand-bed rivers (Gaeuman and Jacobson, 2005; 2006; 2007a; 2007b; Jacobson and others, 2007; Reuter and others, 2008; Elliott and others, 2009; Jacobson and others, 2009b).

- Methods for integrating understanding of sturgeon through individual and population modeling have provided a basis for identifying critical life stages, additional information about Missouri River sturgeon populations numbers and distribution, and key information gaps for resource managers (Whiteman and others, 2004; Bajer and Wildhaber, 2007; Wildhaber and others, 2007b; Arab and others, 2008).
Although new technology, innovation, and interdisciplinary integration have been important for improving scientific understanding of pallid sturgeon reproductive ecology, substantive challenges persist because of the inherent difficulties of working with a rare species in a large, muddy river. Innovative technology will continue to provide new and important insights, but well-documented understanding may still require many years of observations to define reproductive requirements and to provide information sufficient to support management decisions.

The following sections present the CSRP research approach, including the field research framework, use of the shovelnose sturgeon as a comparative model, and specific methods applied to study types. In this report, the discussion of research methods is abbreviated because most of the information is available in other published reports.

\section{Field Research Framework}

The CSRP was designed to include an evaluation of the role of flow regime and associated environmental cues using two complementary approaches to address hydroclimatic variation in the Lower Missouri River. An upstream-downstream approach compares sturgeon reproductive behavior between two river sections that differ markedly in hydrology and channel morphology. The upstream section has an altered flow regime because of proximity to Gavins Point Dam, whereas the downstream section maintains much of its pre-regulation variability. On average, flow pulses in the downstream section occur multiple times per year and are of substantially longer duration and larger magnitude.

The upstream section also has the potential for an experimental approach to compare reproductive behavior in years with pulsed flow modifications to years without modifications (U.S. Army Corps of Engineers, 2006; Jacobson, 2008; Jacobson and Galat, 2008). Flow pulses are expected to be released from Gavins Point Dam approximately once every 3 years on average (U.S. Fish and Wildlife Service, 2000; 2003) and range in size up to 12,000 cubic feet per second $\left(\mathrm{ft}^{3} / \mathrm{s}\right)$ above prevailing navigation discharges (U.S. Army Corps of Engineers, 2006). Each year there is an opportunity to compare upstream and downstream responses to flow pulses, although the downstream section will lack the control on timing and magnitude of the pulses afforded by manipulated releases in the upstream section.

The combined design provides opportunity to examine environmental controls on temporal and spatial patterns of spawning behavior, habitat use and availability, reproductive physiology, and larval drift for shovelnose and pallid sturgeon. Habitat use and availability data derived from detailed telemetry and hydroacoustic mapping enable a combined use of exploratory, discrete-choice, and utilization distribution modeling (Millspaugh and Marzluff, 2001) to describe fish habitat selection throughout the spawning season. Using a combination of uni- and multivariate classical parametric 
statistics, functional time series analyses, and hierarchical Bayesian approaches on the data storage tags (DST), physiology, telemetry, and drift data, we can assess predictor and explanatory variables (both environmental and physiological) potentially indicative of spawning behavior, successful spawning, and larval drift. Results from this research framework are amenable to statistical modeling to identify and rank proximate cues necessary for successful spawning by Missouri River sturgeon.

Field research approaches can be affected by prevailing hydroclimatic conditions, as documented in the following section of this report. The size and frequency of pulsed flow modification releases allowed from Gavins Point Dam depend on criteria enumerated in the Missouri River Master Manual (U.S. Army Corps of Engineers, 2006). Pulsed flow modifications are precluded or prorated below specific volumes of system storage; pulses also are precluded if downstream flow limits are exceeded. In addition to variation programmed in the Master Manual, tributaries downstream from Gavins Point Dam can produce uncontrolled flows that deviate from the ideal experiment. For example, years without planned pulsed flow modifications are essential controls for flow-modification experiments, but flooding from uncontrolled tributaries like the James River (22 km downstream from Gavins Point Dam), Vermillion River (63 km downstream from Gavins Point Dam), and the Big Sioux River (124 km downstream from Gavins Point Dam) can produce substantial flow pulses. Similarly, year-to-year climatic variation in the Grand, Chariton, Osage, and Gasconade River Basins can produce a wide range of unpredictable flow pulses in the downstream segments.

The water-temperature regime also varies along the Lower Missouri River, presenting another uncontrolled variable in field studies. Water temperatures vary systematically on an annual timescale, peaking in late July to early August, and downstream temperatures typically are $2-5^{\circ} \mathrm{C}$ warmer than upstream temperatures during the summer. Short-term variation of water temperatures may be affected by the temperature of water released from Gavins Point Dam (and other dams in the Missouri River Basin), heating or cooling of the channel through direct heat exchange with the atmosphere, and indirect heating or cooling through mixing with tributary flows. The interaction of these factors can be complex, and their relative affects on temperature likely vary along the river and by season. These interactions have not been well characterized along the Lower Missouri River; initial data in this report illustrate that water-temperature can vary independently from discharge under some conditions.

\section{Hydroclimatic Conditions 2005-08}

The hydroclimatic setting for sturgeon studies during 2005-08 included the effects of extended drought in the Missouri River system (fig. 5). From 2004-08, the system experienced storage levels that were the lowest since the reservoir system was filled in 1967. As a result, conditions in 2006-08 only were marginally conducive for flow modifications. In 2006 , the threshold amount of water storage in the system necessary for a pulsed flow release (drought preclude) was not available in March, but it was available in May; consequently, a $9,000 \mathrm{ft}^{3} / \mathrm{s}$ pulse was released during May (fig. 6).

In 2007, system storage was insufficient for either March or May pulses, so no pulsed flows were released from Gavins Point Dam. Nevertheless, floods from the James, Vermillion, and Big Sioux Rivers (fig. 1) contributed substantial spring flow pulses between Gavins Point Dam and Sioux City, Iowa resulting in increased discharges at locations along the mainstem Missouri River in 2007 (fig. 6). The James River had a $19,600 \mathrm{ft}^{3} / \mathrm{s}$ pulse $5 / 11 / 2007$, with an estimated 21 -year return interval. The Vermillion River produced 3 pulses of 1,700 $2,500 \mathrm{ft}^{3} / \mathrm{s}$ from early April to mid May. The Big Sioux River produced a $23,000 \mathrm{ft}^{3} / \mathrm{s}$ pulse $3 / 16 / 2007$ and a $11,500 \mathrm{ft}^{3} / \mathrm{s}$ pulse 4/3/2007; the first pulse has an estimated return interval of 5 years and the second of 2 years.

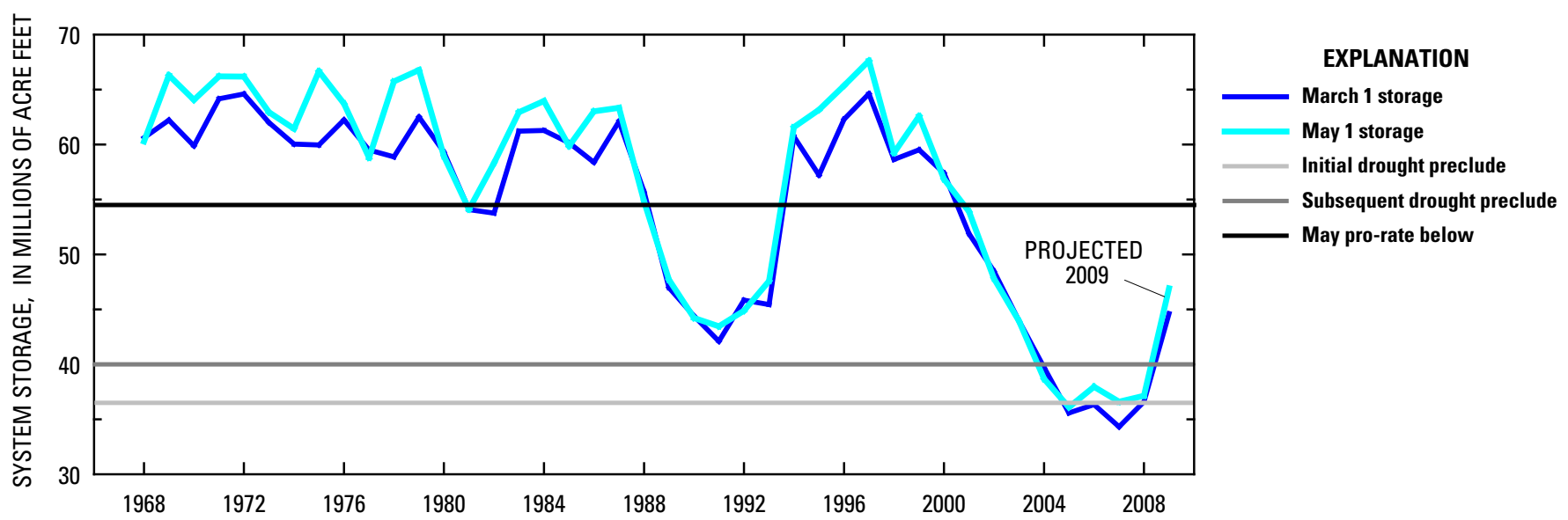

Figure 5. Missouri River reservoir system storage on March 1 and May 1, 1967-2009, compared to drought precludes (limits below which pulsed-flow modifications are not attempted) and the storage threshold below which pulses may be decreased on a pro-rated basis (U.S. Army Corps of Engineers, 2006). Projections from 2009 are median runoff forecasts (U.S. Army Corps of Engineers, 2008). 

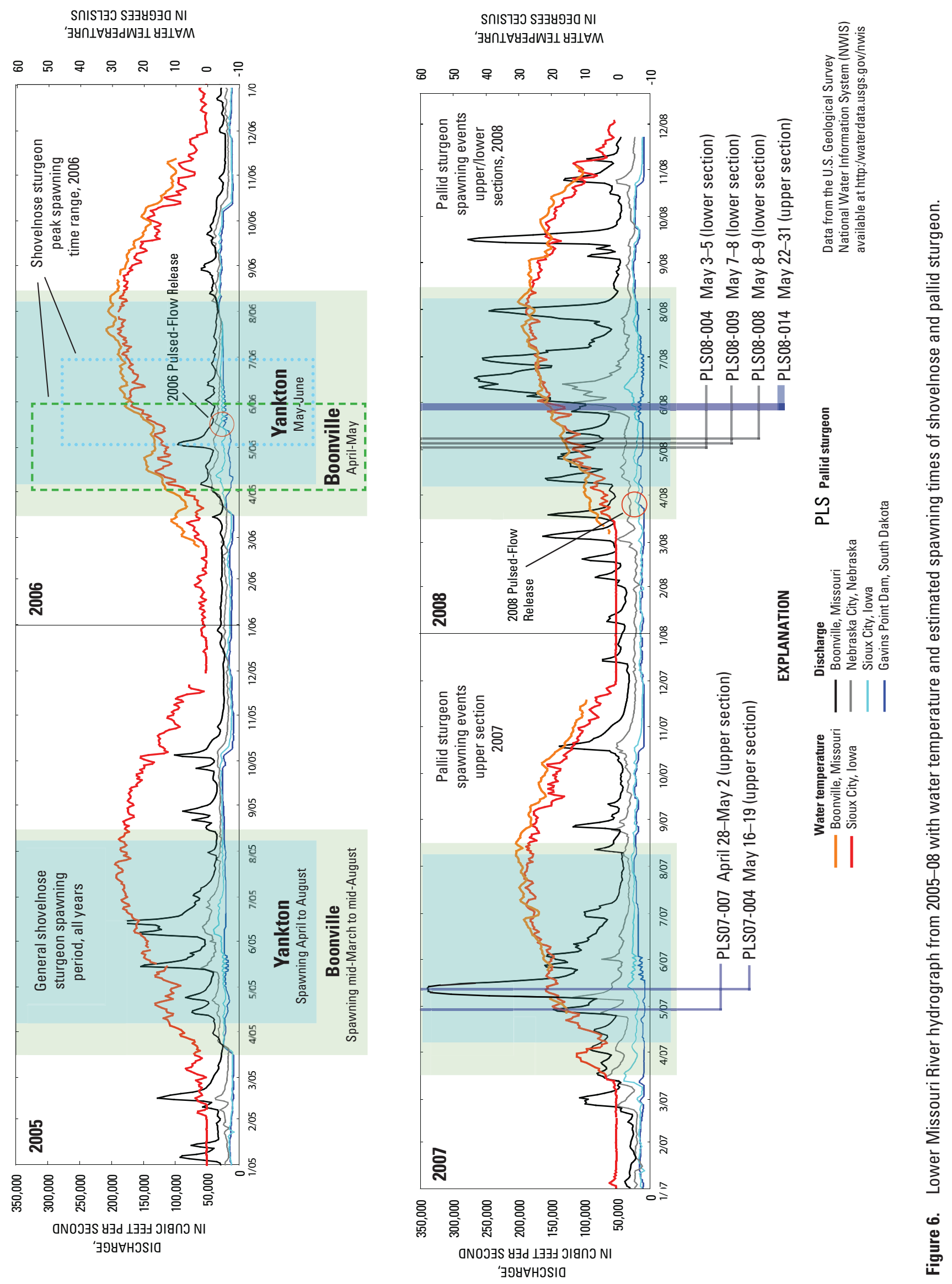
Table 1. Mean annual discharge at Sioux City, lowa, and Boonville, Missouri, 1967-2008, with mean daily discharge and annual exceedances for 2005-08.

$\left[\mathrm{ft}^{3} / \mathrm{s}\right.$, cubic feet per second; $\%$, percent]

\begin{tabular}{|c|c|c|c|c|c|c|c|c|c|}
\hline \multirow[b]{2}{*}{$\begin{array}{l}\text { U.S. Geological } \\
\text { Survey stream- } \\
\text { flow gaging } \\
\text { station name } \\
\text { and number }\end{array}$} & \multirow[b]{2}{*}{$\begin{array}{c}\text { Mean } \\
\text { annual } \\
\text { discharge } \\
\left(\mathrm{ft}^{3} / \mathbf{s}\right)\end{array}$} & \multicolumn{2}{|c|}{2005} & \multicolumn{2}{|c|}{2006} & \multicolumn{2}{|c|}{2007} & \multicolumn{2}{|c|}{2008} \\
\hline & & $\begin{array}{c}\text { Mean } \\
\text { daily } \\
\text { discharge } \\
\left(\mathrm{ft}^{3} / \mathrm{s}\right)\end{array}$ & $\begin{array}{c}\text { Annual } \\
\text { ex- } \\
\text { ceedance } \\
(\%)\end{array}$ & $\begin{array}{c}\text { Mean } \\
\text { daily } \\
\text { discharge } \\
\left(\mathrm{ft}^{3} / \mathbf{s}\right)\end{array}$ & $\begin{array}{c}\text { Annual } \\
\text { exceed- } \\
\text { ance } \\
(\%)\end{array}$ & $\begin{array}{c}\text { Mean } \\
\text { daily } \\
\text { discharge } \\
\left(\mathrm{ft}^{3} / \mathrm{s}\right)\end{array}$ & $\begin{array}{c}\text { Annual } \\
\text { exceed- } \\
\text { ance } \\
(\%)\end{array}$ & $\begin{array}{c}\text { Mean } \\
\text { daily } \\
\text { discharge } \\
\left(\mathrm{ft}^{3} / \mathrm{s}\right)\end{array}$ & $\begin{array}{c}\text { Annual } \\
\text { exceed- } \\
\text { ance } \\
(\%)\end{array}$ \\
\hline $\begin{array}{c}\text { Sioux City, Iowa } \\
06486000\end{array}$ & 30,800 & 20,360 & 95 & 21,920 & 85 & 20,110 & 98 & 18,820 & 100 \\
\hline $\begin{array}{c}\text { Boonville, Mo. } \\
06909000\end{array}$ & 67,000 & 50,230 & 76 & 36,880 & 100 & 62,030 & 51 & 82,798 & 29 \\
\hline
\end{tabular}

In 2008, March system storage was sufficient for a 5,000$\mathrm{ft}^{3} / \mathrm{s}$ pulsed flow release on 3/23-3/26/2008 (fig. 6); however, storage was insufficient to support a May pulse.

Upstream and downstream hydroclimatic conditions often were different during 2005-08. Year-to-year variation in discharge was high, particularly in the downstream section (fig. 6; table 1). The mean daily flow at Boonville in 2005 was equaled or exceeded 76 percent of the years since 1967 , the year the reservoirs were full and began to be operated as a system. In 2006 mean daily flow at Boonville was the lowest on record with 100 percent exceedance, and in 2007 and 2008, mean daily flows were 51 and 29 percent exceedance. The wettest year in the upstream section ( 85 percent flow exceedance at Sioux City) occurred during 2006, the driest year at Boonville, and the driest year at Sioux City (100 percent exceedance in 2008) occurred during the wettest year measured at Boonville.

The complexity of hydroclimatic variation observed during these four years makes it challenging to isolate reproductive behavioral responses to specific pulses. Nevertheless, the wide range of magnitude, duration, and timing of high- and low-flow events encountered during this time assures that this study assessed a wide range of hydrologic drivers.

\section{Shovelnose Sturgeon Models}

The CSRP has made extensive use of shovelnose sturgeon as a model for understanding pallid sturgeon reproductive ecology and physiology. Despite evidence of substantial decline, the shovelnose sturgeon (S. platorynchus) remains relatively common in the Lower Missouri and Mississippi Rivers (Becker, 1983). Its persistence and resiliency compared to the larger pallid sturgeon may be because of its earlier maturity, lower trophic status, and adaptability to a broader range of environmental conditions (Keenlyne and Jenkins, 1993). Both sturgeon species are adapted to large, turbid, riverine environments; however, pallid sturgeon do not appear to use the minor tributaries or clear-water riverine habitats frequented by shovelnose sturgeon, and do not persist in the short reaches of river between dams and reservoirs (Mayden and Kuhajda, 1997). Moreover, pallid sturgeon become piscivorous after 3-5 years of age, whereas the shovelnose sturgeon subsists primarily on invertebrates (Modde and Schmulbach, 1977; Carlson and others, 1985; Keenlyne, 1997). Nevertheless, the morphological and genetic similarities clearly indicate that these two sympatric species are closely related (Bailey and Cross, 1954; Campton and others, 2000; Simons and others, 2001; Snyder, 2002). Consequently, the shovelnose sturgeon offers opportunities to develop and test physiological indicators and reproductive assessment tools that may be applicable to pallid sturgeon. Understanding the reproductive ecology of shovelnose sturgeon also contributes to a weight-of-evidence approach to understanding reproductive ecology of pallid sturgeon.

\section{Reproductive Physiology}

Photoperiod, water temperature, and in some environments, discharge are the primary factors thought to cue the reproductive physiology of most fishes (Lam, 1983). Physiological and morphological measurements allow scientists to evaluate the direct biological responses of sturgeon to environmental conditions. Responses may be general, such as stress, or may be specific, such as indicating how close a sturgeon is to ovulation. Our approach was to assess the reproductive condition of sturgeon before their spawning migration, regularly during their migration, and then again upon recapture (as soon after spawning as possible) and relate the readiness to spawn and success in spawning to location, discharge, water temperature, and day length. Fish were collected in both sections of the river to allow for comparisons of the different effects of temperature and discharge on spawning. Limited additional fish samples were collected in 2005 from the Yellowstone River and from the Wabash River in 2007 as a proof of 
concept of the relations among upstream migration, temperature, and physiological indicators.

Readiness to spawn was assessed by using the PI, the progesterone assay, and blood reproductive hormones (Dettlaff and others, 1993; Wildhaber and others, 2007b). Spawning success was evaluated based on visual and microscopic inspection of gonads and blood reproductive hormones (Wildhaber and others, 2007b). As a gravid female progresses towards spawning, the germinal vesicle (GV) of the oocyte gets closer to the animal pole. Sometime during the migration of the GV to the animal pole (generally estimated as a PI of $<0.07$ ), the hormonal system is cued that ovulation may proceed. The fish has reached maturational competence at this time. When conditions are suitable, the final stages of maturation commence such that specific hormones (luteinizing hormone and maturation-inducing hormone) are released, causing germinal vesicle breakdown (GVBD) followed by ovulation. The concentrations of sex hormones also change during the course of migration, final maturation, ovulation, and spawning. Estrogen and testosterone typically are high when migration begins and decrease at different rates through spawning. Additionally, some hormones, such as cortisol, reflect the degree of stress the fish is experiencing, and their increase has been correlated with changes in sex hormone levels and failure to spawn. We measured cortisol in most blood samples collected in these studies; however, interpretation of the values has been difficult because reference values have been lacking. Therefore, an additional set of laboratory experiments were designed in 2006 to provide basal (low) and stressed (high) reference values of cortisol for comparison to values obtained in studies.

\section{Movement and Behavior}

We used both pallid and shovelnose sturgeon to study spawning migration and behavior. The shovelnose sturgeon provided abundant numbers of individuals for telemetry studies, and information derived from the shovelnose sturgeon provide a model that can be compared and contrasted with more limited observations available for the much less abundant pallid sturgeon.

Telemetry transmitters were implanted surgically in captured sturgeon to develop a geographic understanding of fish migration and habitat usage. Telemetry transmitters were complemented with data storage tags (DST) that use embedded sensors to record depth (as pressure) and temperature. The combination of tags was used to track fish in known reproductive condition and to record individually-based, behaviorallydirected observations of location, movement, and habitat use (DeLonay and others, 2007a; DeLonay and others, 2007b). Our strategy was to follow the fish, and allow the fish, and the implanted sensors it carries, to convey critical information about the habitats and conditions it requires to feed, grow, and reproduce. Fish were evaluated for reproductive readiness during implantation procedures using minimally invasive imaging tools and blood serum chemistry (see previous section). Sturgeon were tracked in the Lower Missouri and Middle Mississippi Rivers using specially designed research vessels equipped with mobile, geo-referenced data-collection systems (DeLonay and others, 2007b). Fish were targeted for recapture during the post-spawn phase to determine whether or not the individual had spawned and to recover the DSTs. Telemetrytagged fish are effectively and consistently recaptured by precisely drifting large mesh trammel nets $(7.6 \mathrm{~cm}$ x $40.6 \mathrm{~cm}$ bar mesh) over the fish's location.

From 2005 to 2008, the locations and species emphasized varied as the CSRP adjusted to variable funding and directions provided by the U.S. Army Corps of Engineers (table 2). Studies in 2005 and 2006 focused on reproductive female shovelnose sturgeon in upstream and downstream study sections. Fish were captured and implanted between the Platte River, Nebraska, and the Big Sioux River, Iowa (river mile 595-734), in the upper study section (fig. 1). Fish in the lower study section were collected approximately between the Osage River, Missouri, and the Grand River, Missouri (river mile 130-250) (fig. 1). Pallid sturgeon were included opportunistically, when and where possible; however, numbers of pallid sturgeon were limited, and U.S. Fish and Wildlife Service species-recovery priorities resulted in all reproductively ready pallid sturgeon adults being transferred to hatcheries for inclusion in the propagation program.

Studies in 2007 focused only on the upper study section in a year without a planned spring pulse from Gavins Point Dam. Although appropriate reference conditions in highly altered systems are difficult to define, working in the upstream section provided an opportunity to study the response of shovelnose and pallid sturgeon in the 216 river miles immediately downstream from Gavins Point Dam to the Platte River, Nebraska, in the absence of a managed pulse flow. The uppermost 59 river miles have the least altered channel morphology that exists in the Lower Missouri River (Elliott and Jacobson, 2006). Studies in 2007 included an extensive tracking study of large numbers of reproductive female and male shovelnose sturgeon, as well as non-reproductive individuals implanted in two areas (river mile 648-685 and river mile 727-756) within the upper study section. As a companion to the shovelnose study, an intensive tracking study with a small number of reproductive pallid sturgeon also was conducted.

In 2008, we expanded the intensive pallid sturgeon tracking study to include the upper and lower study sections. The emphasis transitioned from shovelnose sturgeon to an exclusive focus on movement, habitat use, and behavior of reproductive and non-reproductive adult pallid sturgeon.

\section{Early Life History}

For early life history studies, we partitioned the Lower Missouri River between Gavins Point Dam and river mile 590 into five subsegments based on locations of tributary confluences with mean annual discharge greater than $350 \mathrm{ft}^{3} / \mathrm{s}$, 


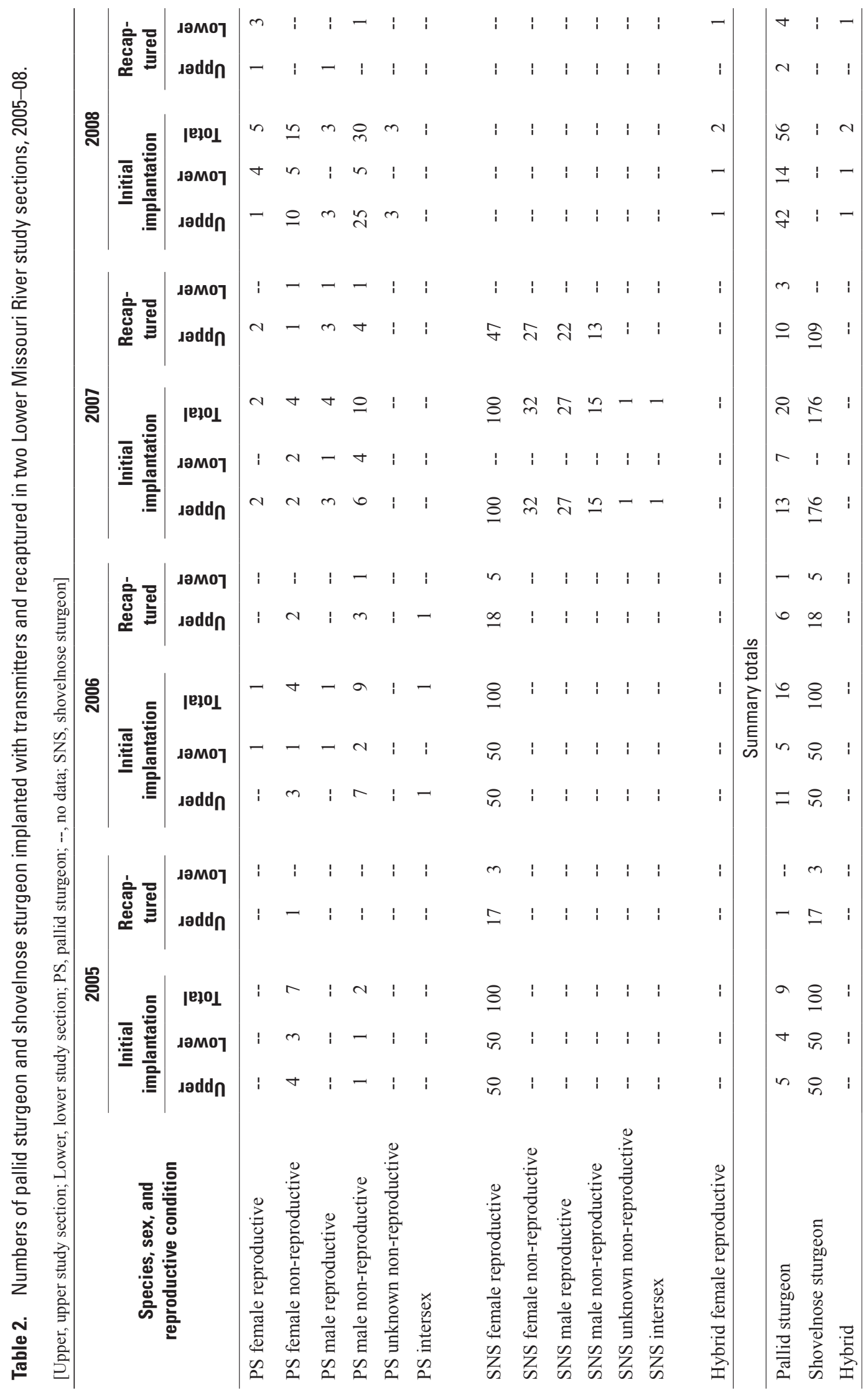


following Braaten and Guy (2002). Use of this finer segmentation of the Missouri River mainstem was intended to resolve hypothesized hydrologic effects of medium-sized tributaries on early life history. These subsegments were delimited at the James River, Vermillion River, Big Sioux River, Little Sioux River, and Platte River, all within the broader study's upstream section. Drifting larval fishes were sampled with conical plankton nets [750-micrometer $(\mu \mathrm{m})$ mesh] two times per week at fixed sites within river segments from March 8, 2006 through August 8, 2006 and May 2, 2007 through August 10,2007 . In 2007, sampling also occurred in each of the major tributaries (Simpkins and LaBay, 2007). Larval fish were separated from debris and identified to genus using published morphological descriptions and dichotomous keys (Snyder, 1980; Auer, 1982; Wallus, 1990; Snyder, 2002).

\section{Habitat Assessments}

Habitats were assessed to improve understanding of how physical and chemical habitat may limit reproduction and survival of sturgeon. Assessments included the spatial distribution of habitats, habitat changes with time, and habitat selection by sturgeon during adult life stages. Habitat assessments can be classified into habitat dynamics (variations in habitat with time as a result of varying discharge and sediment transport), habitat availability (measures of habitat that are available to a fish, integrated for appropriate time scales), and habitat selection (measures of habitat selected from the range of habitats available).

\section{Habitat Dynamics}

Intensive evaluations of habitat dynamics were completed in four reaches of the Missouri River at Miami, Missouri (river mile 259.6-263.5), Little Sioux, Iowa (river mile 669.6673.5), Kenslers Bend, Nebraska (river mile 743.9-748.1), and Yankton, South Dakota reach (river mile 804.8-808.4) (fig. 1). These reaches were selected because they are broadly representative of the range of channel morphology existing in the Lower Missouri River. In addition, three of the four reaches were identified as probable spawning reaches because they were apices of shovelnose sturgeon migrations in a related study in 2005 (DeLonay and others, 2007b). The fourth reach (at Yankton, South Dakota) was selected because it contains a large, natural gravel-cobble deposit thought to be the best example of natural spawning substrate on the Lower Missouri River (Laustrup and others, 2007). Hydrodynamic modeling of habitat was used to systematically explore how habitat metrics change with discharge, and to assess sensitivity of habitats to flows envisioned for spring pulse-flow modifications (Jacobson and others, 2009b). Monitoring of channel cross sections and indicators of sediment transport in the four reaches during the 2-year study was used to assess background rates of geomorphic temporal variability and sensitivity of sed- iment transport to potential pulse-flow modifications (Elliott and others, 2009; Jacobson and others, 2009b).

\section{Habitat Availability}

In a more extensive approach, we documented habitat availability by hydroacoustic mapping of reaches of the Missouri River in association with telemetric sturgeon locations. The datasets and methods are documented in Reuter and others (2008). The study design involved mapping depth, velocity, and substrate characteristics in river reaches to assess habitat use and availability. The dataset includes 153 reaches averaging $2.4 \mathrm{~km}$ long, and incorporates 378 sturgeon locations. In addition to primary measurements of depth, velocity, and substrate characteristics, derivative habitat metrics included bottom slope, velocity gradient (spatial variation in velocity), and Froude number (a dimensionless number relating velocity to the square root of depth times the gravitational constant).

\section{Habitat Selection}

We used quantitative understanding of how adult sturgeon distribute themselves within the Missouri River to infer which habitats are most supportive of sturgeon during the adult life stage. Because of the extensive alteration of the Lower Missouri River channel morphology, habitats used by sturgeon may document the best available habitat, rather than optimal or preferred habitats.

We evaluated habitat selection by comparing adult, female gravid sturgeon locations to habitat available in the surrounding reach. An exploratory analysis phase documented broad measures of habitat selection and avoidance using Ivlev's selectivity coefficients (Reuter and others, 2009). This was followed by a more detailed assessment of a part of the data set in which we evaluated habitat selection using discrete choice models (Cooper and Millspaugh, 1999; 2001) within an information theoretic approach. The latter analysis identified whether or not selection for habitat characteristics was associated with specific directions and distances from fish. By comparing habitat selection models and their validation performances across years and river sections, we assessed the amount of longitudinal and temporal variation in sturgeon use of the river (T.W. Bonnot, University of Missouri, written commun., 2009).

\section{Results}

The following sections present results of the CSRP research during 2005-08, organized by specific approach: reproductive physiology; movement and behavior; early life history; and habitat dynamics, availability, and selection. 


\section{Reproductive Physiology}

Measurements of reproductive indicators provide time series of reproductive conditions that may be compared with time series of potential environmental spawning cues, and thereby indicate whether or not there are cause-and-effect links between the two. The following section presents the results of this analysis, followed by ancillary information on reproductive abnormalities of Missouri River sturgeon present during the course of these studies.

\section{Matching Patterns to Discern Spawning Cues}

Similar results from a population of gravid shovelnose sturgeon that were followed up the Yellowstone River in 2005 and for a population of gravid shovelnose from the Wabash River in 2007 confirm the salient features of the reproductive physiology conceptual model (fig. 7). These results demonstrate that physiological indicators systematically document reproductive progression of sturgeon and may, therefore, serve to identify the environmental conditions required by sturgeon for initiation and completion of the reproductive cycle.

Reproductive assessments of Missouri River shovelnose sturgeon in upstream and downstream sections during four seasons from 2005 to 2008, document consistent, predictable spawning windows (fig. 6). Our field observations indicate that black-egged Missouri River sturgeon captured in March with PIs equal to or less than $(\leq) 0.30$ can spawn during that same year, and our laboratory experiments have determined that the eggs of more than 75 percent of females are ready to be fertilized, if spawned, when PI is $\leq 0.07$. We analyzed data from fish collections to determine the degree of predictability of the annual pattern of the presence or absence of reproductively ready sturgeon (fish with PI $<0.07$ ). Using this latter criterion, Colwell's (1974) constancy/contingency model of predictability indicates that the presence of fish physiologically capable of spawning is a predictable event in the Missouri River. The value for predictability $(\mathrm{Pr})$ can vary between zero (minimally predictable) and one (maximally predictable) and is composed of the sum of constancy (C) and contingency (M). Constancy is the uniformity of an event across time intervals, and contingency is the temporal reliability of the event across the time intervals. Predictability in the upstream and downstream sections is $\operatorname{Pr}=0.9$ and $\operatorname{Pr}=1.0$, respectively; therefore, based on available data, the timing of the start of the spawning period, as defined by the presence of fish with $\mathrm{PI} \leq 0.07$, can be considered a highly predictable yearly event, which extended during several weeks in each section (fig. 8). Moreover, the finding of some fish with oocytes in a state of GVBD (indicating resumption of meiosis and imminent ovulation) as well as data obtained through telemetry and collection of larvae, support the conclusion that spawning is occurring during the same periods that we find reproductively ready females (Korschgen, 2007; Papoulias and others, 2007a).
For sturgeon to be physiologically ready to spawn at the same time in the spring every year requires a highly predictive and annually reliable cue to initiate the reproductive cycle months before spawning. If the timing of a reproductive event is certain, then an organism only needs to respond to one or a few reliable cues and can ignore others (Cohen, 1967). We hypothesize that day length (or photoperiod) is the reliable cue that starts the sturgeon reproductive cycle months before the spawning period. Initiation of the cycle can be compared to turning on an internal clock such that the sturgeon begins an extended process of physiologically preparing (indicated by decreasing PI values and changes in hormone levels) to spawn during a specific optimal period in the spring.

Sturgeon in the Missouri River mainstem from St. Louis to Gavins Point Dam are at varying degrees of readiness to spawn within the spawning periods we have identified. This is shown by the temporal and spatial distribution of physiological indicators (PI and hormone levels) for individual fish (fig. 9). This pattern of readiness to spawn is not a consequence of where fish were sampled within each section. Gravid females exhibited a similar readiness to spawn whether they were collected randomly or collected from a fixed location that had been hypothesized to be a suitable spawning location (fig. 10); however, the patterns differ substantially between the upstream and downstream sections. In the upstream section, collected females were increasingly more ready to spawn through the season. In the lower section, readiness to spawn did not show the same trends, perhaps because multiple 'runs' of fish at different stages of readiness were sampled. Because sturgeon are able to migrate hundreds of kilometers, it is possible that in the Boonville section a combination of local and transient fish were sampled that began migrating from different river miles, and thus would be at different reproductive stages. Some of these fish spawn in this section, but a decreasing PI pattern is masked by variation within the sampled population. The patterns observed in the upper section are more similar to those we have observed for groups of fish in the Yellowstone and Wabash Rivers that are physiologically advancing towards spawning in unison. The observed monotonically decreasing trend in PI during the spawning period in the upper section may be related to the presence of the dam. Because the dam acts as a barrier and prevents fish from migrating upstream, individual readiness to spawn may be modified by local environmental factors, and result in synchronizing a previously heterogeneous group. Alternatively, this may be a 'run' of fish cycling together and moving upriver together.

Measures of E2 and KT show promise as physiological indicators sensitive to changes in environmental conditions during the spawning period. The E2:KT ratio continually decreases as the fish becomes increasingly ready to spawn since E2 decreases and KT increases (fig. 11). During the spawning periods, we observed a general negative relation between the ratio of E2:KT and water temperature (fig. 11). The relation is similar, but with more variability, to that observed in the Yellowstone and Wabash Rivers. 

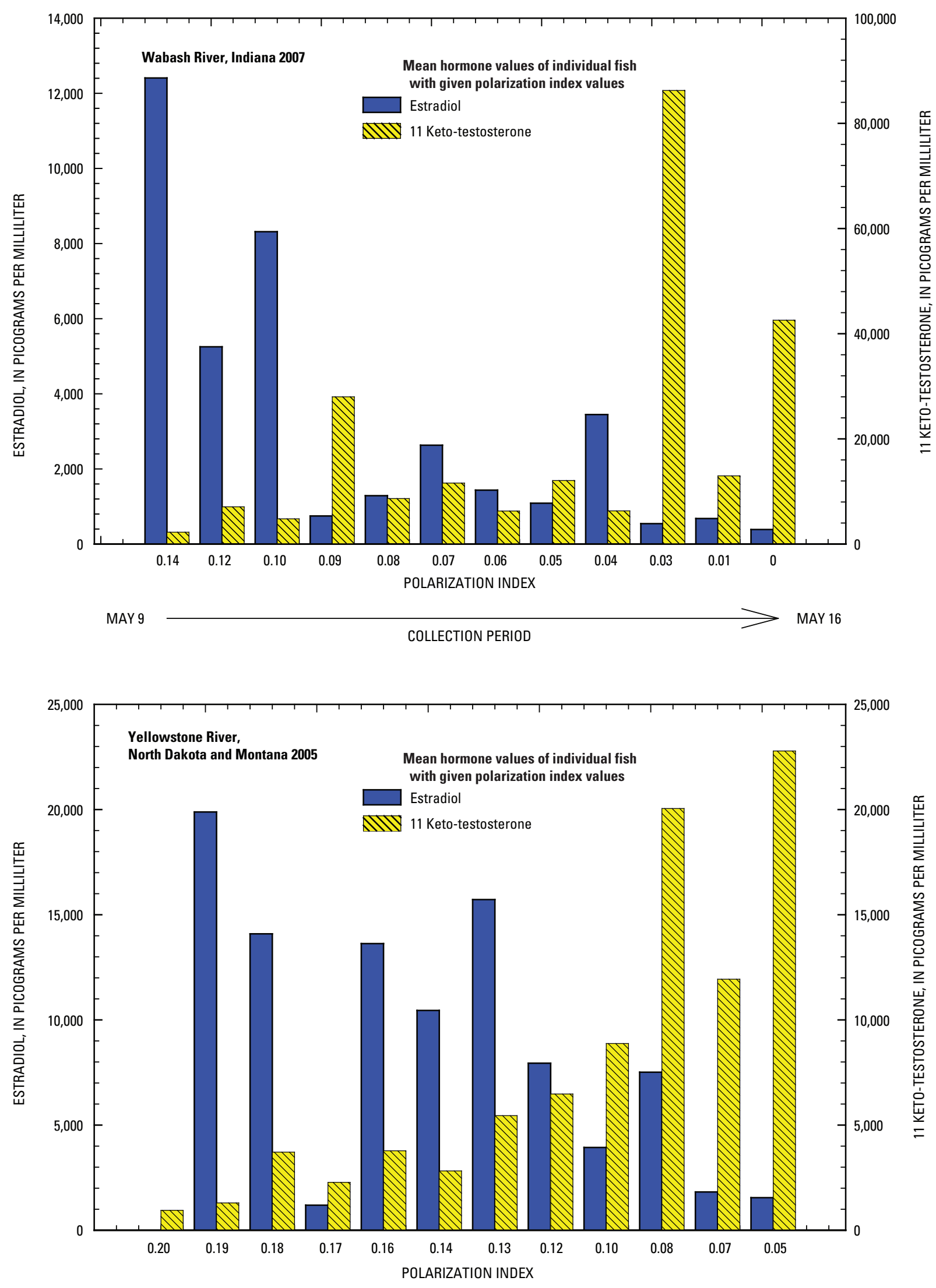

Figure 7. Polarization index (PI) and hormone (17-beta Estradiol and 11 Ketotestosterone) profiles of a population of gravid shovelnose sturgeon that was repeatedly sampled as they migrated up river. 
We evaluated the influence of environmental factors on readiness to spawn with stepwise multiple regression. Discharge, water temperature, and day of year associated with E2:KT measures are highly correlated $(p<0.0001)$, indicating the challenge of separating causal relations. Nevertheless, water temperature was the only significant variable entered into the model and explained 68 percent of the variation in the ratio of $\mathrm{E} 2: \mathrm{KT}$ with time $\left(\mathrm{N}=27, \mathrm{R}^{2}=0.6768, \mathrm{p}<0.0001\right)$.

\section{Gonad Abnormalities and Tumors}

Shovelnose and pallid sturgeon collected from the Missouri River during 2005-08 were observed to have several reproductive abnormalities. The most striking is the severe and frequent incidence of intersex individuals with hermaphroditic gonads. In most cases, a testis with eggs was observed, but occasionally an ovary will have small patches of testicular tissue embedded in it. The gametes can be at any stage of development from immature eggs and sperm to fully ripe (fig. 12). Although we are unable at this time to determine the genetic sex of an individual, we assume that if the gonad mostly is testicular, then it is a genetic male; if it is mostly ovary, then it is a genetic female. The incidence of intersex in male shovelnose sturgeon in the Missouri River is about 12 percent (fig. 13). Studies are underway to determine how intersex develops, what causes intersex, and the severity of the impact of intersex on reproductive behavior and viability. Many species of sturgeon have been reported to show intersex, but observations are rare, and most reports come from greatly disturbed river systems in Russia (Papoulias and others, 2007b). Experimental research with other species of fish, amphibians, and reptiles has demonstrated that exposure to various stressors such as radiation, food deprivation, changes in temperature, hybridization, and natural and synthetic hormones, as well as a diversity of chemicals that interfere with the endocrine system, can result in the development of intersex (Teh and others, 2000; Park and Kidd, 2005; Fujioka, 2006). Endocrine-disrupting chemicals are present in water, sediment, and biota in the Missouri River, but no studies have linked their presence to intersex in sturgeon (Petty and others, 1995; Echols and others, 2008; C.E. Orazio, U.S. Geological Survey, written commun., 2009)

Other abnormalities, in addition to intersex, also have been observed. Occasionally, individuals were determined to have both a testicular lobe and an ovarian lobe, or missing a lobe altogether (fig. 14). In many sturgeon, the shape or size of each lobe of the pair of the gonad lobes differs greatly. Microscopically, we have observed individual oocytes within an ovary to be dividing as if the oocyte had been fertilized. Commonly, we find scattered, swollen, fluid-filled oocytes in mature ovaries and many atretic oocytes remaining in spent ovaries. Lastly, we have found three teratomas in shovelnose sturgeon, and one in a pallid sturgeon (fig. 15). Teratomas are rare tumors derived from germ cells and usually contain several types of tissues. Causes for teratomas and the other gonadal abnormalities in the sturgeon are not known, nor have these disorders been evaluated for their effects on sturgeon reproduction.

\section{Movement and Behavior}

Telemetry studies were conducted with 100 gravid female shovelnose sturgeon in 2005 and 100 again in 2006. Fifty females were captured and implanted with transmitters in early spring before spawning in the upstream and downstream sections. The goal was to determine the direction, timing, and magnitude of sturgeon spawning migrations, and to determine if shovelnose sturgeon were spawning and where. Several pallid sturgeon were implanted opportunistically in 2005 and 2006, but none were in reproductive condition. Tracking data indicated that reproductive female shovelnose sturgeon implanted with transmitters and DSTs between February and April generally move upstream to spawn (DeLonay and others, 2007b) (fig. 16). In 2005, upstream spawning migrations of shovelnose sturgeon averaged $74.7 \mathrm{~km}$, with 50 percent moving more than $62.8 \mathrm{~km}$. In the lower study section, the average upstream migration distance was $176.1 \mathrm{~km}$ with 50 percent of upstream migrants moving more than $190.9 \mathrm{~km}$ (fig. 17). Results in 2006 were similar (DeLonay and others, 2007b). Female sturgeon implanted in the lower section moved earlier, farther, and faster than those implanted in the upper section. Subsequent recapture of female shovelnose sturgeon indicated that females moving upstream more than $16 \mathrm{~km}$ attempted to spawn or spawned completely, whereas females that did not move upstream or moved downstream did not spawn. Recapture attempts in 2005 and 2006 indicated that 85 percent $(n=20,2005)$ and 78 percent $(n=23,2006)$ of recaptured tagged female shovelnose sturgeon spawned completely (DeLonay and others, 2007b).

Tracking location data and data from patterns of depthuse recorded by DST tags indicated that female shovelnose sturgeon migratory behavior generally can be characterized by a single, often rapid upstream movement to the spawning site, followed by a variable downstream return movement (fig. 18). As in other sturgeon species, spawning is hypothesized to occur at the most upstream location, or apex, of the spawning migration. Depth-use data recorded by DST tags implanted in migrating female shovelnose sturgeon indicate a characteristic pattern (fig. 16). During the pre-spawn phase, stationary fish typically show low variability in depth use. At the onset of rapid upstream migration, the variability in depth use increases dramatically. Some of the variation in depth use results from changing water depth as the fish migrates longitudinally through bends and crossovers; an unknown part of depth-use variation may be attributable to local, lateral movements that would sample a range of depths. This pattern significantly changes to one of low variability when the fish slows or stops near the apex of its migratory route, indicating that the fish has changed state and is initiating spawning (DeLonay and others, 2007a; DeLonay and others, 2007b; Holan and others, 2009). Variation in depth use is low during the post-spawn 

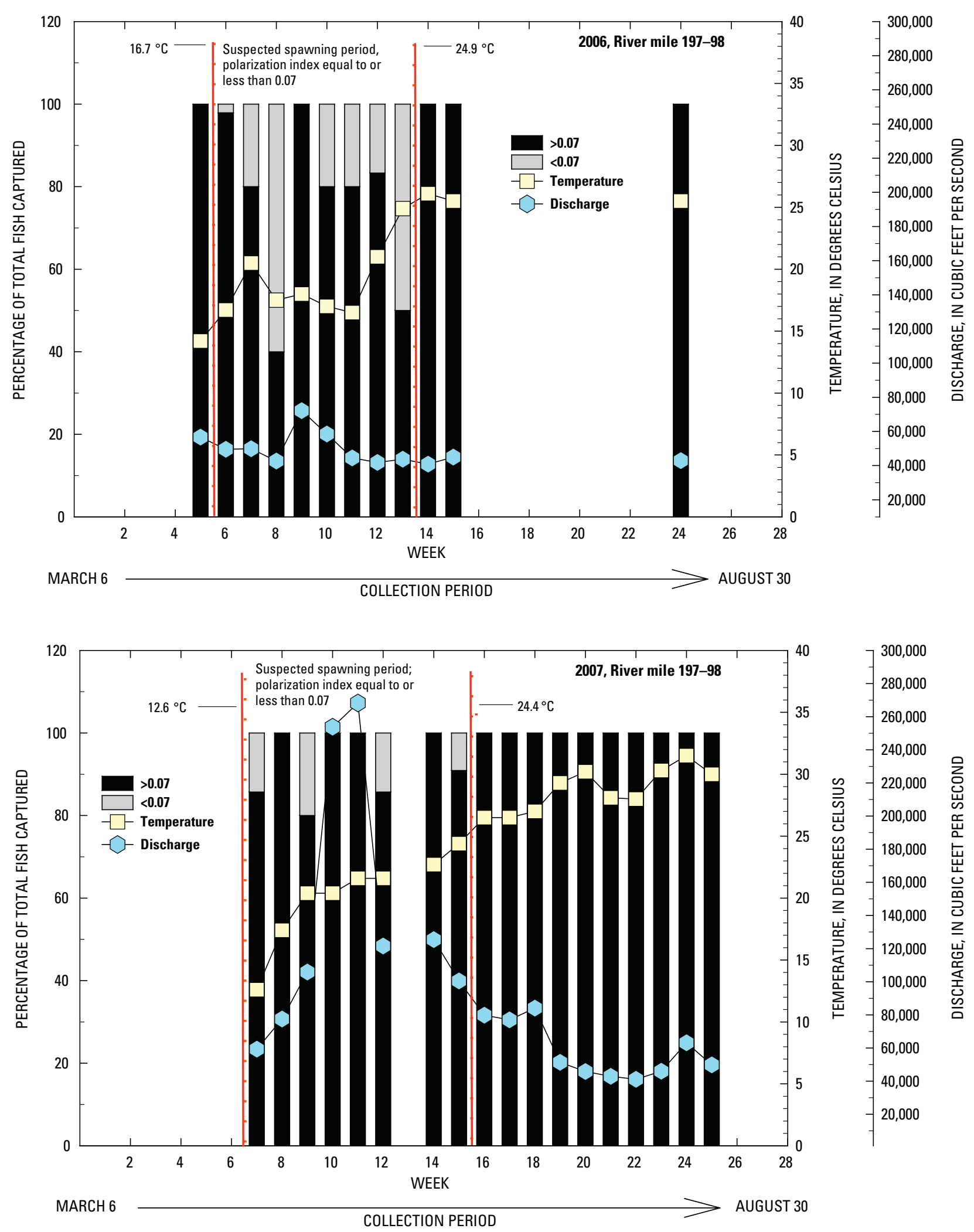

Figure 8. The relation between spawning readiness, water temperature, and discharge. Stacked bars are the percentage of gravid shovelnose sturgeon collected from the Missouri River with polarization index (PI) less than or equal to 0.07 and Pls greater than 0.07 . 

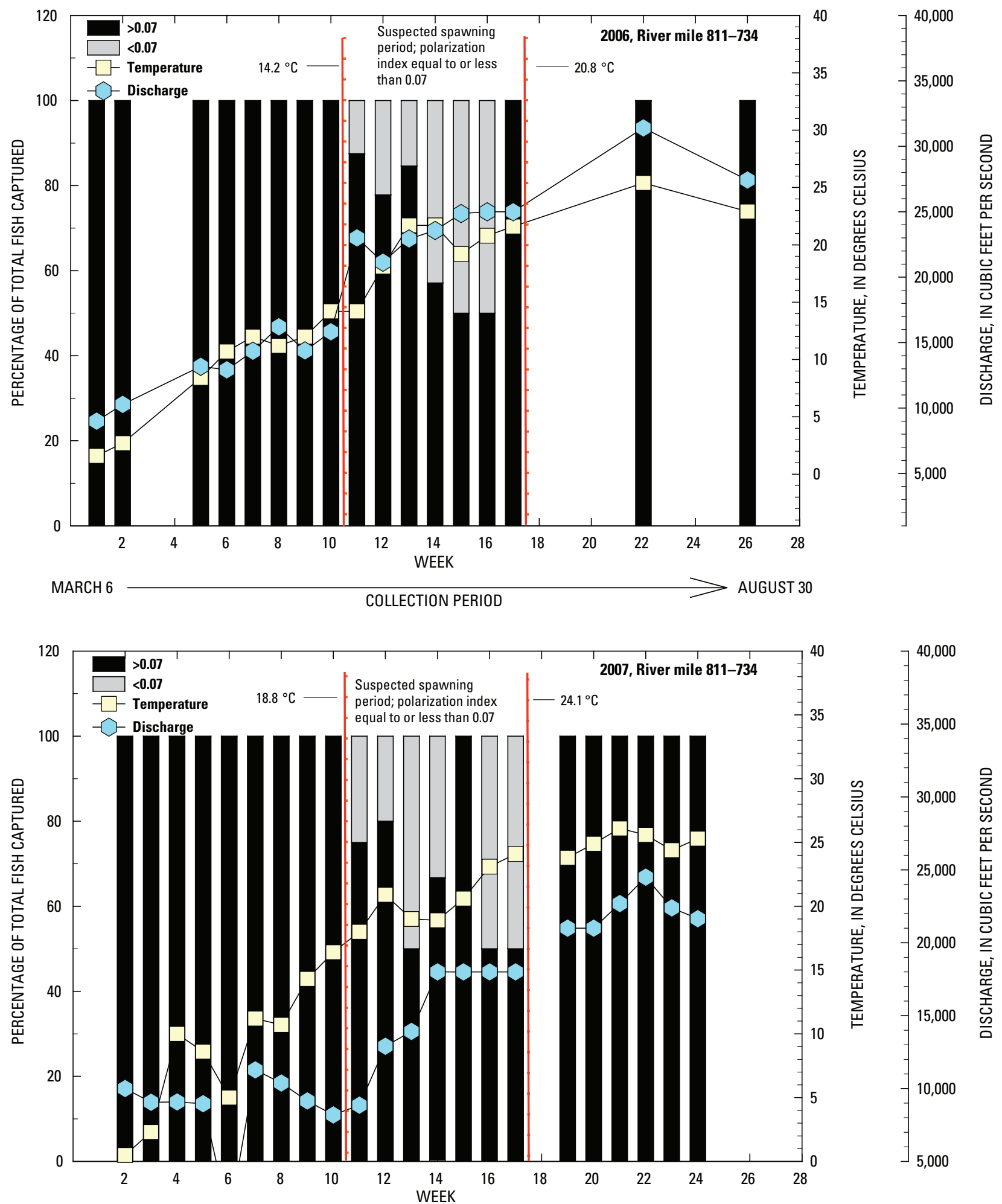

MARCH 6

COLLECTION PERIOD

Figure 8. The relation between spawning readiness, water temperature, and discharge. Stacked bars are the percentage of gravid shovelnose sturgeon collected from the Missouri River with polarization index (PI) less than or equal to 0.07 and PIs greater than 0.07.-Continued 

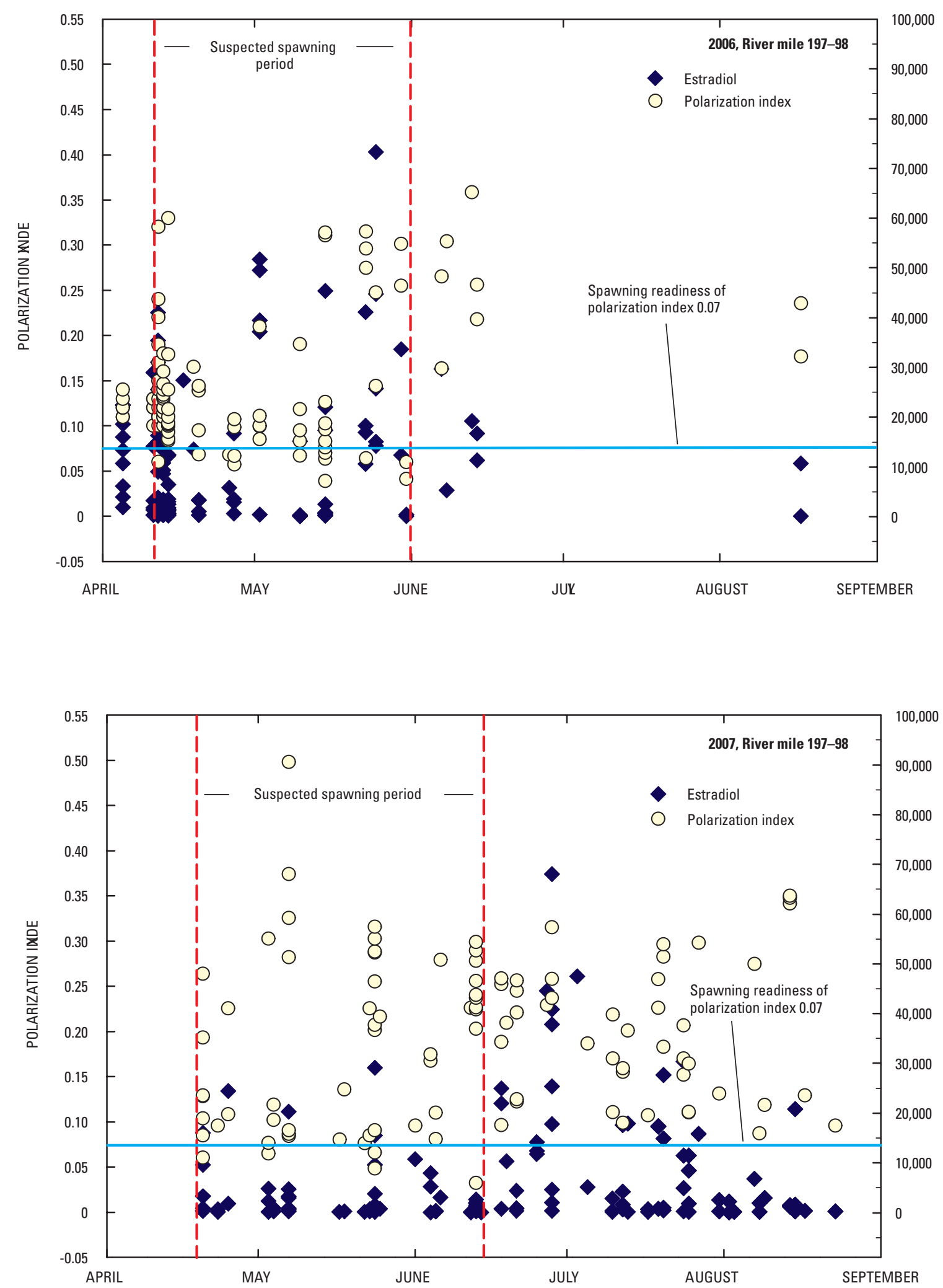

Figure 9. Temporal and spatial distributions of individual gravid shovelnose sturgeon at different stages of readiness to spawn, as indicated by polarization index and estradiol values, spring to fall. 

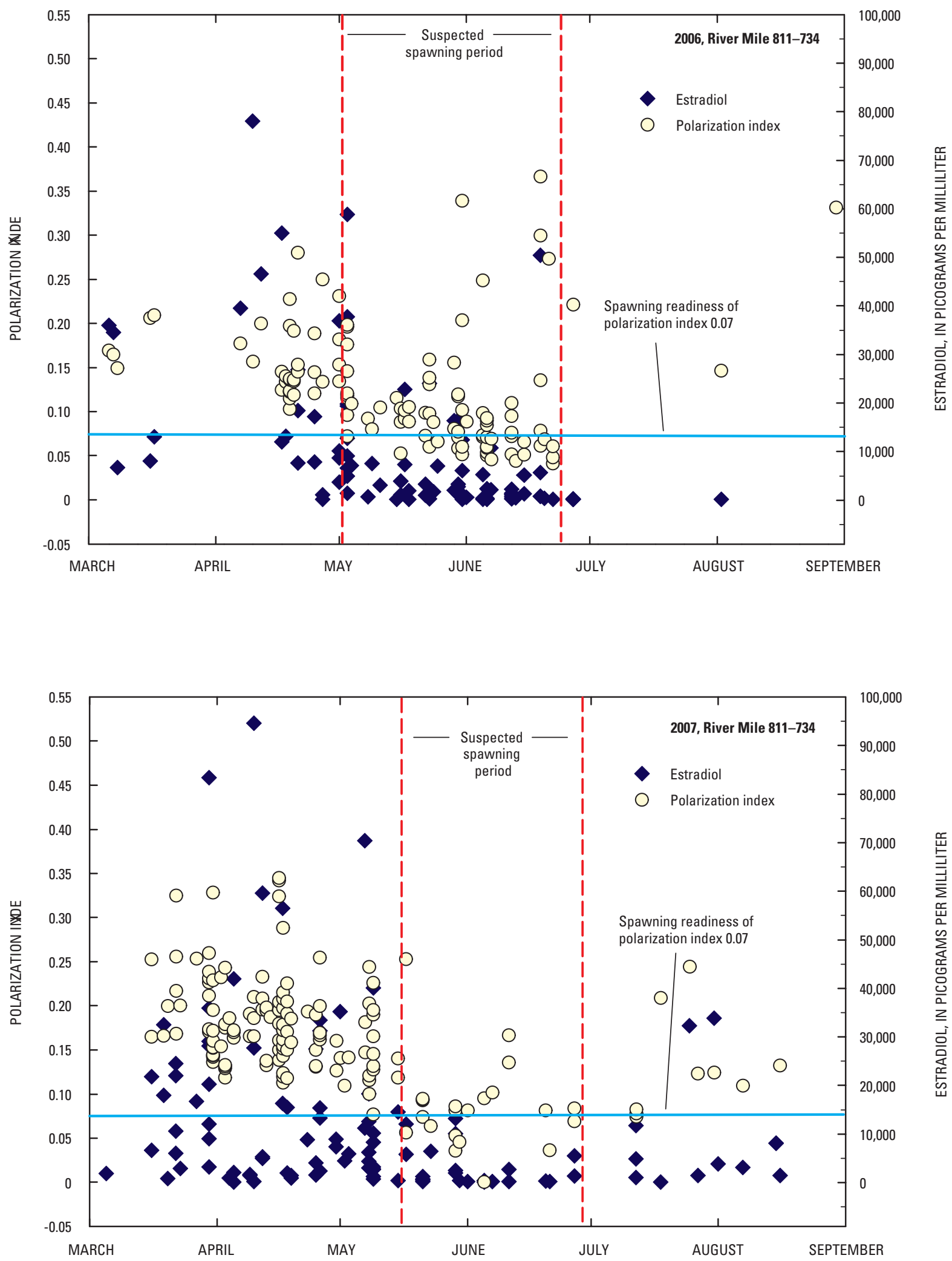

Figure 9. Temporal and spatial distributions of individual gravid shovelnose sturgeon at different stages of readiness to spawn, as indicated by polarization index and estradiol values, spring to fall.-Continued 

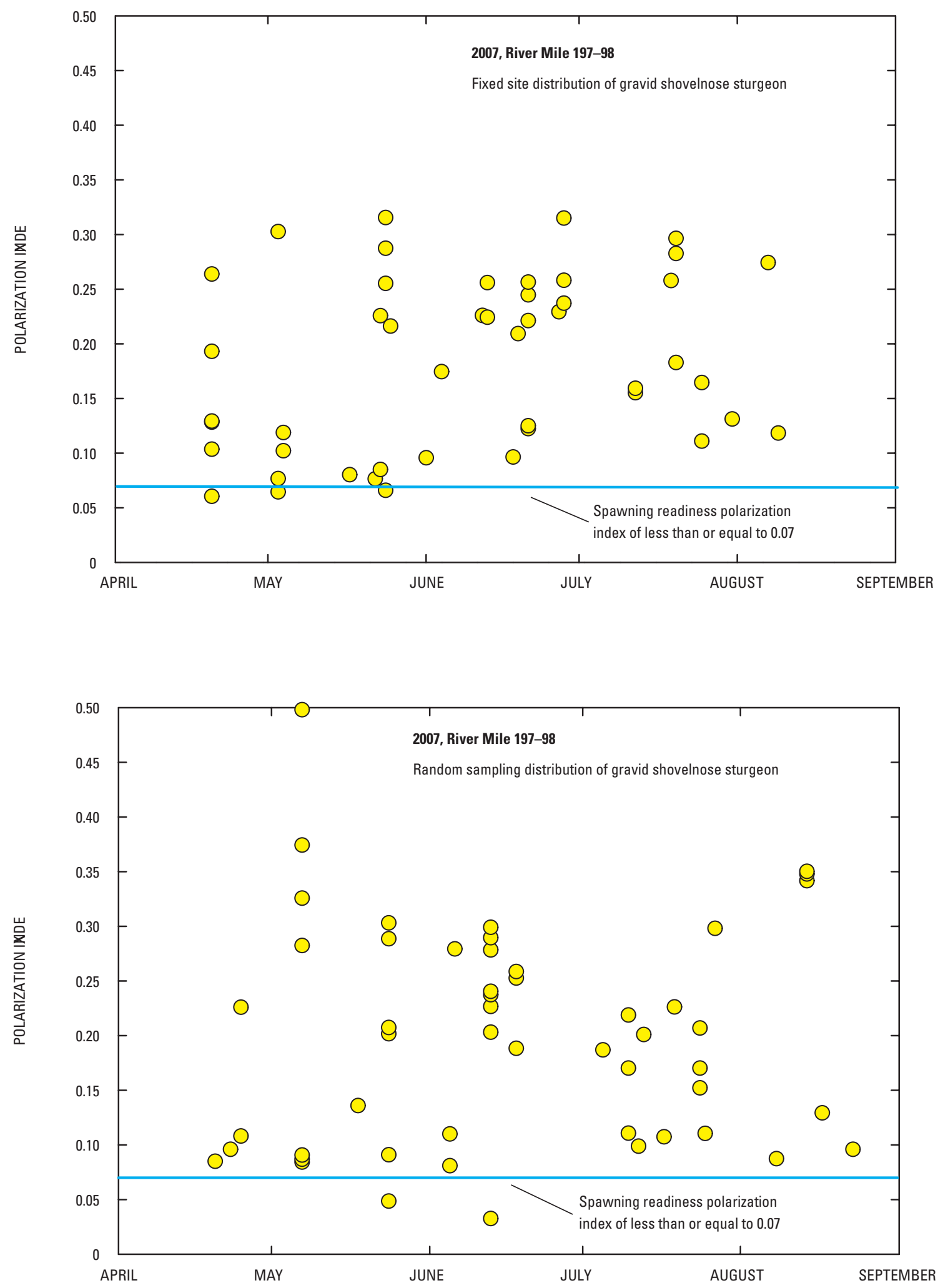

Figure 10. Temporal trend in individual polarization indices of gravid Missouri River shovelnose sturgeon sampled from random and fixed sites within river miles 196.6-97.6 and 811-734. 

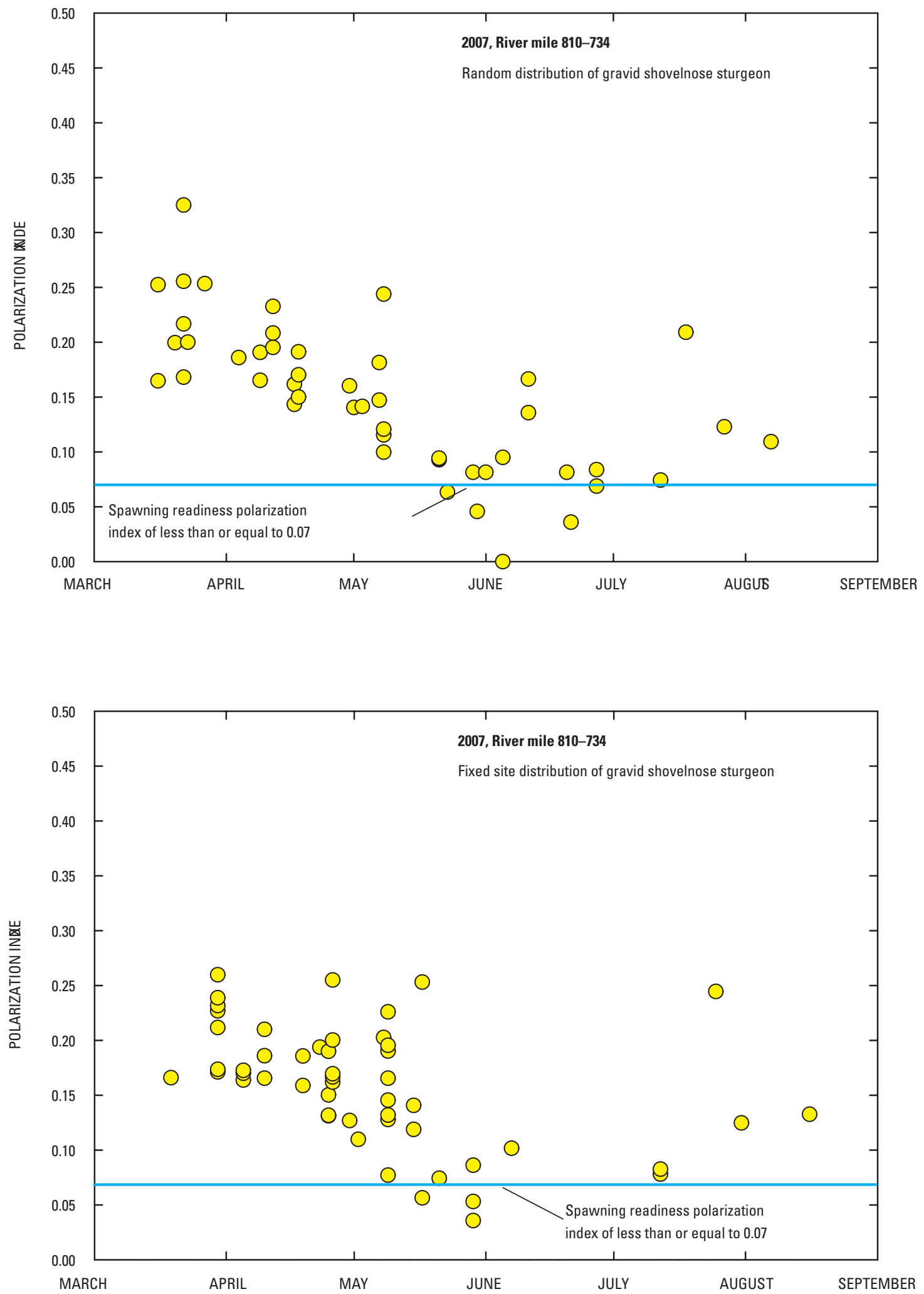

Figure 10. Temporal trend in individual polarization indices of gravid Missouri River shovelnose sturgeon sampled from random and fixed sites within river miles 196.6-97.6 and 811-734.-Continued 

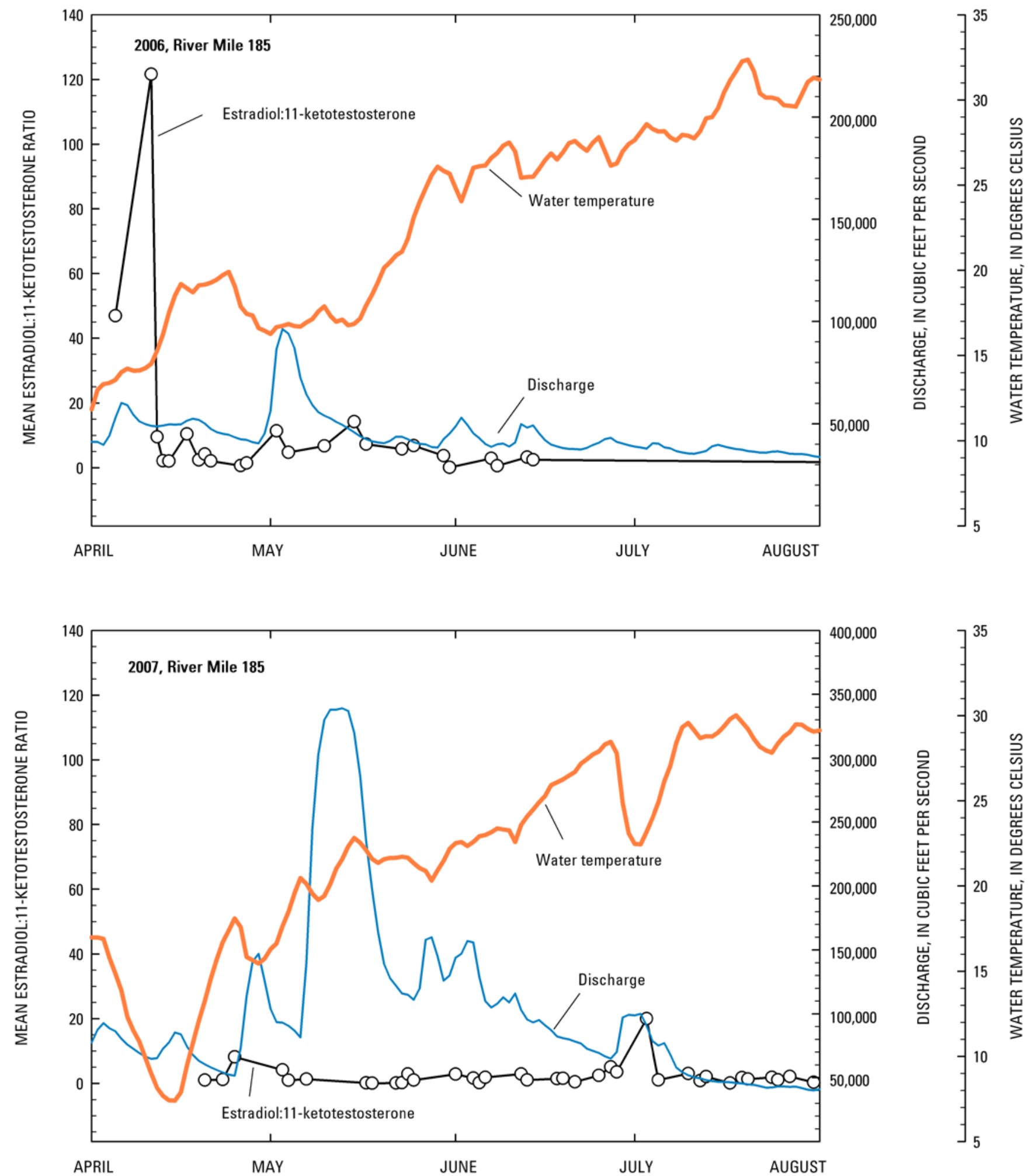

Figure 11. Change in E2:KT (estradiol: 11-ketotestosterone) ratio in gravid shovelnose sturgeon from the Missouri River during two years at two locations relative to prevailing flow and temperature conditions. The E2:KT ratio is a diagnostic indicator of readiness to spawn. Estradiol increases very early in spring then decreases as the spawning cycle progresses; 11-ketotestosterone increases later in the cycle, then decreases in close proximity to ovulation. 

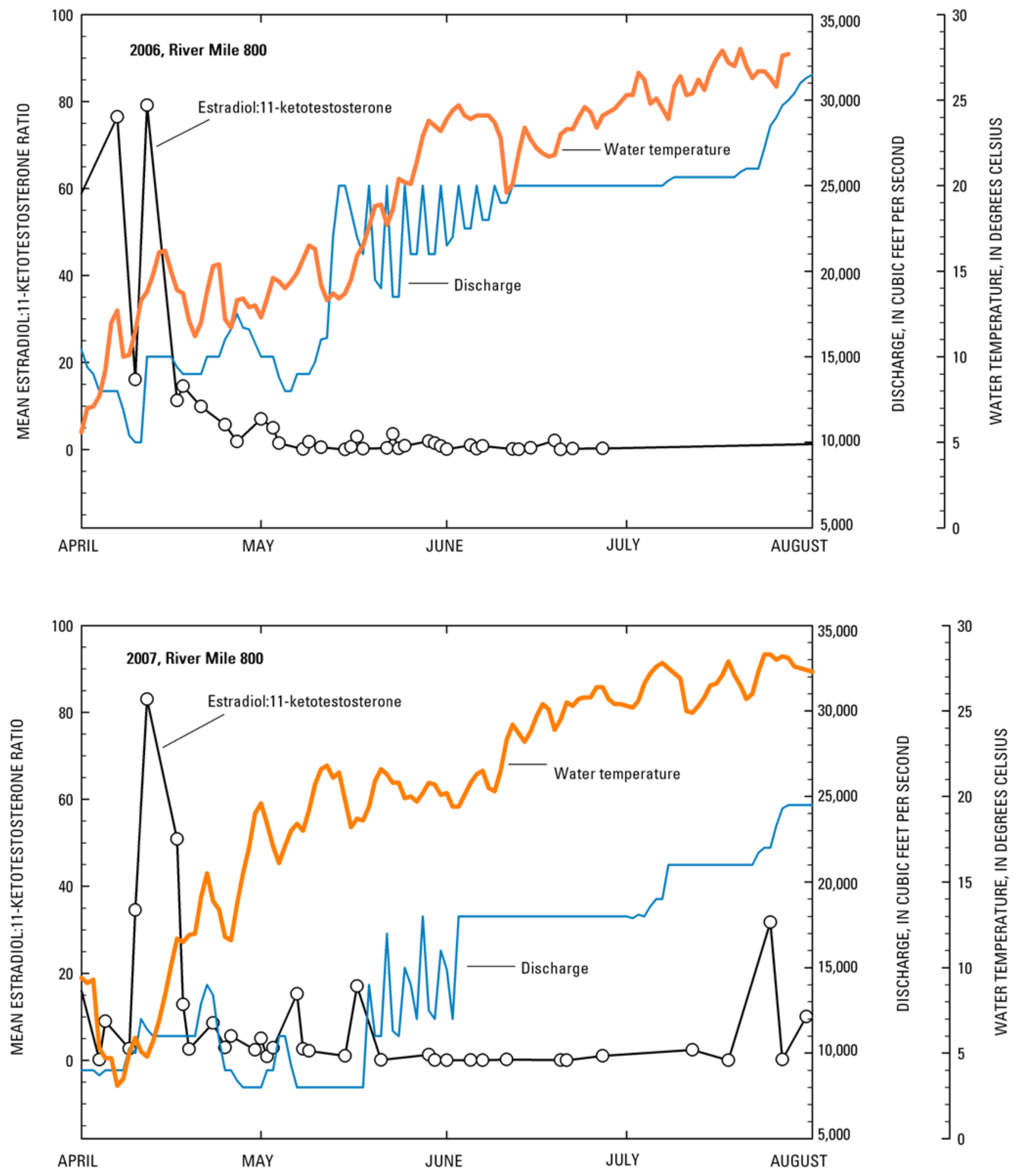

Figure 11. Change in E2:KT (estradiol: 11-ketotestosterone) ratio in gravid shovelnose sturgeon from the Missouri River during two years at two locations relative to prevailing flow and temperature conditions. The E2:KT ratio is a diagnostic indicator of readiness to spawn. Estradiol increases very early in spring then decreases as the spawning cycle progresses; 11-ketotestosterone increases later in the cycle, then decreases in close proximity to ovulation.-Continued 

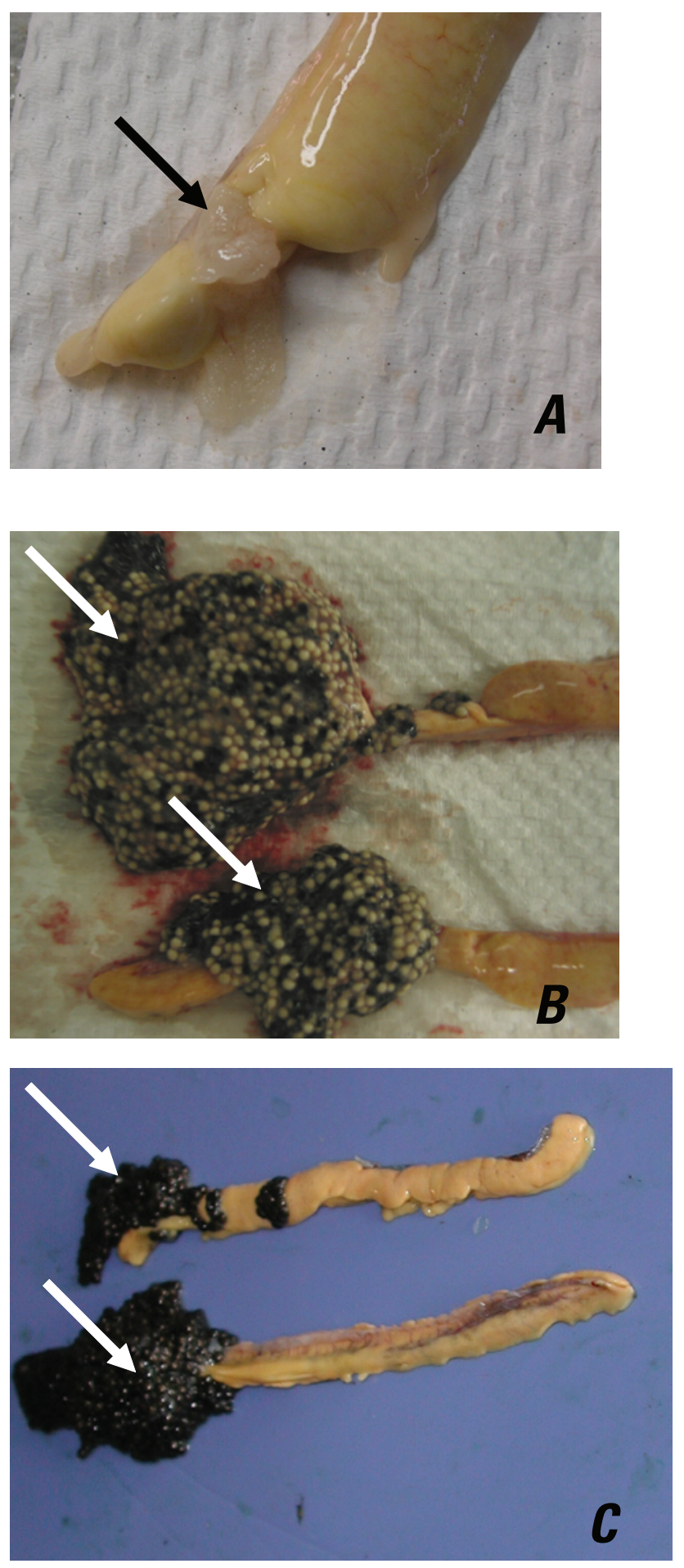

Figure 12. Examples of gonadal intersex found in sturgeon from the Missouri River. (A) Arrow denotes small clear early-stage oocytes on immature testis. (B) Arrows denote early vitellogenic oocytes on maturing testes. (C) Arrows denote mature oocytes on mature testes. phase, while the fish is at its presumed spawning location, then increases episodically coincident with downstream movements (fig. 16). Location and movement data collected in 2005 and 2006 indicate that shovelnose sturgeon may move considerable distances during spring spawning migrations, and that spawning is occurring at multiple locations (fig. 18).

The objective of the extensive shovelnose sturgeon study conducted in 2007 was to describe reproductive migratory patterns of male and female shovelnose sturgeon, locate aggregations of spawning adult sturgeon, and characterize discrete spawning locations in the 216 river miles immediately downstream from Gavins Point Dam, Nebraska. A companion intensive telemetry study also was conducted with a small number of pallid sturgeon in reproductive condition in the same area with similar objectives. The overall goal of the research was to provide data necessary to construct a model of shovelnose sturgeon spawning to compare against the limited information acquired using the pallid sturgeon during a year when no spring flow pulses were released from the dam.

In February through April, 2007, 176 shovelnose sturgeon were implanted with transmitters and DST tags. Of these, 98 were gravid female shovelnose sturgeon, 21 were reproductive males (ripe), and 57 were nonreproductive adults of either sex. In addition 5 reproductive pallid sturgeon (2 females and 3 males) were captured and tagged using selective, targeted sampling protocols developed from telemetry data on pallid sturgeon collected in 2005 and 2006. Tracking crews surveyed more than $20,900 \mathrm{~km}$ of river and located tagged sturgeon 4,771 times during the prespawn migration, spawning, and post-spawn period. Tracking crews also selectively targeted shovelnose sturgeon for recapture during their upstream migration, and immediately upon reaching the apex of their migratory route. This was an attempt to provide a measure of verification to support the hypothesis that female sturgeon are spawning at their migratory apex. Of the 176 tagged shovelnose sturgeon, 109 were recaptured (62 percent), their reproductive condition assessed, and the DST records retrieved. Both gravid female pallid sturgeon also were recaptured following spawning.

In 2007, female shovelnose sturgeon generally followed the characteristic pattern observed in previous years- $\mathrm{a}$ single upstream movement to the probable spawning location (fig. 18). Female sturgeon reached the apex of the migratory movement from late April to mid June. Downstream movement of post-spawn shovelnose sturgeon females was somewhat more variable. Some female sturgeon, later confirmed to have spawned, lingered nearly motionless at the apex of their spawning migration (presumed spawning site) for days to weeks before moving downstream, whereas others turned and rapidly moved downstream (fig. 18). Reproductive males, however, appeared to be extremely variable among individuals, indicating that males may be capable of employing more than one reproductive strategy (fig. 19). Some males behaved similarly to females, moving rapidly upstream to a single migratory apex. Other males exhibited a migratory pattern with several upstream apices that presumably corresponded 


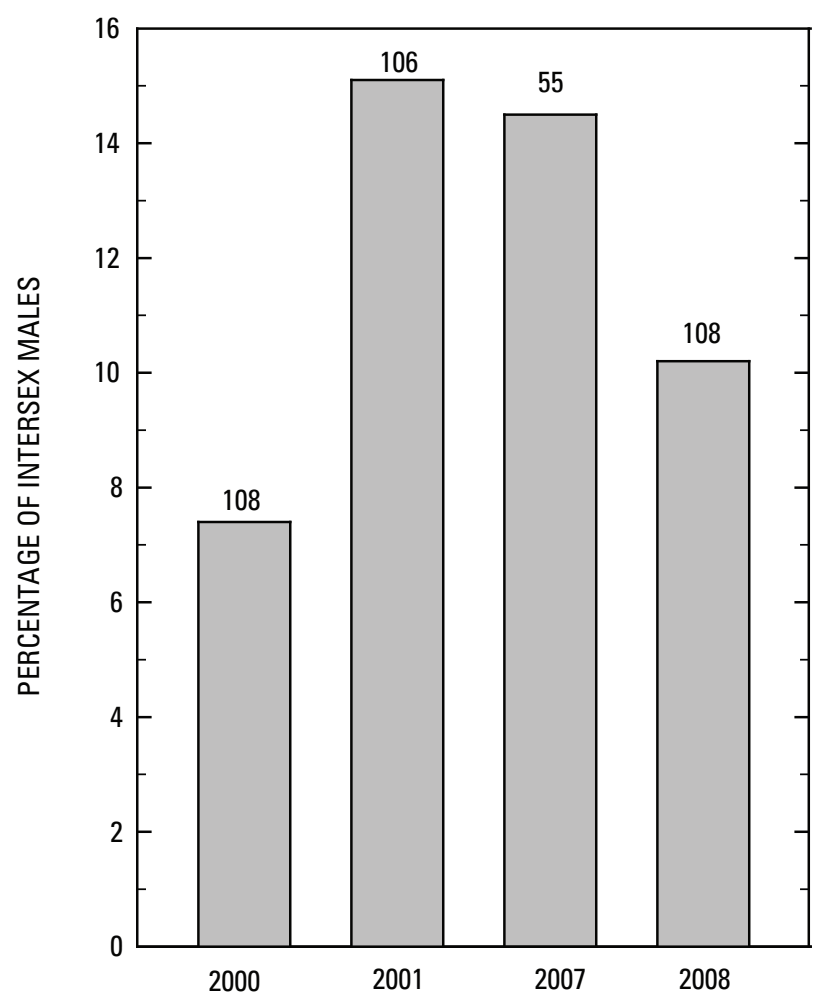

Figure 13. Incidence of sturgeon with intersex gonads among total male sturgeon caught in the Missouri River between Gavins Point Dam and St. Louis, 2000-08. Numbers above the bars denote the total number of males evaluated.

to multiple spawning sites and opportunities. Still other males did not show a strong upstream movement, and instead moved up and downstream along several river bends, perhaps surveying multiple spawning locations within a river reach for ready females. Nonreproductive adults generally moved less and their movement patterns were extremely variable. Despite increased numbers of tagged fish in a smaller geographic area compared to 2005-06, few aggregations, or simultaneous locations of reproductive male and female sturgeon, were observed. Based upon location, movement, and recapture information, it is clear that shovelnose sturgeon are spawning over an extended period of time at many locations along the mainstem of the Lower Missouri River (figs. 6 and 20).

Targeted captures of selected shovelnose sturgeon in 2007 appeared to support the hypothesis that females are spawning at the apex of their migration. Females captured moving upstream in the mainstem Missouri River before reaching their apex had not yet spawned. Females captured while moving downstream in the mainstem Missouri River either had already spawned or never did; however, in 2007, flows from the major tributaries were unusually high, and an unexpected number of shovelnose sturgeon in all reproductive states utilized tributaries, most significantly the Big Sioux River. Of the 176 shovelnose sturgeon implanted in 2007 , 65 (44 females and 21 males) were located at least once in the Big Sioux River. Of the females present in the Big Sioux River, 26 were gravid when implanted, and 12 of the males were ripe. Distances moved in the Big Sioux River were not related to reproductive state. The 44 females traveled upstream a mean distance of $36.8 \mathrm{~km}$. The 21 male shovelnose sturgeon traveled a mean distance of $52.9 \mathrm{~km}$ up the Big Sioux River.

Patterns of tributary use were variable among shovelnose sturgeon. Some sturgeon moved upstream in the mainstem Missouri River to spawn following the expected characteristic pattern then descended rapidly (presumably after spawning) only to enter and move up the Big Sioux River. Others moved rapidly up the Missouri River mainstem

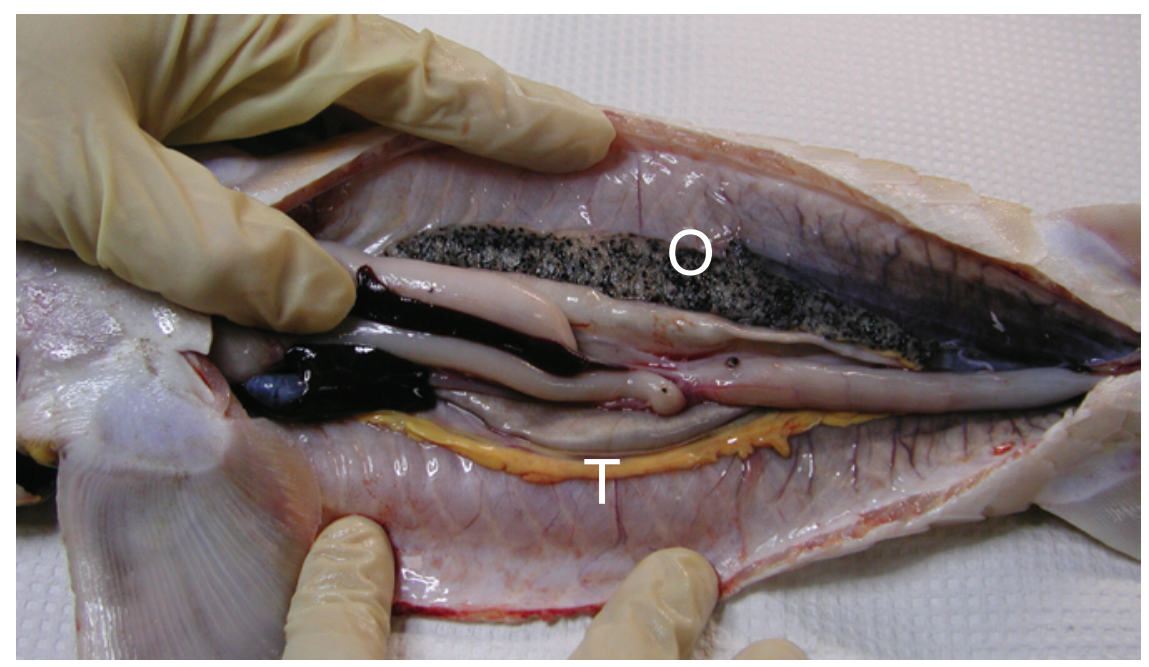

Figure 14. Shovelnose sturgeon captured in the Missouri River with both an ovarian lobe $(0)$ and a testicular lobe (T). and entered the Big Sioux River to spawn. Still others moved up the Missouri River into the Big Sioux River, then subsequently moved out of the Big Sioux River, and continued upstream in the Missouri River mainstem to spawn at some distant location. Spawning was verified for all three patterns through selective recapture of tagged individuals. The relative importance of tributaries to sturgeon reproduction in the Lower Missouri River is largely unknown. We know from capture efforts that sturgeon continue to feed for at least a part of their upstream migration. The observed use of tributaries in 2007 may indicate either the opportunistic use of available food resources afforded by tributaries, the flexibility of the shovelnose sturgeon to utilize smaller tributaries for 

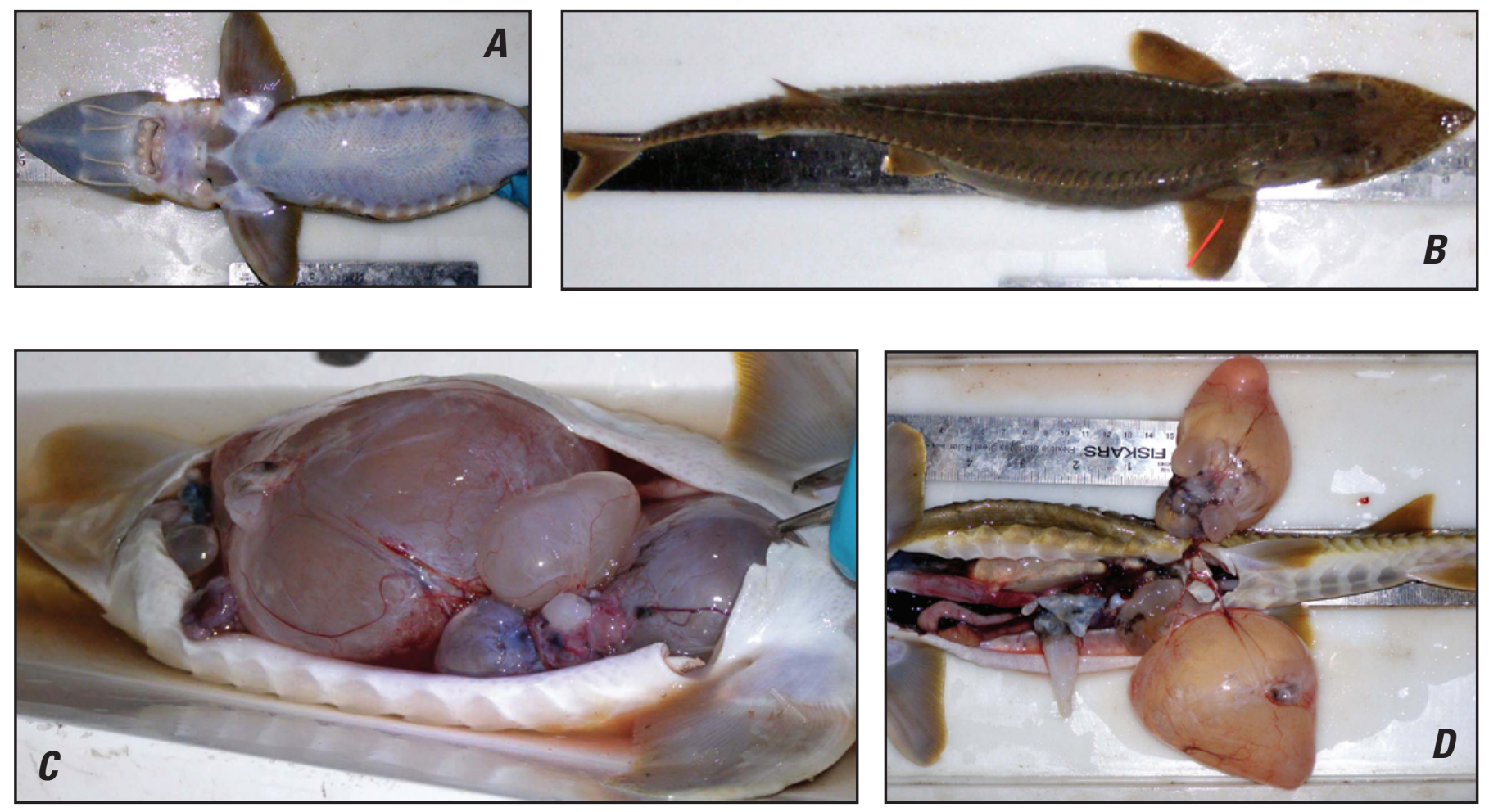

Figure 15. Shovelnose sturgeon from the Missouri River with rare teratoma tumors. Of hundreds of sturgeon collected during 2005-08, four individuals with teratomas were identified. (A) Ventral view. (B) Dorsal view. (C) and (D) Teratomas in body cavities.

spawning, or perhaps both. An inherent flexibility may explain in part why shovelnose sturgeon remain relatively common, whereas pallid sturgeon are endangered.

An increased number of shovelnose sturgeon entered the Missouri National Recreational River (MNRR) segment to spawn in 2007, compared to earlier years. Part of the increase is attributable to the larger numbers of shovelnose sturgeon implanted in the upstream section, and their close proximity to Gavins Point Dam. For the most part, female spawning movements were consistent with the expected pattern in this reach; however, initial examination of the data indicates that movement by some female shovelnose sturgeon females near the dam may show a plateau pattern rather than a prominent apex followed by downstream movement. Recapture of several fish that appeared to plateau during their upstream migration indicated that the fish had not yet spawned or waited for an extended period at this location to spawn. Among female shovelnose sturgeon that did not spawn, two patterns were prevalent. First, tagged sturgeon that never migrated upstream or migrated upstream extremely slowly (approximately 28 percent of reproductive females) generally did not spawn successfully. Second, fish that migrated upstream rapidly, but lingered for extended periods, appeared to be less likely to spawn. An in-depth analysis of these patterns is ongoing, but it is likely that disrupted migration patterns indicate that a fish has reached a suitable spawning location or a critical physiologi- cal period, but conditions (environmental or lack of suitable mates) are not favorable for spawning.

Intensively tracked gravid female pallid sturgeon exhibited movement patterns similar to the characteristic migrations made by female shovelnose sturgeon. The two female pallid sturgeon tagged in 2007 were inferred to be of wild origin based on their size, lack of hatchery marks, and genetic tests for hatchery parentage. Both of these fish showed intervals of rapid upstream movement, followed by intervals of variable, slower downstream movement (figs. 21 and 22). They were recaptured after the initiation of downstream movement during the post-spawn phase. Upon examination of the ovaries, both were determined to have spawned completely. The first female was captured on March 29, 2007, at river mile 650.3 with an egg polarization index of 0.12 , and moved nearly 80 $\mathrm{km}$ upstream from the implantation location before spawning in the channelized reach downstream from Sioux City, Iowa (river mile 734), probably in late April to early May (figs. 6 and 21). The second female, captured on March 26, 2007, at river mile 659.7 , with an egg polarization index of 0.17 , moved $179.6 \mathrm{~km}$ upstream before spawning upstream from Ponca State Park within the MNRR reach, probably in mid May (figs. 6 and 22). It was recaptured after moving downstream to river mile 756.5 on May 23, 2007. This was the first direct evidence that pallid sturgeon spawn in the MNRR reach and in the channelized river upstream from the Platte River. The DST data, in combination with telemetry relocations, are 

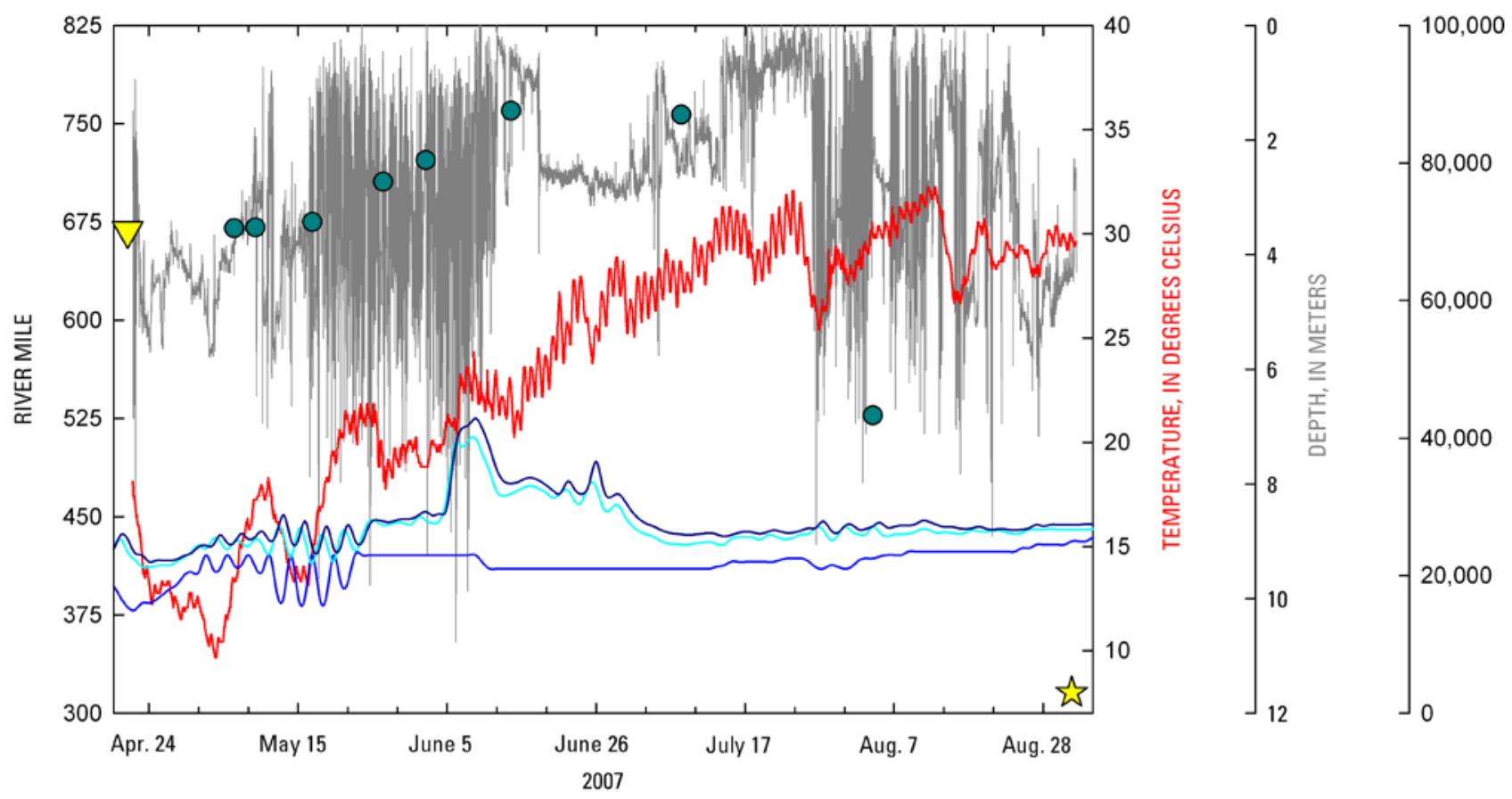

\section{EXPLANATION}

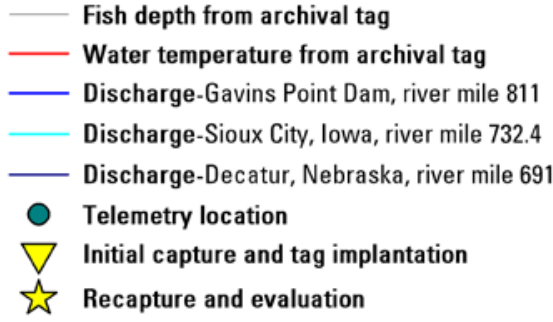

Figure 16. Depth and temperature recorded from data storage tag, discharge from the nearest upstream gages, and telemetry locations for implanted reproductive female shovelnose sturgeon, SNS05-066. Fish was implanted in reproductive condition and later recaptured and determined to have spawned.

the first complete records of adult pallid sturgeon migration and spawning in the Lower Missouri River.

Data from tagged male pallid sturgeon in reproductive condition are similar to data from male shovelnose sturgeon. Limited data indicate that spawning male pallid sturgeon may exhibit sporadic upstream migrations with multiple apices, indicating multiple spawning events at multiple locations. At no time were telemetry-tagged pallid sturgeon males and females found in close proximity to one another in 2007. No aggregations of tagged reproductive pallid sturgeon were observed, although small numbers of tagged individuals limit conclusions. The migration apex data indicate that, like shovelnose sturgeon, pallid sturgeon within these study segments are spawning at multiple locations during a variety of conditions (fig. 23).

Studies in 2008 expanded the intensive telemetry study to include the lower and upper study sections. Large adult pallid sturgeon (greater than $2.0 \mathrm{~kg}$ ) were selectively targeted for capture using large mesh gillnets $(8.9 \mathrm{~cm}$ bar mesh $)$ and trotlines baited with earthworms in the Lower Missouri River from the Platte River, Nebraska, upstream to the Big Sioux River, Iowa (upstream study section), and from the Osage River, Missouri, upstream to the Grand River, Missouri (downstream study section). Of the 218 pallid sturgeon captured, 190 were hatchery-origin fish, and 28 were wild fish (fig. 24). Length and weight data, and assessment of the reproductive status of captured fish using minimally-invasive methods, indicate that some limited reproduction and recruitment are occurring in the Lower Missouri River. Immature, non-reproductive, wild pallid sturgeon are present in small numbers. Data also indicate that hatchery-propagated fish appear to grow at a rate comparable to wild fish, are reaching reproductive maturity, and are ready to spawn in the Lower Missouri River.

Crews attempted to implant two gravid females and three ripe males in each study section in 2008. In the downstream 


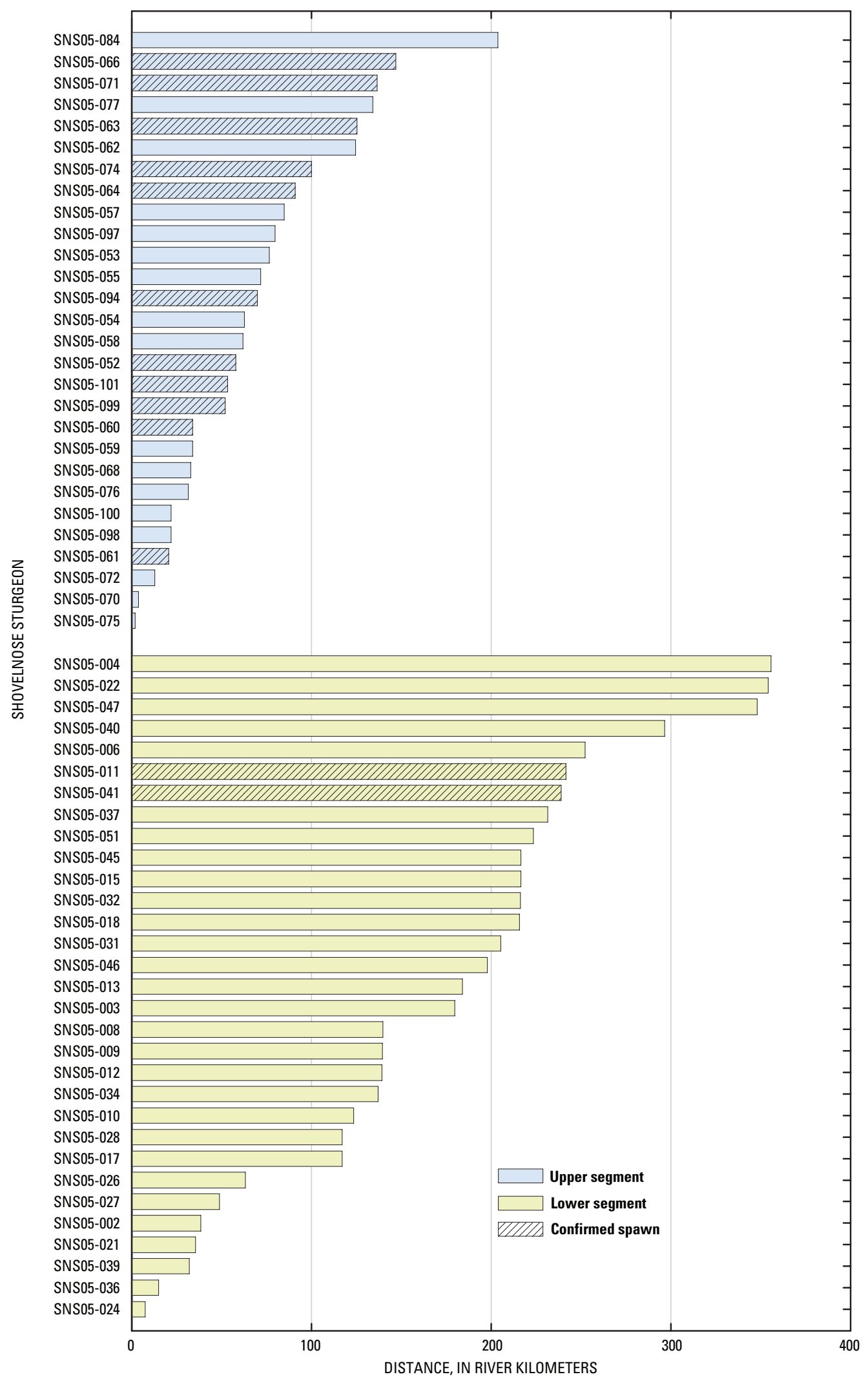

Figure 17. Displacement of shovelnose sturgeon making an upstream migration in 2005 calculated by subtracting the capture and implantation location from the maximum upstream location. Data are separated by study segment. Hatched bars indicate sturgeon that were recaptured and determined to have spawned or attempted to spawn. 
study section, four gravid females actually were captured and implanted with transmitters and DSTs; no ripe males were collected. The four females were captured and implanted on March 25, 2007, March 31, 2008, April 4, 2008, and April 23, 2008. All four females previously had been marked with coded wire tags, indicating they were progeny of the hatchery propagation program spawned in 1992 or 1997. In the upstream study section, one gravid female and three ripe males were implanted with telemetry devices. The female was captured and implanted on April 11, 2008 and the males were implanted on April 10, 2008, April 16, 2008, and April 24,2008 . We also attempted to recollect, reevaluate, and retag pallid sturgeon implanted in previous seasons. Seven telemetry-tagged pallid sturgeon were successfully recaptured, their archival tags replaced, and new transmitters implanted; none were determined to be in reproductive condition. Twenty additional untagged adult pallid sturgeon greater than $2 \mathrm{~kg}$ (not in reproductive condition) also were implanted during winter and spring collections.

Three of the four reproductive female pallid sturgeon in the downstream section swam from 85 to 185 river miles upstream before stopping at their presumed spawning locations (figs. 25-27). Based upon movement patterns and behavioral observations, spawning was presumed to have occurred near Glasgow, Missouri, at river mile 230.1 (figs. 6 and 25), downstream from the Kansas River at river mile 366.4 (figs. 6 and 26), and just upstream from the Kansas River at river mile 369.5 (figs. 6 and 27). The fourth female was suspected to have shed her transmitter, as the transmitter was stationary. All three of the females that moved upstream were recovered and were determined to have spawned by surgical examination of the gonads. All three females stopped at the uppermost point of their migratory movement (apex) and began a repeated series of movements up and down along a $0.5-0.8-\mathrm{km}$ length of revetted outside bend. We believe these movements are characteristic of spawning behavior. Repeated bouts of movement ceased after 12-36 hours. Each fish then remained stationary at the lowest point of the probable spawning reach for several days to weeks, followed by moving downstream at a variable rate. The archival tags matched the pattern characteristic of migrating shovelnose sturgeon that also had completely spawned in 2005-07 (figs. 25-27). All three pallid sturgeon appear to have spawned in the downstream study section during the first 10 days in May at water temperatures between 16 and $18{ }^{\circ} \mathrm{C}$. Downstream movement of post-spawn females was extremely variable, but by late fall all three had moved downstream into the Mississippi River.

The tagged gravid female in the upstream study section was recaptured in early June after intensive tracking through the spawning season. She was determined to have completely spawned based on direct observations of the gonads. The DST was retrieved, and the transmitter was replaced. In contrast to the fish in the downstream study section, the pattern of the female in the upstream section was complex and appeared to have been disrupted by a period of sharply lower water temperature (figs. 6 and 28). The female made several upstream movements, paused, and then moved downstream. She repeated the pattern several times before moving upstream again, then finally moving downstream and remaining stationary. Because this fish did not follow the characteristic apex model, the determination of the spawning location is problematic.

Although a number of factors could explain the disrupted pattern of movement of this fish, an examination of telemetry and environmental data indicates that the disrupted pattern may be related to rapid, large fluctuations (greater than $5^{\circ} \mathrm{C}$ ) in water temperature during the pre-spawn migratory phase (fig. 29). In particular, a $4{ }^{\circ} \mathrm{C}$ decrease in water temperature on May 9-11, 2008, is associated with a pause in migration, and decreasing temperatures on May 24 and May 28, 2008, are associated with a reversal in migration direction. It also is notable that these temperature decreases were coincident with a significant decrease in air temperature, rather than being related to either Gavins Point Dam releases or inflows from tributaries (fig. 29). The May 9, 2008, migration pause occurred during steady to slightly dropping discharges at Yankton, South Dakota, and Sioux City, Iowa, and steady to slightly increasing water temperature at Yankton. Allowing for a 1-day lag, the $4{ }^{\circ} \mathrm{C}$ water-temperature decrease at Sioux City, Iowa, is coincident with a $5{ }^{\circ} \mathrm{C}$ air temperature decrease unrelated to discharge. A discharge pulse from May 18-19, 2008, from Gavins Point Dam had little to no apparent affect on water temperatures just downstream at Yankton. The substantial water temperature decreases on May 24 and May 28, 2008, at Sioux City apparently also are unrelated to discharge variation, but are coincident with similar air temperature drops, allowing for slight lags. Hence, biologically significant water temperature changes on the Lower Missouri River can occur independent of discharge. Large temperature fluctuations close to spawning have been noted to disrupt spawning in other sturgeon species in hatcheries and in the field (Bruch and Binkowski, 2002; Paragamian and Wakkinen, 2002).

Data on pallid sturgeon spawning adults from 2007 and 2008 indicate that pallid sturgeon are spawning in the Lower Missouri River. Spawning is occurring at multiple locations, at different times, and under a wide range of geomorphic and hydraulic conditions. Although this study successfully documented spawning, it does not reveal whether or not spawning occurred under optimal conditions, whether or not enough eggs hatched, or whether or not young fish survived to contribute to the pallid sturgeon population.

Although no tagged pallid sturgeon in reproductive condition were documented using tributaries during any year, tagged wild pallid sturgeon moved short distances up some tributaries. Tagged pallid sturgeon were detected $21.1 \mathrm{~km}$ up the Big Sioux River, Iowa, and $2.9 \mathrm{~km}$ up the Grand River, Missouri. Both location events were associated with significant flood pulses in the tributaries. This would indicate that pallid sturgeon may make use of tributaries opportunistically for feeding when conditions allow. Repeated tracking efforts indicate that some non-reproductive, telemetry-tagged pallid sturgeon also may have used the Platte River, Nebraska, 
supporting previous tracking studies that indicated exchange of pallid sturgeon between the Platte and Missouri Rivers

(Peters and Parham, 2007).

Both sturgeon species are capable of long distance movements and move freely between the Missouri and Mississippi Rivers. Although shovelnose studies conducted in 2005-06 attempted to recollect gravid females as soon as possible after spawning, a number of individuals migrated quickly downstream after spawning and eventually were relocated more than $240 \mathrm{~km}$ downstream from the Missouri-Mississippi River confluence. One individual female reached her spawning apex on May 23, 2008, at Missouri River mile 169.7, and was relocated on July 20, 2008, more than $340 \mathrm{~km}$ downstream from the confluence. The distances over which pallid sturgeon may migrate to spawn in the open river was illustrated by gravid females implanted in 2008. Spawning pallid sturgeon females moved 137-298 km upstream from their capture location before stopping to spawn. The three females from the downstream study section then migrated downstream 370-594 km into the Mississippi River after spawning. One pallid sturgeon in the Lower Missouri River has been observed to move more than 1,600 km, upstream and downstream distances combined, within an 18-month span. Documentation of long-range migrations may become more common with use of longer-lived telemetry tags and monitoring of pallid sturgeon throughout their entire, multi-year reproductive cycle.

\section{Early Life History}

In total, 150 larval Scaphirhynchus sturgeon (undifferentiated shovelnose and pallid sturgeon) and more than 100,000 other larval fishes were collected in 7,379 net-sets during 2006-07. Scaphirhynchus sturgeon larvae were collected in every sampled subsegment and in the Big Sioux and Platte Rivers at least once (table 3). Most were collected from late May through mid-June ( 96 percent), on inside bends ( 71 percent), near the riverbed ( 58 percent), and between river miles 738 and 776 (44 percent), which is between the confluence of the Vermillion and Big Sioux Rivers. A few larvae $(\mathrm{N}=6)$ were collected from the Missouri River in July and August. Only one was collected upstream from river mile 804 (confluence with the James River), and one was collected in the Platte River. No larvae were collected within the James River, Vermillion River, or Little Sioux River subsegments. Assuming that factors affecting the probability of capturing larvae (including flow, turbidity, depth, and habitat complexity) were similar among samples, and that other factors affecting survival of embryos and larvae (including predation, disease, and contaminants) also were similar, relatively less spawning by Scaphirhynchus sturgeon seems to have occurred or has been less successful within these subsegments.

Scaphirhynchus larvae hatch at 7-9 $\mathrm{mm}$ total length (Snyder, 2002), so larvae smaller than 10-mm total length were assumed to be 0 days post hatch. Based on incubation times of embryos and water temperatures in each segment, most spawning was estimated to occur between May 28, 2006 and June 18, 2006, and May 18, 2007 and June 18, 2007; spawning occurred on a more limited basis before and after those time periods (Simpkins and LaBay, 2007). In 2007, zerodays-post-hatch larvae were collected earlier in the Big Sioux River and segments downstream from the confluence with the Big Sioux River than in upstream areas (table 4). Consequently, spawning appeared to follow temperature gradients by occurring earlier in downstream segments and tributaries than in upstream segments.

Larvae that were $10-\mathrm{mm}$ total length and larger primarily were collected downstream from the Big Sioux River, and generally after smaller larvae had been collected in segments upstream from this location. Based on size-at-age relations, most of these larvae were estimated to be 1-3 days post hatch, whereas the largest specimen was estimated to be 5-6 days post hatch (Braaten and Fuller, 2007). Origins of these larvae were estimated based on drift-rate models (Braaten and others, 2008) for each species and vertically averaged water velocities existing at similar flows at USGS streamflow-gaging stations in each segment. Predictions generally coincided with collections of zero-days-post-hatch larvae.

After establishing that the drift-rate models developed for sturgeon in the Upper Missouri River accurately predicted drift of day-zero larvae based on mean reach velocities, we used those models to estimate where shovelnose sturgeon and pallid sturgeon collected in 2006-07 would have transitioned into benthic habitats (table 5). If larvae collected in our 2006-07 samples were shovelnose sturgeon, they would have initiated transition to benthic habitats between river miles 245-623. Most of the larvae collected at our sites were predicted to make the transition between the Platte River and the Kansas River. Only the largest larvae, which likely originated from the Big Sioux River, potentially could transition to the benthic life stage in the Missouri River upstream from the Platte River; however, pallid sturgeon larvae would drift further downstream. The earliest the largest pallid sturgeon larvae would have transitioned to benthic habitats would be at river mile 378 (near the Kansas River). The remaining larvae would have made the transition between river mile 240 and several miles down the Mississippi River.

Our larval catch results for 2006-07 can be generalized to indicate potential for larvae to settle within the Lower Missouri River mainstem. Using a range of reach-average current velocities (Reuter and others, 2008) and ranges of days to settling for shovelnose and pallid sturgeon (Kynard and others, 2002; Braaten and others, 2008) result in calculated potential drift distances of 304-1,770 km (table 6). Drifting in a hydraulically-variable river, larvae would be expected to disperse as they drift, resulting in a distribution of drift distances for any specific cohort; this analysis does not include variability that would result from longitudinal dispersion of larvae. Because the calculation is based on measured mean velocities at the reach scale, it incorporates some effects of spatial variability of velocity, but the calculation may underestimate drift distance if drifting larvae are preferentially 


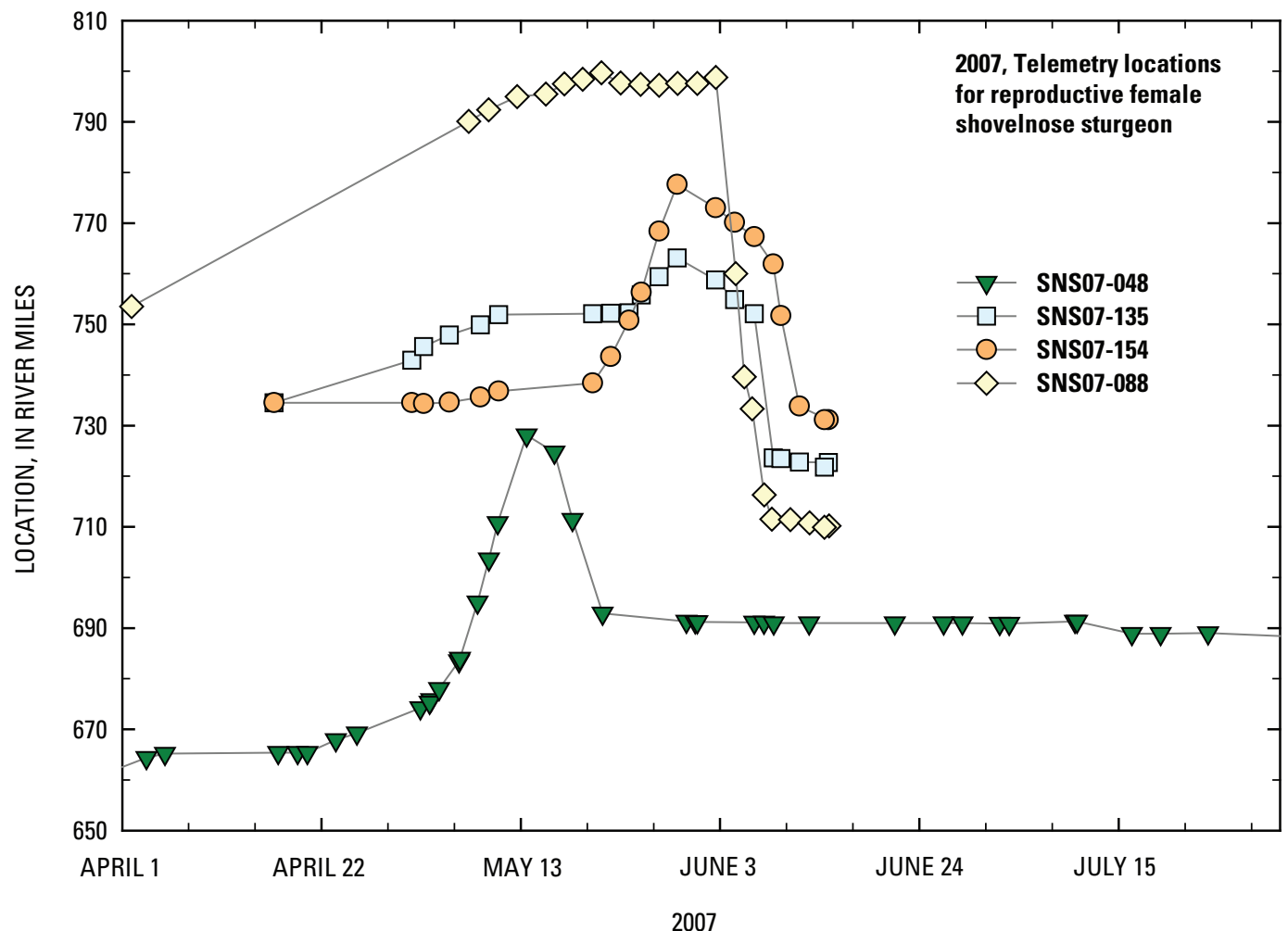

Figure 18. Telemetry locations for implanted reproductive female shovelnose sturgeon, SNS07-048, SNS07-135, SNS07-154, and SNS07-088. Fish were implanted in reproductive condition in 2007, recaptured later the same year, and determined to have spawned.

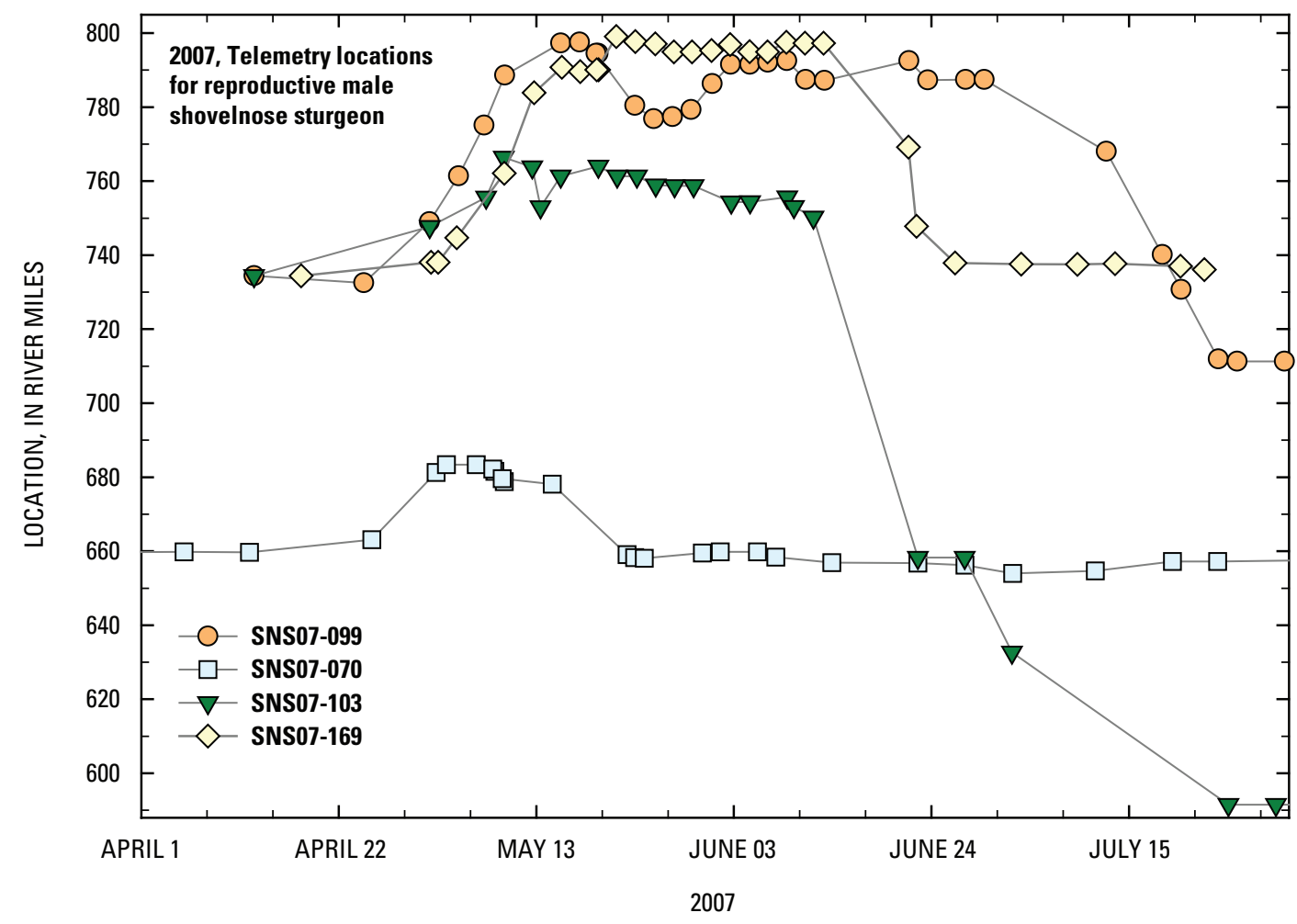

Figure 19. Telemetry locations for implanted reproductive male shovelnose sturgeon, SNS07-099, SNS07070, SNS07-103, and SNS-169. Fish were implanted in reproductive condition. 
Table 3. Frequency of larval sturgeon collected with time in river sub-segments ${ }^{1}$ and major tributaries in the Lower Missouri River.

$\left[\mathrm{RM}\right.$, river mile; --, no data; - , no sampling $\left.{ }^{2}\right]$

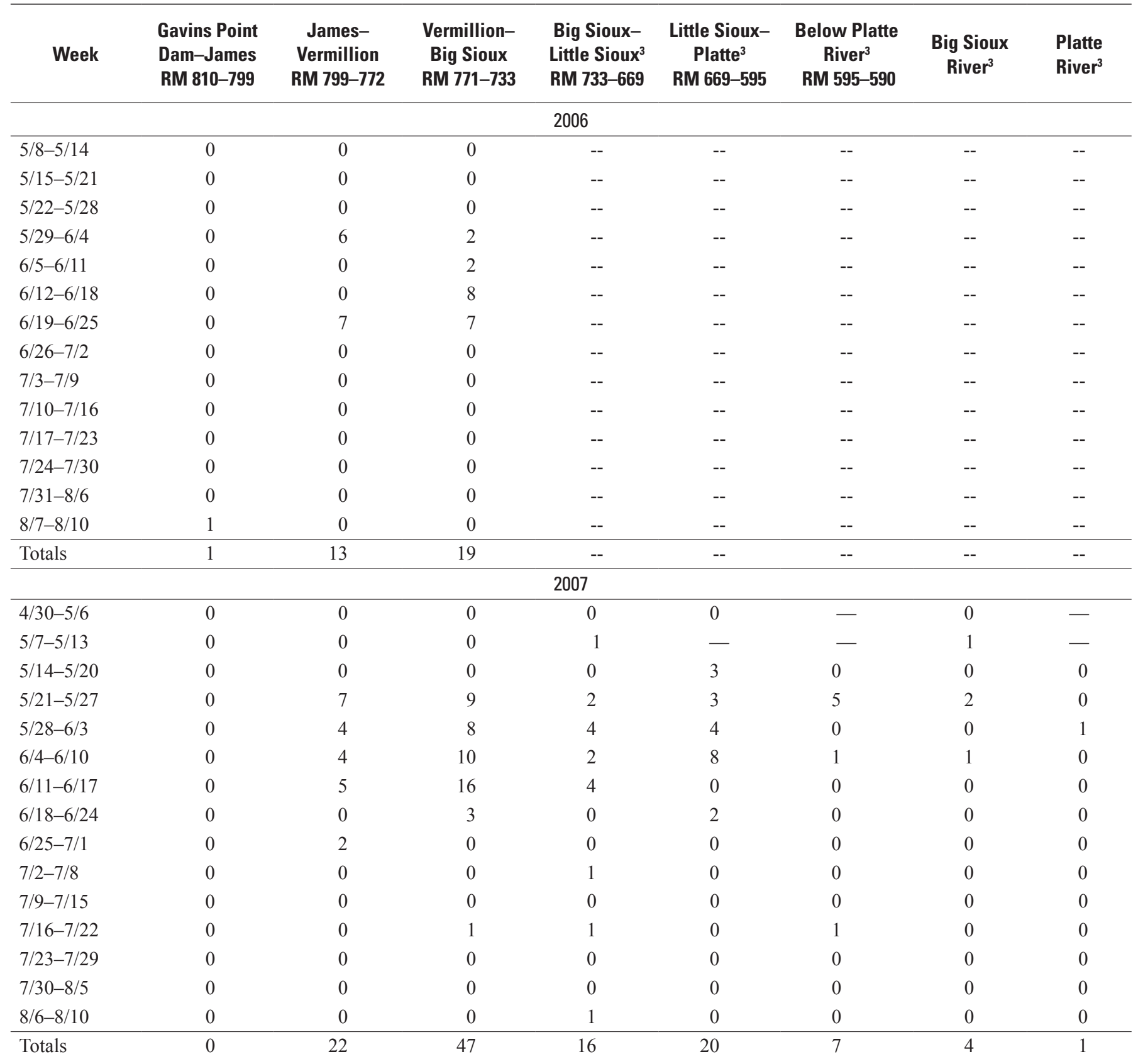

${ }^{1}$ River sub-segments were established between confluences of major tributaries.

${ }^{2}$ Sampling did not occur during these times because of safety reasons associated with high flows and drifting debris.

${ }^{3}$ Segments below river mile 733 were not sampled in 2006. 
Table 4. Mean total length of sturgeon larvae collected with time in river sub-segments ${ }^{1}$ and major tributaries of the Lower Missouri River.

[RM, river mile; mm, millimeter; - , no sturgeon collected; --, no data; ( ), confidence intervals between parantheses]

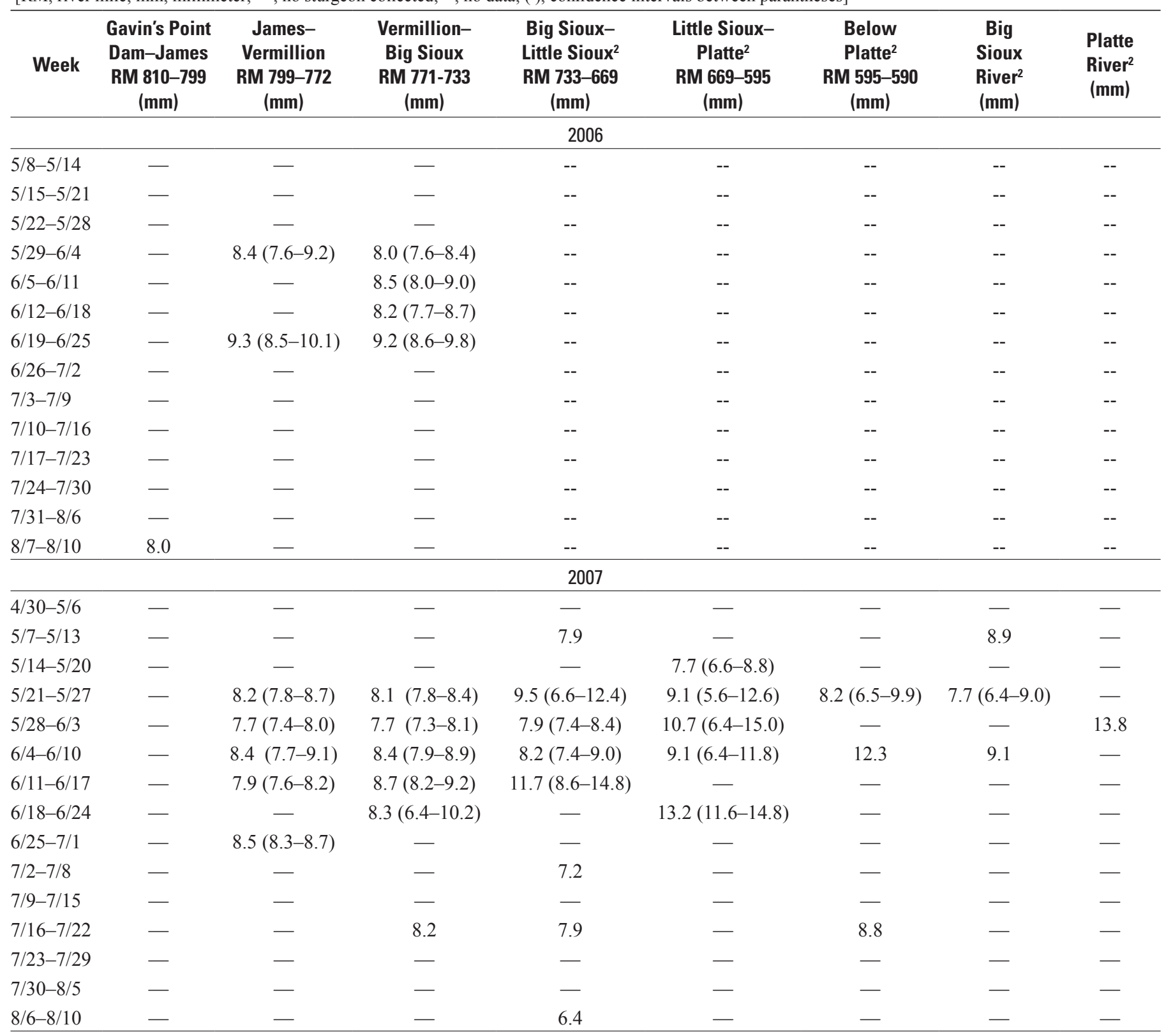

${ }^{1}$ River sub-segments were established between confluences of major tributaries.

${ }^{2}$ Segments below river mile 734 were not sampled in 2006. 


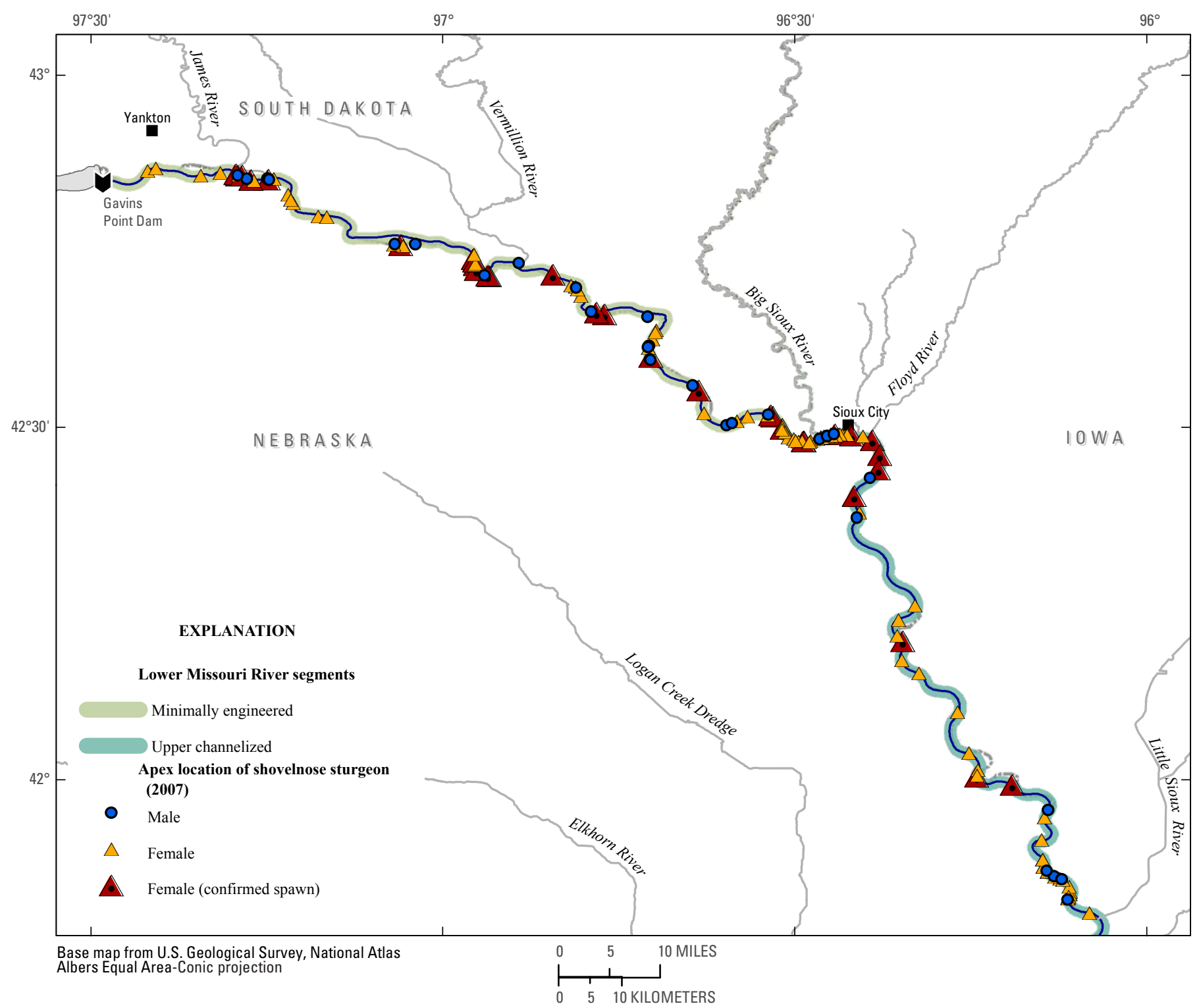

Figure 20. Maximum upstream location (apex) of telemetry-tagged male and female shovelnose sturgeon and apex locations of female sturgeon that were later recaptured and confirmed to have spawned in the upper study segment. All fish were in reproductive condition when implanted.

concentrated in the thalweg where velocities would be higher, as indicated by recent studies (P.J. Braaten, U.S. Geological Survey, oral commun., June 2009). Nevertheless, these broad calculations document the potential for long drift distances. Larvae that are spawned over much of the Lower Missouri River have the potential to drift into the Middle Mississippi River. Pallid sturgeon larvae are unlikely to settle in Missouri River habitats unless velocities are low, temperatures (and maturation rates) are high, and the fish spawn in the uppermost reaches of the river. Even for pallid sturgeon that might spawn just downstream from Gavins Point Dam (an event that has not been documented), typical drift rates would transport larvae downstream from Kansas City before they settle. This result has implications for where restoration of habitats intended for larval rearing would be most effective on the Lower Missouri River.

Drift rate and drift distance could be substantially smaller for shovelnose sturgeon, as they may spawn in lower-velocity tributaries; they drift at rates slower than reach-average current velocity; and they mature to settling stage in a shorter time frame than pallid sturgeon (Braaten and others, 2008). Hence, the Lower Missouri River may be more likely to retain and recruit shovelnose sturgeon compared to pallid sturgeon. 
Table 5. Collections of sturgeon larvae greater than 10 millimeters total length and estimated ages and origins with information about corresponding collections of day-0 larvae within or near estimated time of hatch and origins.

[mm, millimeters; MSR, ranges that extend into the Mississippi River; --, no data]

\begin{tabular}{|c|c|c|c|c|c|c|c|c|c|c|}
\hline \multirow{3}{*}{$\begin{array}{c}\text { Total } \\
\text { length } \\
(\mathrm{mm})\end{array}$} & \multirow{3}{*}{ Date } & \multirow{3}{*}{$\begin{array}{l}\text { River } \\
\text { mile }\end{array}$} & \multirow{3}{*}{$\begin{array}{c}\text { Age } \\
\text { (days) }\end{array}$} & \multirow{3}{*}{$\begin{array}{c}\text { Origin } \\
\text { (river miles) }\end{array}$} & \multicolumn{2}{|c|}{ Collection of day-0 larvae } & \multicolumn{4}{|c|}{$\begin{array}{c}\text { Habitat transition site }^{1} \\
\text { (river mile) }\end{array}$} \\
\hline & & & & & \multirow{2}{*}{ Date } & \multirow{2}{*}{ River mile } & \multicolumn{2}{|c|}{ Shovelnose sturgeon } & \multicolumn{2}{|c|}{ Pallid sturgeon } \\
\hline & & & & & & & Earliest & Latest & Earliest & Latest \\
\hline 11.1 & $5 / 22 / 07$ & 663 & $1.0-2.0$ & $715-756$ & $5 / 22 / 07$ & 2732 & 443 & 370 & 59 & MSR \\
\hline 10.5 & $5 / 23 / 07$ & 593 & $.5-1.0$ & $619-654$ & $5 / 22 / 07$ & 672 & 280 & 244 & MSR & MSR \\
\hline 11.0 & $5 / 24 / 07$ & 674 & $1.0-2.0$ & $725-767$ & $5 / 22 / 07$ & 772,736 & 458 & 397 & 70 & MSR \\
\hline 12.6 & $5 / 30 / 07$ & 596 & $2.0-3.0$ & $698-748$ & $5 / 25 / 07$ & 752 & 400 & 339 & 27 & MSR \\
\hline-- & -- & -- & -- & -- & $5 / 29 / 07$ & 736,739 & -- & -- & -- & -- \\
\hline 10.9 & $5 / 30 / 07$ & 599 & $1.0-2.0$ & $649-716$ & $5 / 29 / 07$ & 727 & 343 & 281 & MSR & MSR \\
\hline 11.9 & $5 / 31 / 07$ & 666 & $1.5-2.5$ & $730-802$ & $5 / 29 / 07$ & 794 & 449 & 381 & 87 & MSR \\
\hline 12.3 & $6 / 5 / 07$ & 592 & $2.0-3.0$ & $699-749$ & $6 / 3 / 07$ & $727,724,739,736$ & 415 & 347 & 40 & MSR \\
\hline 10.6 & $6 / 7 / 07$ & 595 & $1.0-1.5$ & $646-685$ & $6 / 6 / 07$ & 724,739 & 317 & 350 & MSR & MSR \\
\hline 15.4 & $6 / 14 / 07$ & 672 & $5.0-6.0$ & $821-893$ & -- & $3--$ & 620 & 566 & 375 & MSR \\
\hline 13.1 & $6 / 14 / 07$ & 672 & $3.0-4.0$ & $772-832$ & $6 / 12 / 07$ & 772 & 571 & 511 & 238 & MSR \\
\hline 10.7 & $6 / 15 / 07$ & 772 & $1.0-1.5$ & $795-821$ & -- & -- & 573 & 548 & 113 & MSR \\
\hline 10.3 & $6 / 15 / 07$ & 739 & $.5-1.0$ & $751-772$ & $6 / 12 / 07$ & 772 & 491 & 459 & 159 & MSR \\
\hline 12.6 & $6 / 19 / 07$ & 599 & $2.0-3.0$ & $695-768$ & $6 / 15 / 07$ & 772 & 435 & 380 & 103 & MSR \\
\hline-- & -- & -- & -- & -- & $6 / 18 / 07$ & 739 & -- & -- & -- & -- \\
\hline 13.8 & $6 / 21 / 07$ & 596 & $3.0-4.0$ & $752-799$ & $6 / 18 / 07$ & 739 & 492 & 432 & 160 & MSR \\
\hline 13.8 & $5 / 30 / 07$ & Platte & $3.0-4.0$ & -- & -- & -- & -- & -- & -- & -- \\
\hline
\end{tabular}

${ }^{1}$ Habitat transition site is the range of locations in river miles that shovelnose and pallid sturgeon larvae were predicted to transition from the drift into benthic habitats.

${ }^{2}$ From Big Sioux River.

${ }^{3}$ Since no larvae were collected above river mile 799, this larvae likely came from the Big Sioux River. Larvae within a day of the age range were captured below the Big Sioux River, though not in the Big Sioux River.

\section{Habitat Dynamics, Availability, and Selection}

Habitat assessments included characterizations of the variability related to varying discharge, variability related to erosion and deposition, variability of the habitat framework along the river, and evaluation of habitats selected by adult sturgeon. Habitat selection is a measure of affinity for a suite of physical conditions compared to all habitat conditions available within a river reach.

\section{Habitat Dynamics}

Hydrodynamic modeling in the four intensive reaches demonstrated the utility of hydrodynamic modeling in exploring habitat structure as a function of discharge. Areas of many of the habitat types were insensitive to discharge changes that would be involved in pulsed-flow modifications (Jacobson and others, 2009b). Among habitat metrics that were explored, zones of convergent flow were identified as areas that most closely correspond to spawning habitats of other sturgeon species, as identified in the scientific literature, and that are consistent with sparse data on pallid sturgeon spawning locations in the Lower Missouri River (described in preceding sections). Areas of convergent flow varied little with discharges that would be associated with spring pulsed flows, and relations with discharge changed negligibly because of erosion and deposition in the reaches between 2006 and 2007.

Other habitat measures demonstrate how physical habitat varies with discharge and among the four reaches. Wake habitats, defined by areas of relatively high velocity gradients, seem to correspond with migration pathways of adult pallid sturgeon. Habitats with low Froude number correspond to low energy areas that may accumulate passively transporting particles, organic matter, and larval fish. Among the modeled reaches, the Yankton, South Dakota, reach had substantially longer water residence time for equivalent flow exceedances than the other three modeled reaches. Longer water residence times result from greater flow resistance in the relatively wide, shallow channel, and may be associated with longer residence times of passively transported particulate materials and drifting larvae (Jacobson and others, 2009b). 
Table 6. Calculated river mile at which pallid sturgeon larvae would settle out from drift, based on 9, 13, and 17 days drift time (Kynard and others, 2002; Braaten and others, 2008) and reach-average velocities of 0.7 and 1.2 meters per second (Reuter and others, 2008).

[-, larvae would drift out of the Lower Missouri River]

\begin{tabular}{|c|c|c|c|c|c|c|c|c|}
\hline \multirow[b]{3}{*}{$\begin{array}{l}\text { Spawning } \\
\text { river mile }\end{array}$} & \multicolumn{8}{|c|}{ Reach-average velocity, meters per second } \\
\hline & \multicolumn{2}{|c|}{5 days } & \multicolumn{2}{|c|}{9 days } & \multicolumn{2}{|c|}{13 day } & \multicolumn{2}{|c|}{17 days } \\
\hline & 0.7 & 1.2 & 0.7 & 1.2 & 0.7 & 1.2 & 0.7 & 1.2 \\
\hline${ }^{1} 811$ & 622 & 487 & 471 & 228 & 320 & - & 168 & - \\
\hline 800 & 611 & 476 & 460 & 217 & 309 & - & 157 & - \\
\hline 750 & 561 & 426 & 410 & 167 & 259 & - & 107 & - \\
\hline 700 & 511 & 376 & 360 & 117 & 209 & - & 57 & - \\
\hline 650 & 461 & 326 & 310 & 67 & 159 & - & 7 & - \\
\hline 600 & 411 & 276 & 260 & 17 & 109 & - & - & - \\
\hline 550 & 361 & 226 & 210 & - & 59 & - & - & - \\
\hline 500 & 311 & 176 & 160 & - & 9 & - & - & - \\
\hline 450 & 261 & 126 & 110 & - & - & - & - & - \\
\hline 400 & 211 & 76 & 60 & - & - & - & - & - \\
\hline 350 & 161 & 26 & 10 & - & - & - & - & - \\
\hline 300 & 111 & - & - & - & - & - & - & - \\
\hline 250 & 61 & - & - & - & - & - & - & - \\
\hline 200 & 11 & - & - & - & - & - & - & - \\
\hline 150 & - & - & - & - & - & - & - & - \\
\hline 100 & - & - & - & - & - & - & - & - \\
\hline 50 & - & - & - & - & - & - & - & - \\
\hline
\end{tabular}

${ }^{1}$ Gavins Point Dam, Nebraska

Morphodynamic responses in the four reaches varied considerably by reach and year (Elliott and others, 2009). The Yankton reach was the most stable during monthly and annual timeframes. The Kenslers Bend and Little Sioux reaches exhibited substantial amounts of deposition and erosion, although net change generally was low in both reaches. Total, or gross, geomorphic change was greatest in the Kenslers Bend reach. The Miami reach exhibited varying rates of deposition and erosion and low net change. The Yankton, Kenslers Bend, and Miami reaches experienced net erosion during the time that bracketed the managed May 2006 spring pulsed-flow event from Gavins Point Dam. The monitoring data indicate that flow pulses of the scale considered in design of the flow pulses (spring rises) on the Lower Missouri River are capable of transporting sediment in all four reaches and, therefore, have the potential to flush fine sediment from spawning substrate where hard substrate occurs at depth.

This confirms one of the roles attributed to spring pulsed flows by the Biological Opinion: that pulsed flows may be capable of conditioning spawning substrate (U.S. Fish and Wildlife Service, 2000; 2003). As described in this report, however, additional data indicate that areas of converging flow on outside bends are selected by pallid sturgeon for spawning.
Because substantial areas of these habitats constantly are flushed free of fine sediment, it is unlikely that the spring pulses are needed to condition this type of spawning habitat. Conditioning may be more important in supporting spawning if natural gravel-cobble deposits in mid-channel positions in non-channelized segments are superior for spawning success. Extensive gravel-cobble deposits of natural origin exist across the channel in the Yankton reach (Laustrup and others, 2007; Reuter and others, 2008), but spawning has not been documented there.

\section{Habitat Availability}

Habitats available to pallid sturgeon vary substantially along the $1,305 \mathrm{~km}$ of the Lower Missouri River. Unlike natural rivers, habitat quality and quantity in the highly altered Missouri River are controlled largely by the nearly independent interaction of flow regime and engineered channel morphology (Jacobson and Galat, 2006). Variation in these factors defines a template of existing habitat patches with variable suitability to support life-stage functions, including migration, feeding, spawning, larval drift, and overwintering. The distribution of hard, coarse substrate was hypothesized to be a 

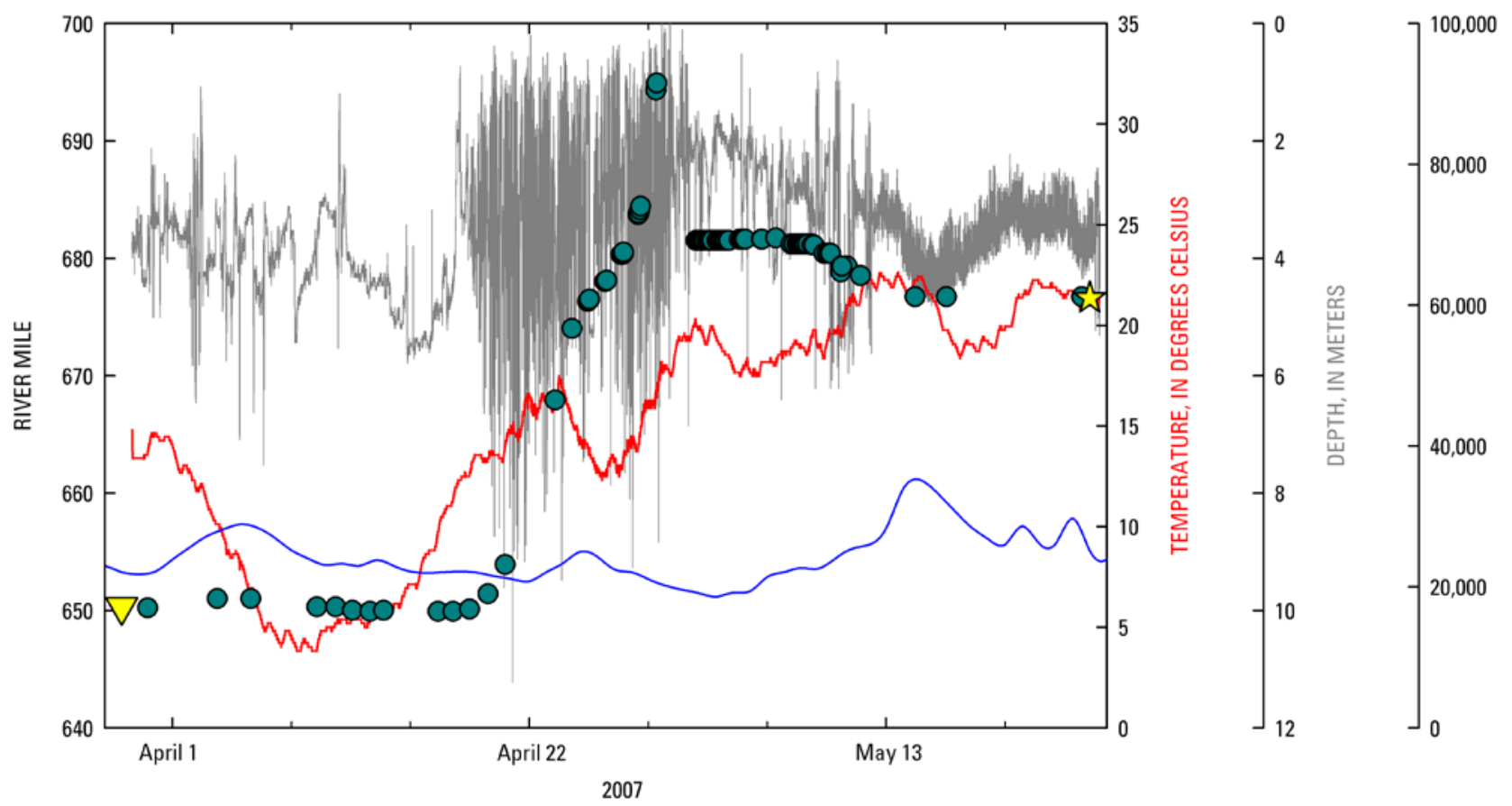

EXPLANATION

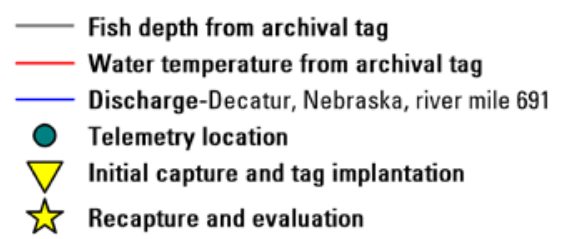

Figure 21. Depth and temperature recorded from data storage tag, discharge from the nearest upstream gage, and telemetry locations for implanted reproductive pallid sturgeon PLS07-007. Fish was implanted in reproductive condition, later recaptured, and determined to have spawned.

primary control on availability of spawning habitat; however, a substrate survey of the entire river determined that natural deposits, bedrock, and rock engineered structures provide substantial potential spawning habitat for nearly the entire length of the Lower Missouri River (Laustrup and others, 2007). To document the range of habitat conditions encountered by adult sturgeon during spawning migrations, 153 reach-scale hydroacoustic maps of sturgeon habitat from river mile 27.3 to 807.9 were used (Reuter and others, 2008; Reuter and others, 2009). Habitat maps, flow-regime data, sediment-transport data (Jacobson and others, 2009a), results of hydrodynamic modeling (Jacobson and others, 2009b), and results of habitat monitoring (Elliott and others, 2009) support a three-part longitudinal division of habitat availability (fig. 30).

- The upstream section (minimally engineered, Gavins Point Dam to Sioux City, Iowa) is characterized by a highly altered flow regime and the greatest channel complexity, indicated by high width to depth ratios. The upstream parts of this section near Gavins Point Dam are morphologically stable because of an armored bed and lack of sediment supply; however, the downstream parts of the section are narrower, and have adequate sediment supply to support high rates of annual geomorphic change. Normalized annual suspended sediment load is lowest in this section and is indicative of retention of sediment in the reservoir system. Although natural spawning substrate is abundant in this reach and channel complexity is high, low turbidity and associated water-quality conditions may limit habitat functions.

- The middle section (upstream channelized, Sioux City, Iowa, to Kansas City, Missouri) is characterized by a highly altered flow regime that recovers some variation moving downstream and the lowest channel complexity, as indicated by the low normalized width to depth ratio. This section also has been documented to have intra- and interannual channel morphological variation that is substantially greater than upstream and downstream sections (Elliott and others, 2009). Annual suspended sediment loads increase through this section. Engineered rock deposits provide abundant potential 


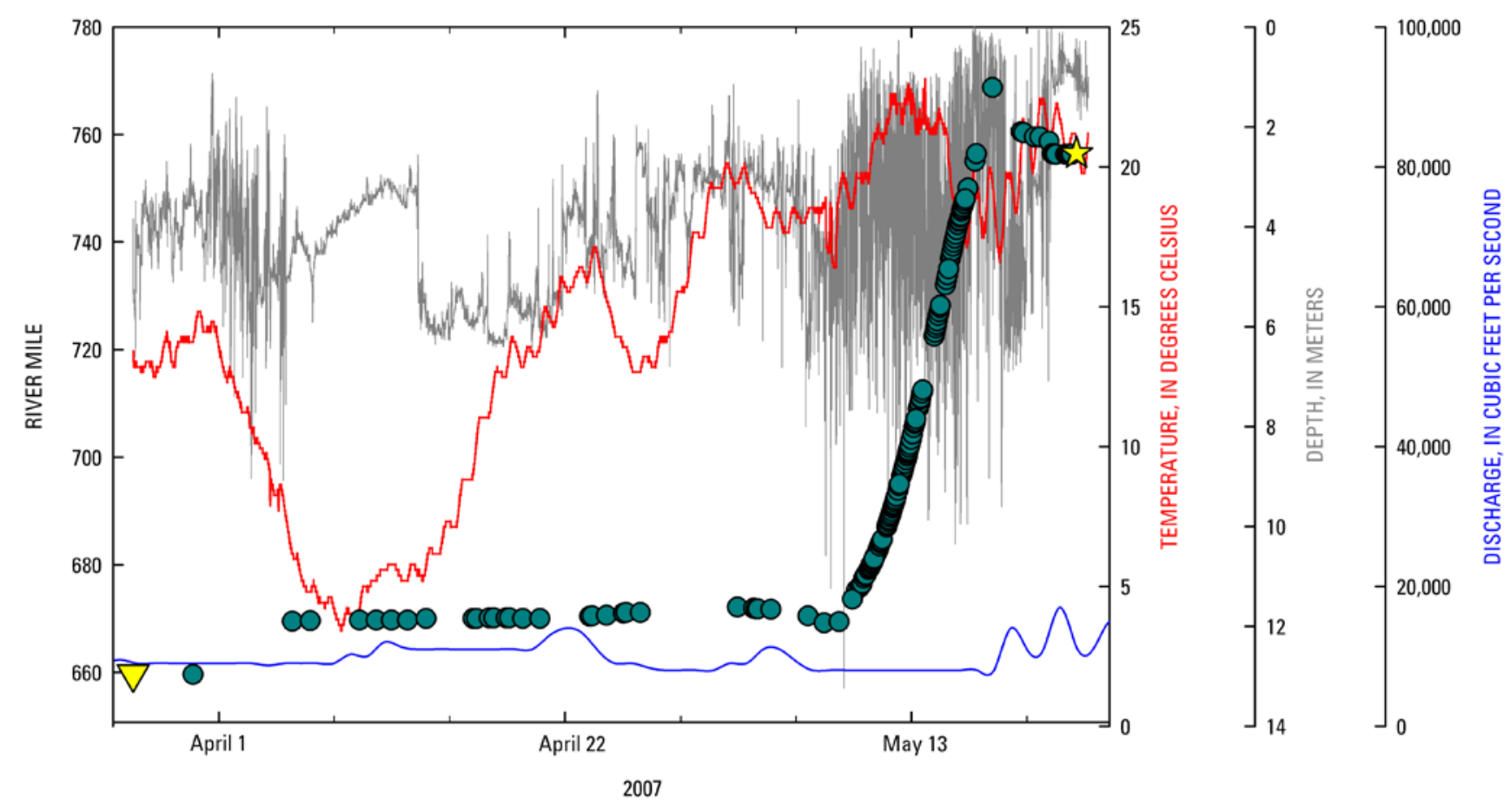

\section{EXPLANATION}

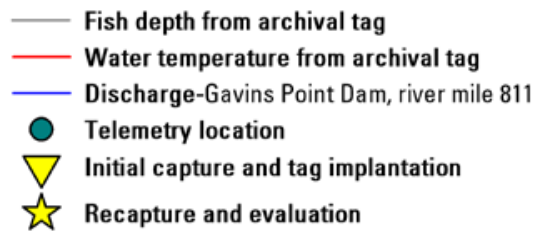

Figure 22. Depth and temperature recorded from data storage tag, discharge from the nearest upstream gage, and telemetry locations for implanted reproductive pallid sturgeon PLS07-004. Fish was implanted in reproductive condition, later recaptured, and determined to have spawned.

spawning substrate. The constricted, simple channel may present an energy barrier to upstream migrating sturgeon, and lack of marginal habitat probably limits retention of drifting larvae.

- The downstream section (downstream channelized, Kansas City, Missouri, to St. Louis, Missouri) shows a progressive downstream increase in flow-regime variability, and it maintains a normalized width to depth ratio intermediate between the minimally engineered and upstream channelized sections. Suspended sediment loads are highest here, although they amount to only 17 percent of pre-dam values (Jacobson and others, 2009a). Engineered rock deposits, bedrock exposures, and natural gravel-cobble deposits provide potential spawning substrate. Slow current velocity in marginal habitats and greater channel complexity may minimize migration energy and provide sites for larval retention.

\section{Habitat Selection}

Adult pallid and shovelnose sturgeon select characteristic physical habitat during and after their spawning migrations (Reuter and others, 2009). The selected habitats presumably indicate environmental conditions that are the most suitable - among those available - for migrating long distances and for feeding. Exploratory analysis of telemetric sturgeon locations within hydroacoustic habitat maps indicates that sturgeon select velocities $0.5-0.8$ meters per second $(\mathrm{m} / \mathrm{s})$ in the minimally engineered section, $0.4-1.0 \mathrm{~m} / \mathrm{s}$ in the upstream channelized section, and $0.3-1.0 \mathrm{~m} / \mathrm{s}$ in the downstream channelized section (fig. 31). Sturgeon avoid flat areas of the channel in all sections and tend to select bottom slopes of 2-20 degrees in the minimally engineered and upstream channelized segment; in the downstream channelized segment, sturgeon selected bottom slopes of 2-12 degrees. Sturgeon avoid velocity gradients (relative change in velocity per meter distance) of 0-2 percent per meter in all segments and select areas of relatively high velocity gradient: $0.6-3.0$ percent per 


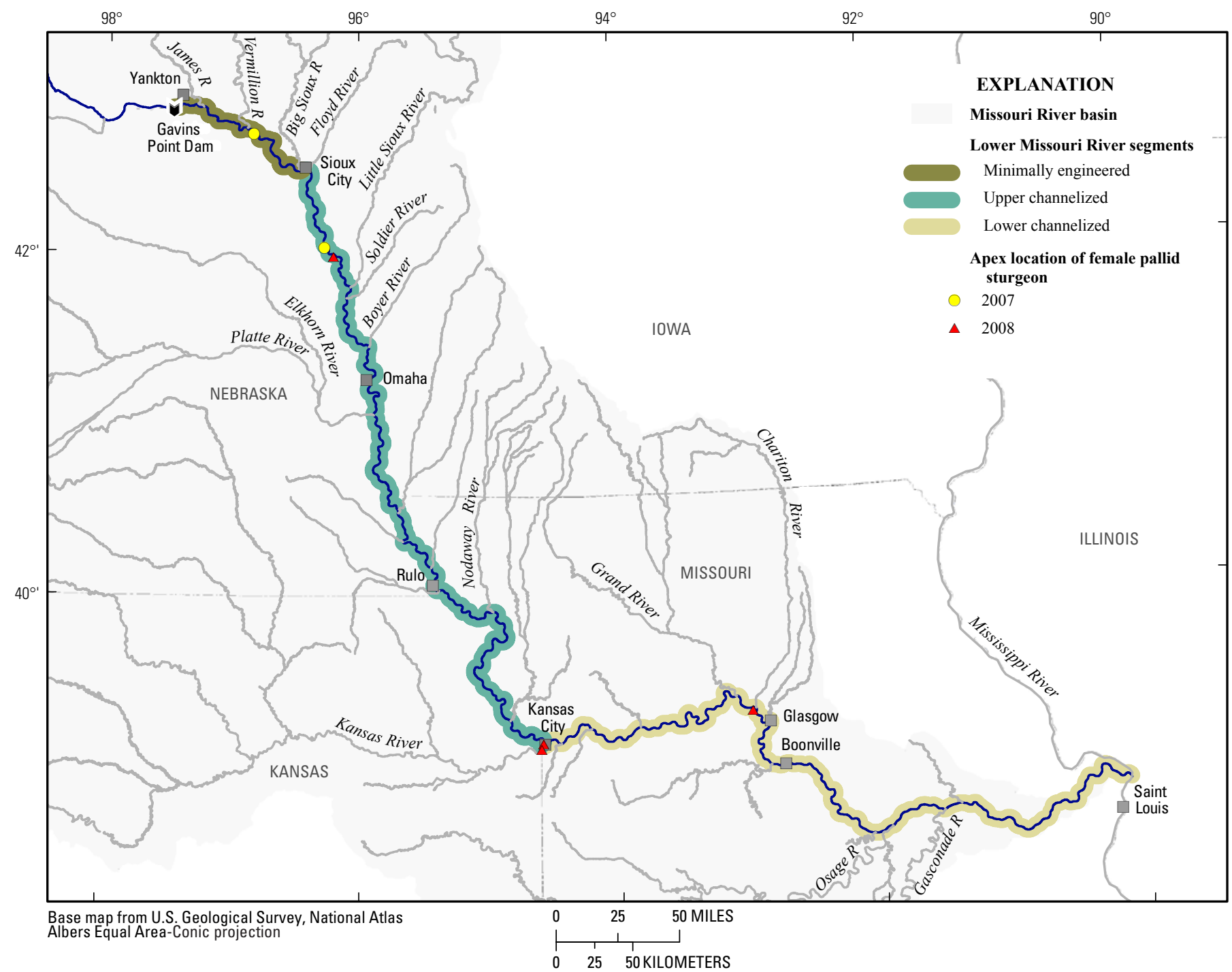

Figure 23. Lower Missouri River segments and maximum upstream location (apex) of telemetry-tagged female pallid sturgeon in 2007 and 2008. All fish were in reproductive condition when implanted, were tracked to their presumed spawning location, then recaptured, and determined to have spawned.

meter in the minimally engineered section, $0.8-4.0$ percent $/ \mathrm{m}$ in the upstream channelized section, and $0.6-3.2$ percent per meter in the downstream channelized segment. In the minimally engineered section, sturgeon selected areas with Froude numbers (a dimensionless number calculated as the velocity divided by square root of depth times gravitational constant) of $0.06-0.15$; in the upstream channelized section, they selected $0-0.15$; and in the downstream channelized section, they selected $0.03-0.15$.

Throughout the river, sturgeon selected strongly for substrate provided by engineered structures (revetment, wing dikes) and moderately for fine sediment (silt and mud); sturgeon avoided areas of transporting sand (table 7). Adult sturgeon strongly avoided shallow-water habitat (SWH, defined as $0-1.5 \mathrm{~m}$ deep, $0-0.60 \mathrm{~m} / \mathrm{s}$ velocity [U.S. Fish and Wildlife Service, 2003]) in the minimally engineered section, selected
SWH in the upstream channelized segment, and showed little selection or avoidance in the downstream channelized section (mapping of SWH was constrained in this study to depths greater than $0.6 \mathrm{~m}$ so area of shallow-water habitat $0-0.6$ $\mathrm{m}$ was not assessed). Sturgeon selection for depth also was less systematic along the river compared to other variables, perhaps because of interactions between depth selection and co-varying factors like turbidity (Reuter and others, 2009).

Detailed evaluation of habitat selection using discrete choice models demonstrates that direction and distance are inherent in sturgeon's association with physical habitat characteristics (T.W. Bonnot, University of Missouri, written commun., 2009). Specifically, based on shovelnose sturgeon locations and habitat maps (Reuter and others, 2008), sturgeon were shown to select slower velocities, shallower depths, and high variability in velocity and depth along a path between the 


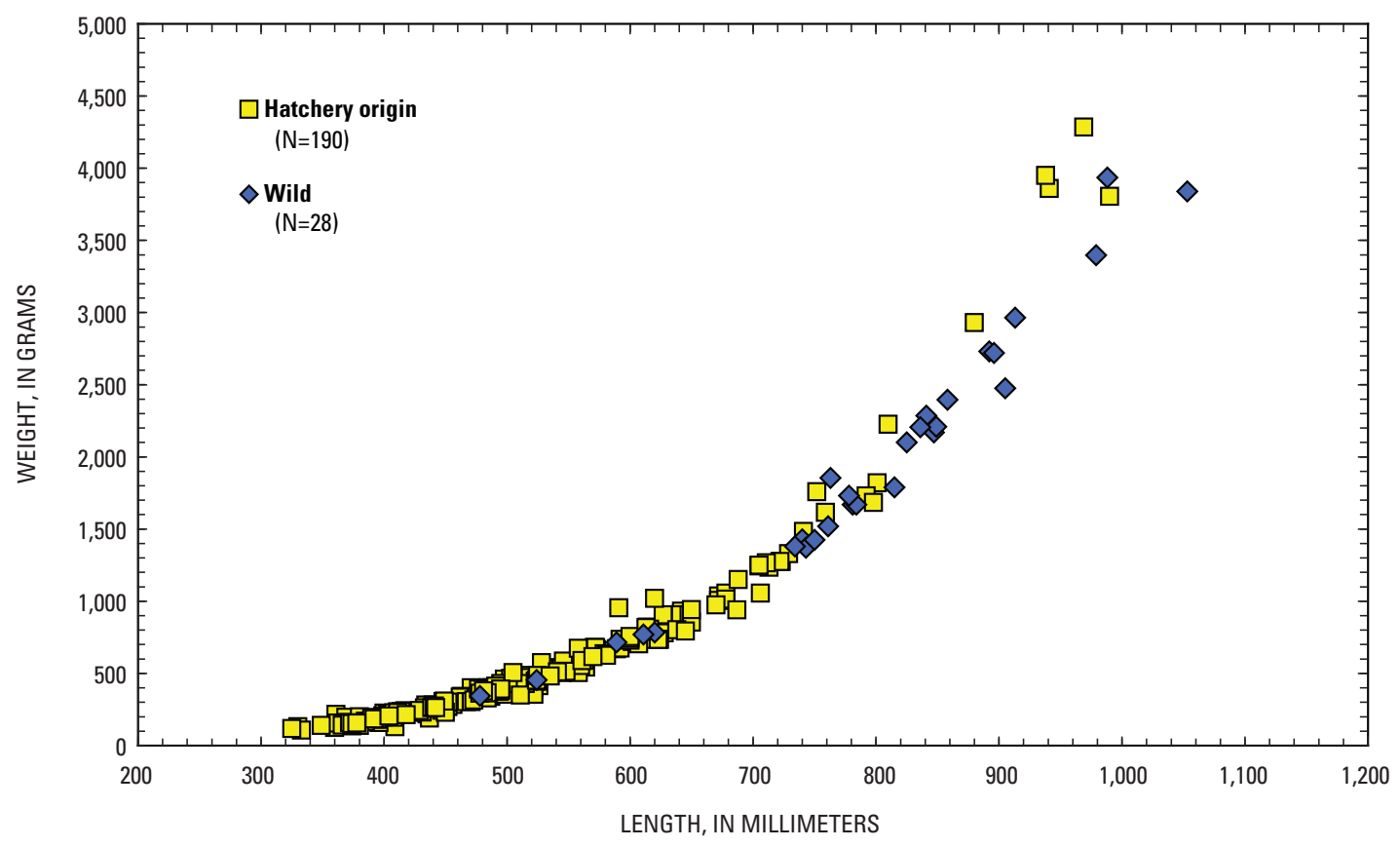

Figure 24. Length-weight relationship for wild and hatchery-origin pallid sturgeon collected during 2008 spring sampling efforts in both the upper and lower study segments.

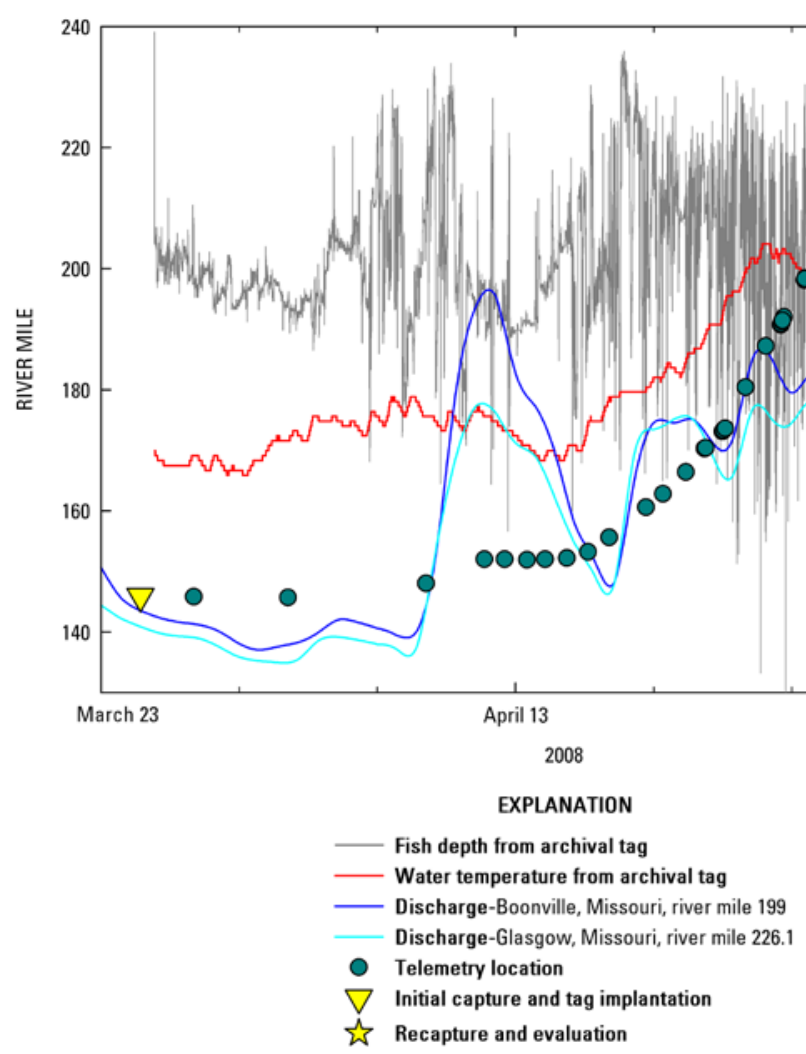

Figure 25. Depth and temperature recorded from data storage tag, discharge from the nearest upstream gages, and telemetry locations for implanted reproductive pallid sturgeon PLS08-004. Fish was implanted in reproductive condition, later recaptured, and determined to have spawned. 


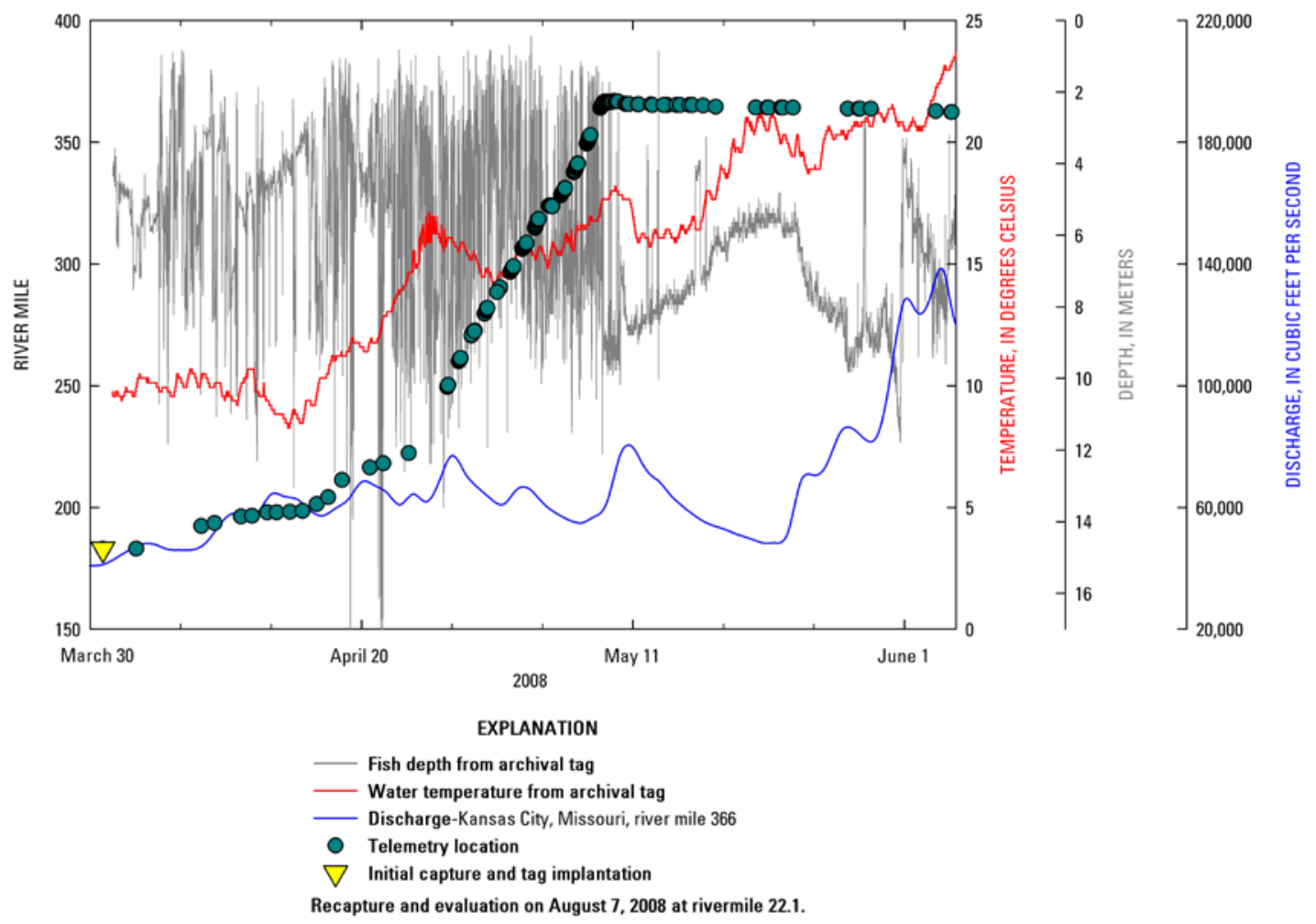

Figure 26. Depth and temperature recorded from data storage tag, discharge from the nearest upstream gage, and telemetry locations for implanted reproductive pallid sturgeon PLS08-008. Fish was implanted in reproductive condition, later recaptured, and determined to have spawned.

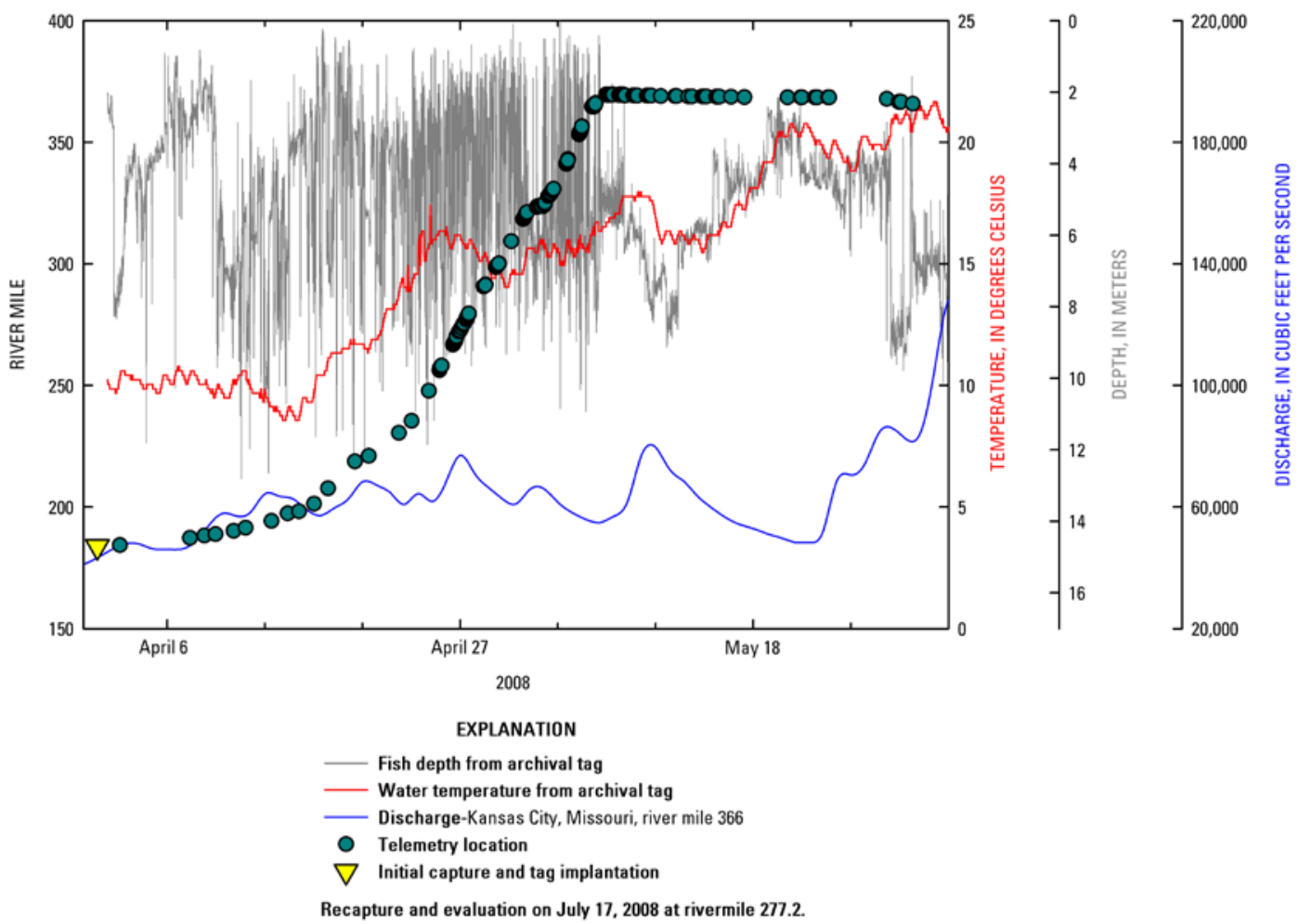

Figure 27. Depth and temperature recorded from data storage tag, discharge from the nearest upstream gage, and telemetry locations for implanted reproductive pallid sturgeon PLS08-009. Fish was implanted in reproductive condition, later recaptured, and determined to have spawned. 


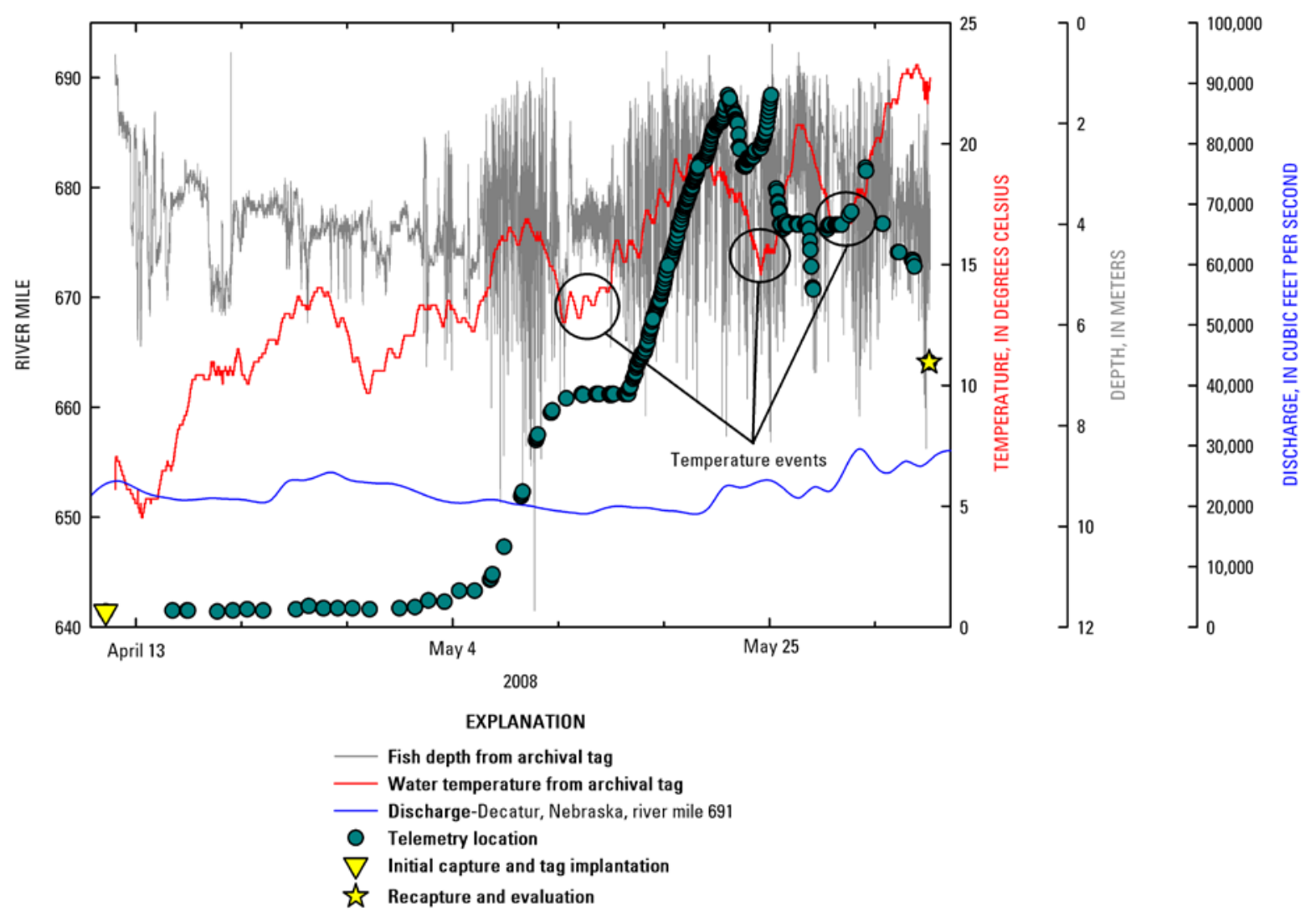

Figure 28. Depth and temperature recorded from data storage tag, discharge from the nearest upstream gage, and telemetry locations for implanted reproductive pallid sturgeon PLS08-014. Fish was implanted in reproductive condition, later recaptured, and determined to have spawned.

fish and the bank (fig. 32). Sturgeon also selected locations with a higher degree of small-scale, non-systematic spatial variation in velocity upstream and downstream. Although validation results for models in the upstream- and downstreamchannelized sections in 2005 demonstrated good predictability across those sections, differences in their model parameters are likely associated with the different geomorphologies of the two sections (see section on habitat availability, earlier in this report). The ability of models to predict across years (2005-07) was poor, which could be a function of interactions between discharge and morphology. Rates of annual geomorphic change also vary by section (Elliott and others, 2009). Although the importance of variability in surrounding depths and velocities is consistent across models, enough variation exists in models and their ability to predict across years and river sections to support the idea that specific use of the river by sturgeon varies temporally and longitudinally.

Analysis of depth-use patterns, documented through data storage tags (DSTs), lends support to the hypothesis that spawning sturgeon exhibit lower levels of depth variability in their swimming pattern during the spawning season, compared to non-spawning surgeon (Holan and others, 2009). These analyses confirm the idea that adult sturgeon select areas of complex gradients at the edges of the thalweg of the Lower
Missouri River during and after spawning migrations. Such areas are relatively small in area in the upstream engineered section of the river, Kansas River to Big Sioux River, indicating that favorable migration pathways may be limiting in this section.

In a few cases during 2006-08, intensive tracking was able to constrain probable spawning locations to reaches or patches (100's-1,000's of square meters). During 2008, three hatchery-origin pallid sturgeon were tracked to probable spawning locations on three separate bends of the Lower Missouri River located between river miles 230 and 269. Recapture of the female sturgeon indicated that they had dropped their eggs in or near these sites. The three sites were unremarkable for the channelized river: sturgeon were located in areas of convergent flow (zones of converging velocity vectors and increasing discharge per unit width) over coarse riprap on the outside of bends (fig. 33). Spawning in these common habitat patches may indicate that suitable spawning habitat is not a limiting factor for reproduction of the pallid sturgeon on the Lower Missouri River. Alternatively, spawning in these locations may be selection of the best available habitat, rather than optimal habitat, and spawning in such areas may not necessarily result in successful recruitment to older life stages. 

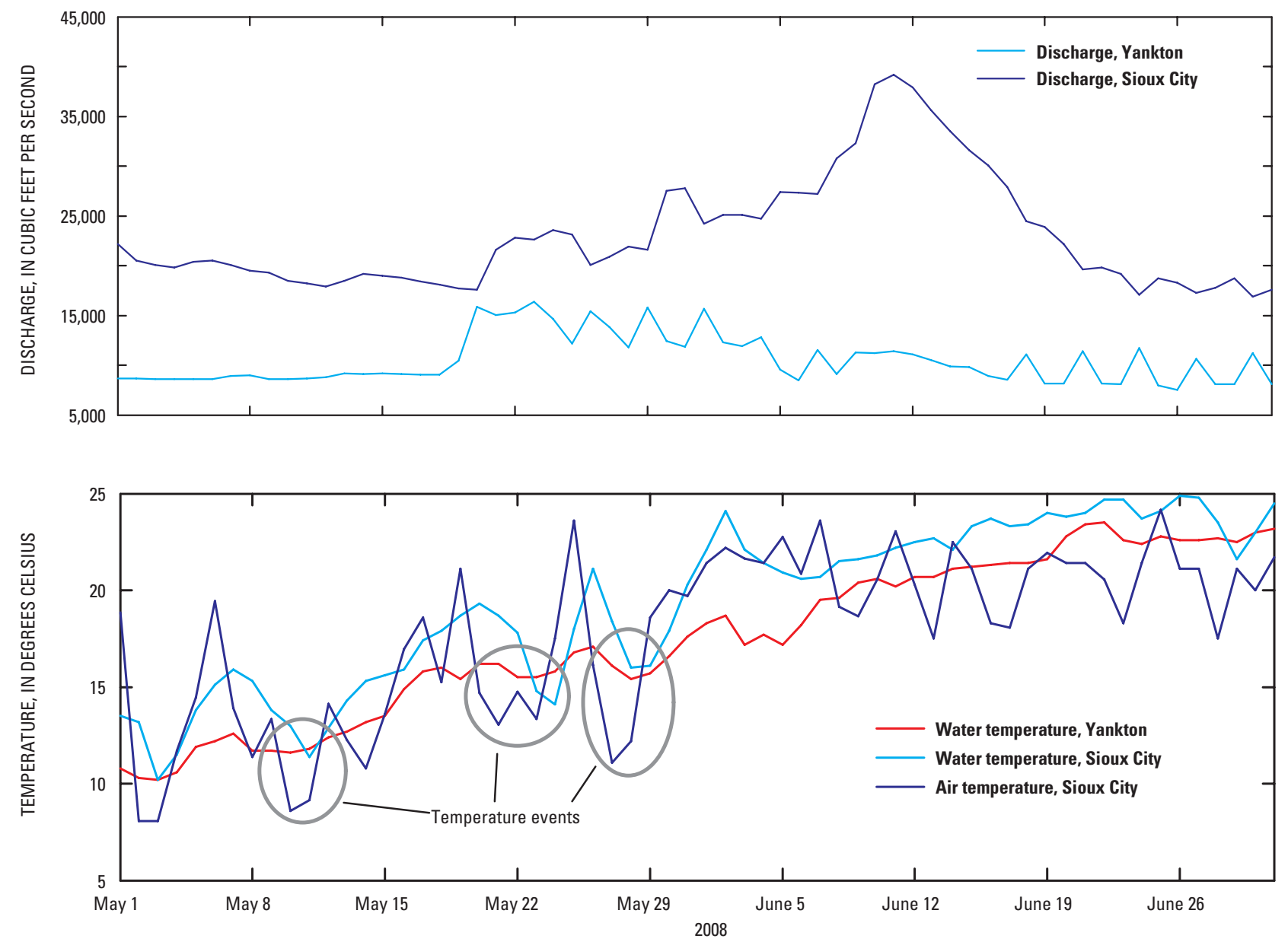

Figure 29. Discharge, water temperatures, and air temperatures from May to June, 2008. Temperature events associated with interruption in the migration of PLS08-014 show that water temperature declined at Sioux City, lowa as a result of an air temperature drop and was not associated with increased flow from Gavins Point Dam or tributaries.

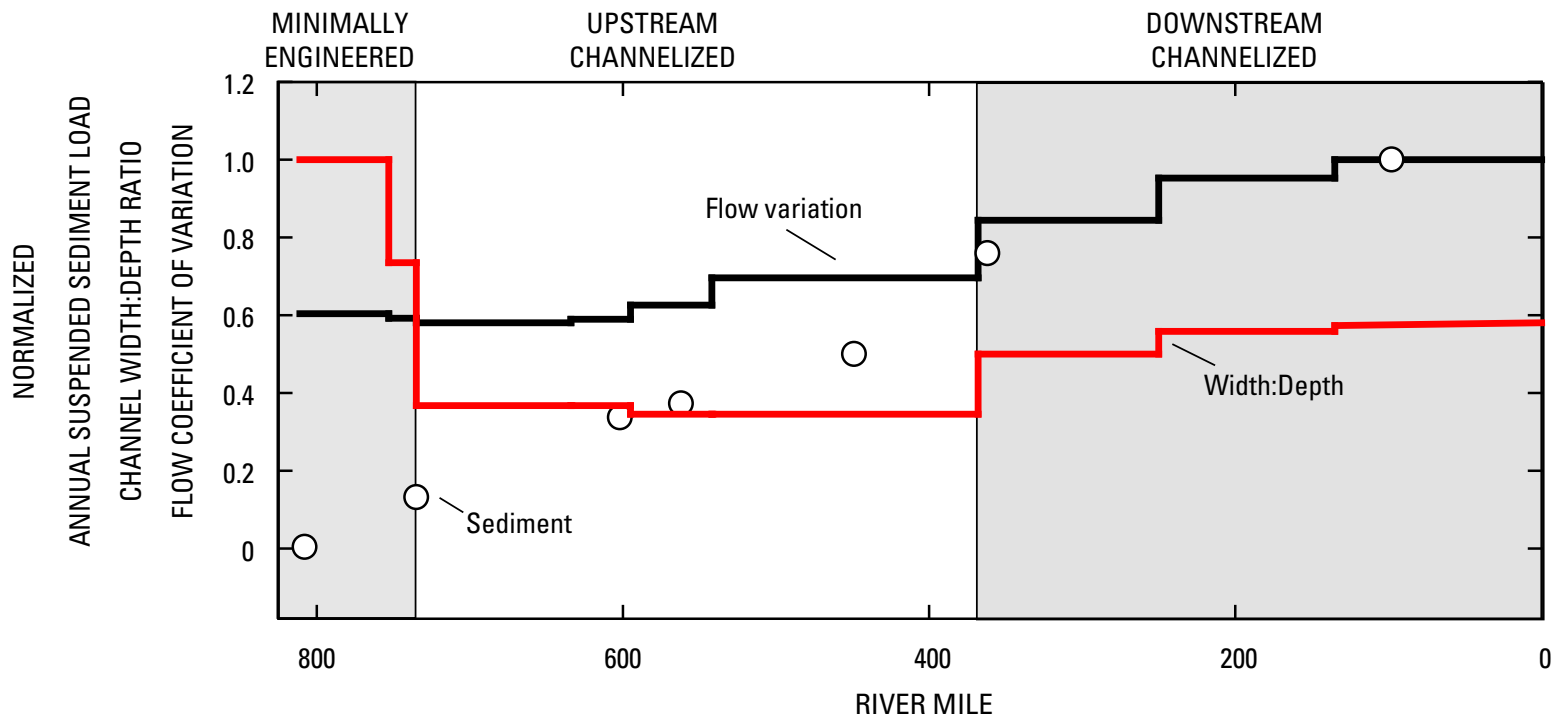

Figure 30. Plot of normalized habitat variables (daily flow coefficient of variation, channel width:depth ratio, annual suspended sediment load) by river mile showing variability in habitat-controlling factors along the Lower Missouri River and 3-part longitudinal division. Habitat variables are normalized by the maximum (most natural) value of each variable. 

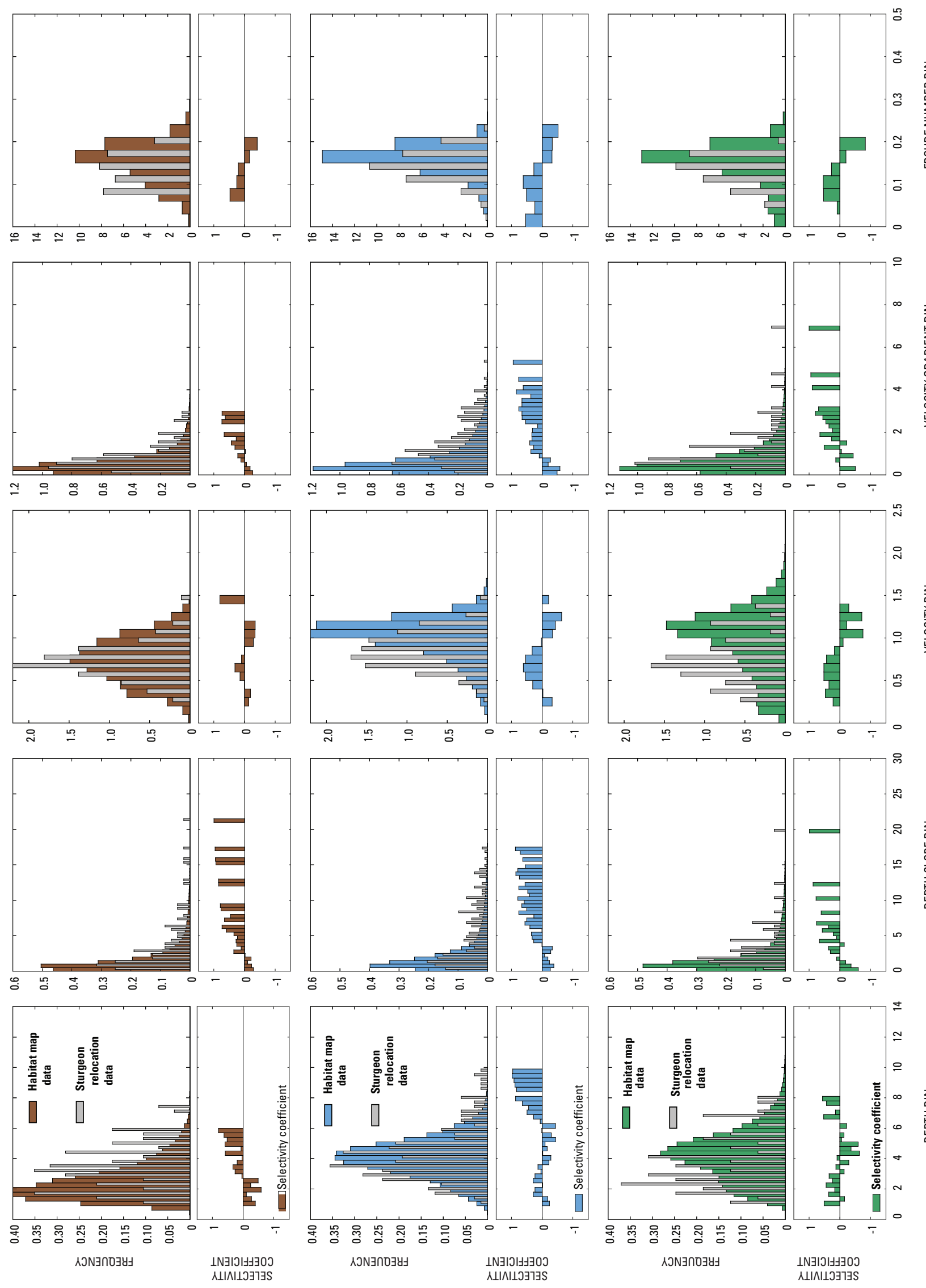

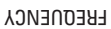
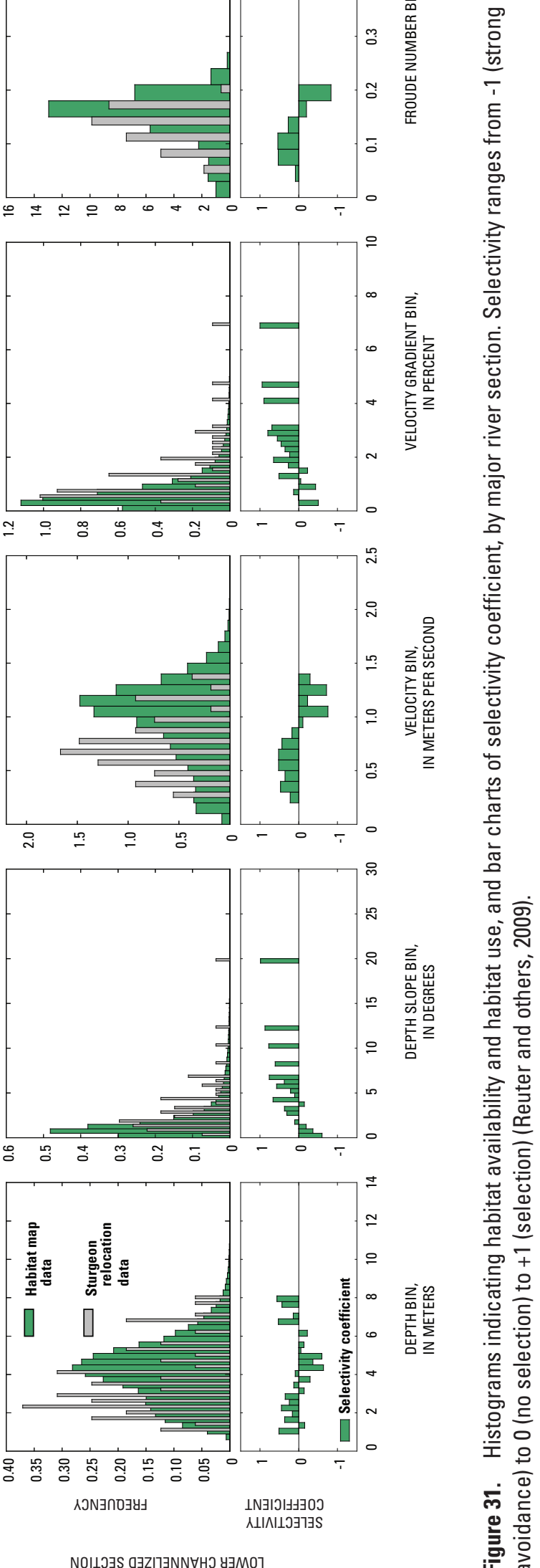

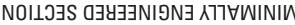

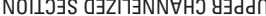

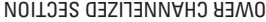

INヨIว।

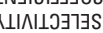

흠 옹 


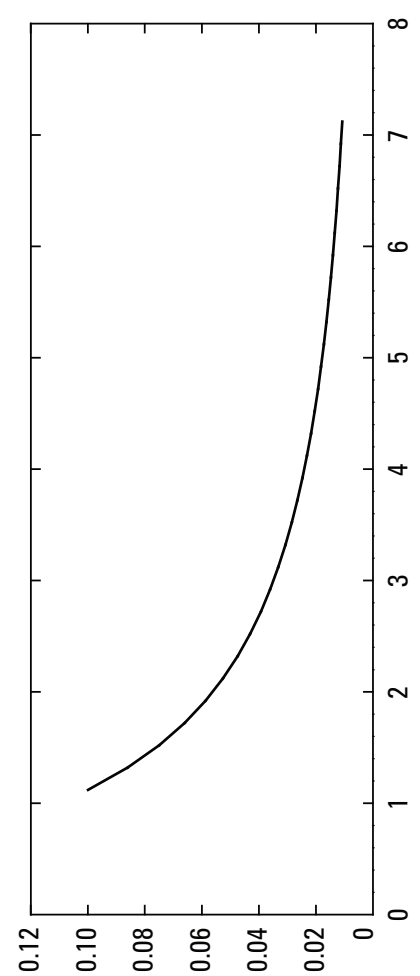

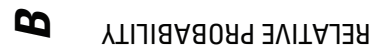
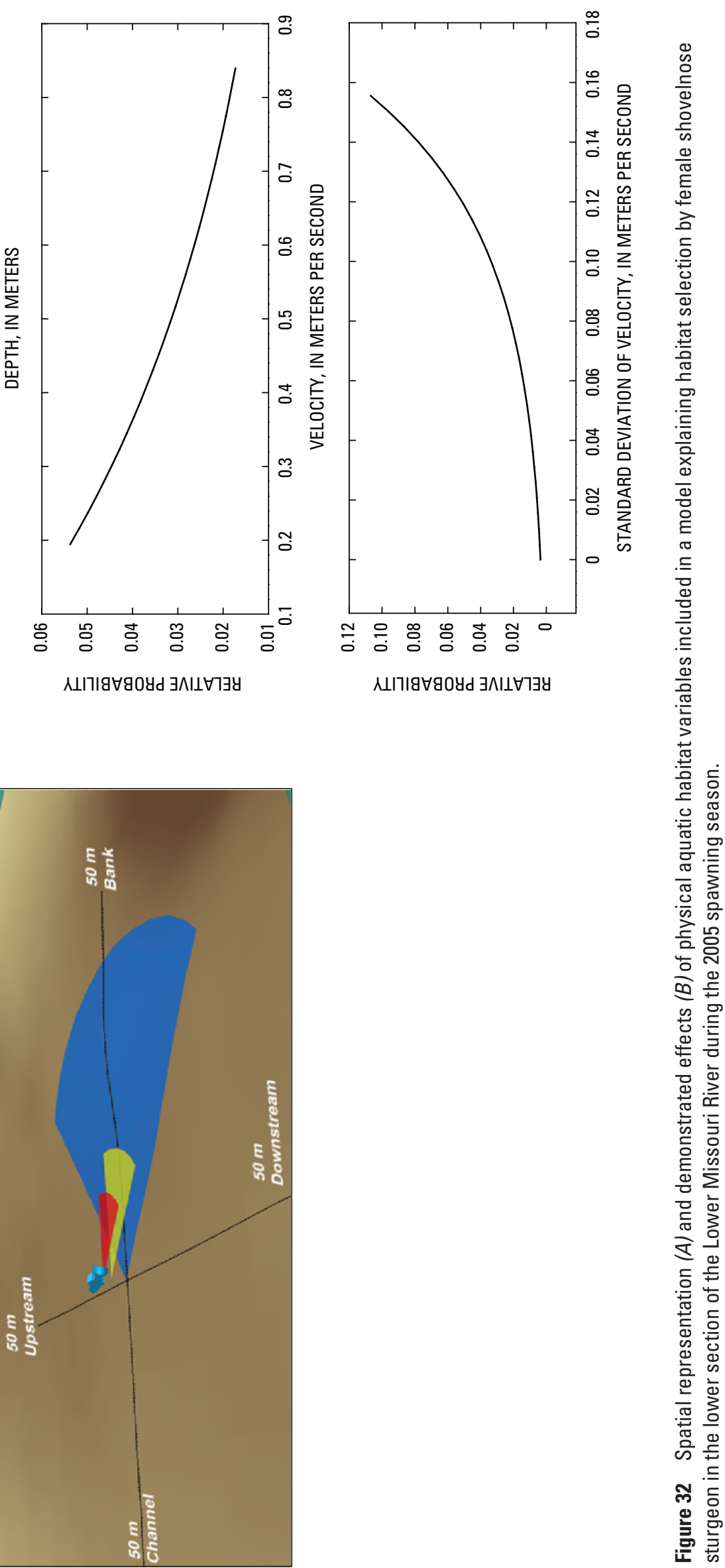


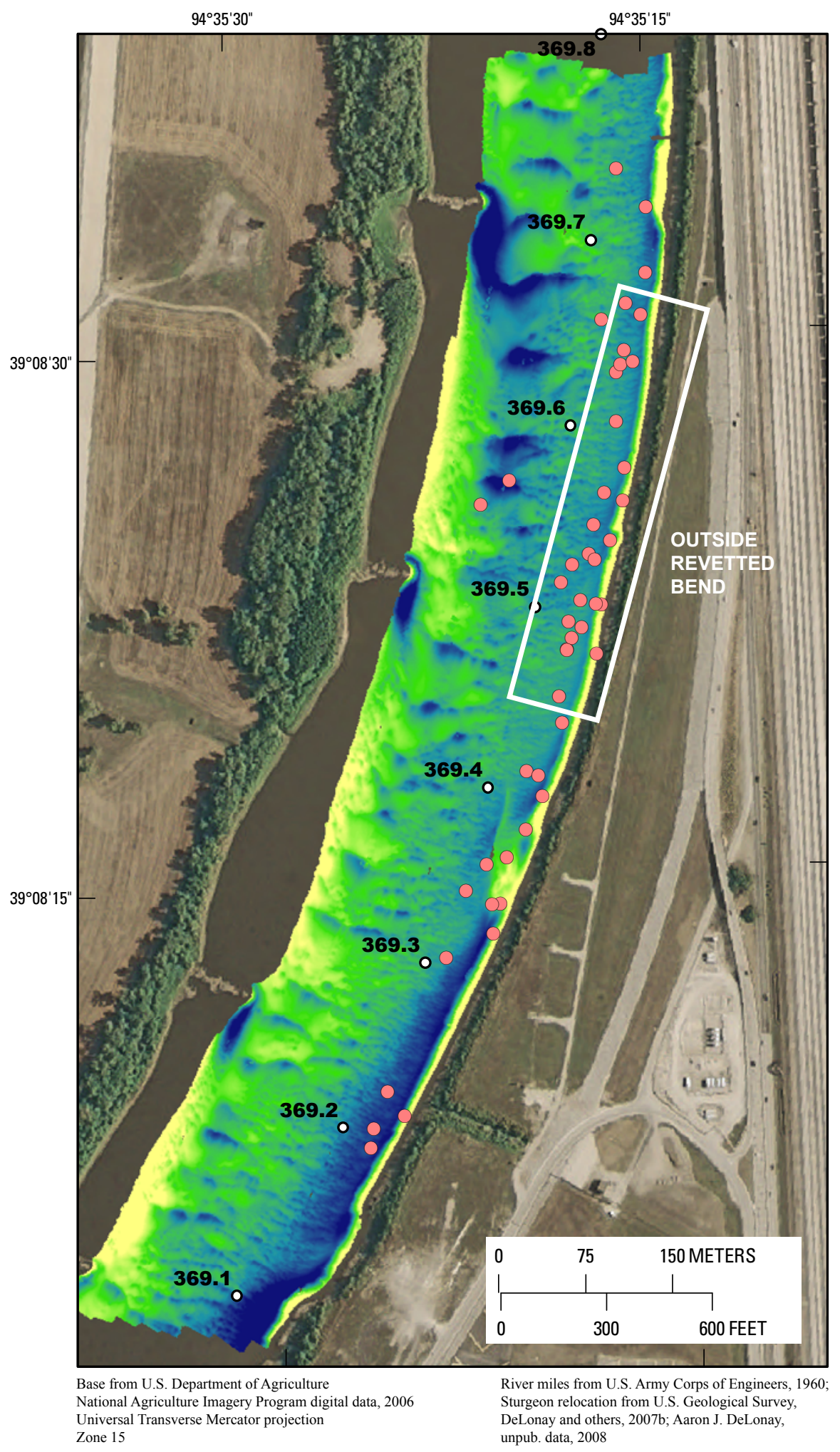

\section{EXPLANATION}

Depth, in meters

Deep

(maximum 12.6)

Shallow

(minimum 2.9)

Sturgeon relocation-

Relocations of

pallid sturgeon

PLS08-009

(acoustic tag 575)

between May 7 and

May 8, 2008

369.6

River-mile markerNumber is distance upstream from the junction with the Mississippi River, in miles

Discharge on the date of mapping (2008-05.13) at the Kansas City, Missouri, streamflow-gaging station: 68,600 cubic feet per second

Figure 33. Multibeam bathymetric map of spawning location of PLS08-004 near river mile 369.5 in 2008. 
Table 7. Summary of categorical data by river section, including percentage of map area, percent of relocations, and Ivlev's selectivity coefficient.

\begin{tabular}{|c|c|c|c|c|c|c|c|c|c|c|c|}
\hline \multirow[b]{2}{*}{ River section } & \multicolumn{5}{|c|}{ Generalized substrate } & \multicolumn{2}{|c|}{$\begin{array}{c}\text { Shallow-water } \\
\text { habitat }\end{array}$} & \multicolumn{4}{|c|}{ Terrain classification } \\
\hline & 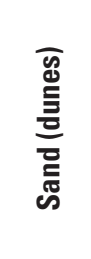 & 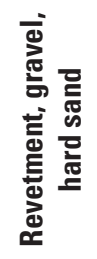 & 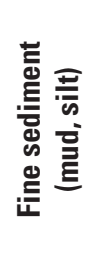 & 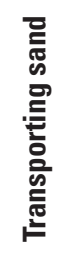 & 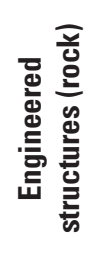 & 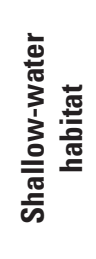 & 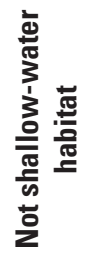 & $\frac{\pi}{\pi}$ & $\frac{\Xi}{\text { 음 }}$ & $\begin{array}{l}\overleftarrow{\mathscr{d}} \\
\text { 屯े }\end{array}$ & 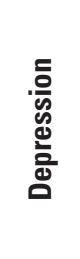 \\
\hline \multicolumn{12}{|c|}{ Percentage of map area } \\
\hline Minimally engineered & 82.1 & 7.5 & 2.8 & 5.3 & 2.3 & 11.1 & 88.9 & 44.0 & 1.7 & 29.8 & 24.5 \\
\hline Upstream channelized & 79.6 & 4.2 & 1.6 & 10.4 & 4.1 & 1.0 & 99.0 & 37.0 & 2.8 & 29.6 & 30.6 \\
\hline Downstream channelized & 80.0 & 8.5 & 5.0 & 4.3 & 2.2 & 3.1 & 96.9 & 32.4 & 1.7 & 33.3 & 32.6 \\
\hline All & 80.0 & 5.8 & 2.7 & 8.1 & 3.4 & 3.5 & 96.5 & 35.7 & 2.1 & 31.4 & 30.7 \\
\hline \multicolumn{12}{|c|}{ Percentage of relocations } \\
\hline Minimally engineered & 72.8 & 14.1 & 3.3 & 5.4 & 4.3 & 3.8 & 96.2 & 29.3 & 3.8 & 14.3 & 52.6 \\
\hline Upstream channelized & 66.1 & 5.8 & 4.1 & 6.4 & 17.5 & 2.2 & 97.8 & 21.4 & 10.7 & 33.7 & 34.2 \\
\hline Downstream channelized & 82.6 & 4.3 & 8.7 & 0.0 & 4.3 & 3.7 & 96.3 & 20.4 & 5.6 & 53.7 & 20.4 \\
\hline All & 69.6 & 8.4 & 4.2 & 5.6 & 12.2 & 3.0 & 97.0 & 24.1 & 7.5 & 29.7 & 38.8 \\
\hline \multicolumn{12}{|c|}{ Ivlev's selectivity coefficient } \\
\hline Minimally engineered & -0.06 & 0.31 & 0.07 & 0.01 & 0.31 & -0.49 & 0.04 & -0.20 & 0.38 & -0.35 & 0.36 \\
\hline Upstream channelized & -.09 & .17 & .43 & -.24 & .62 & .38 & -.01 & -.27 & .58 & .06 & .06 \\
\hline Downstream channelized & .02 & -.32 & .27 & -1.00 & .32 & .09 & 0 & -.23 & .52 & .23 & -.23 \\
\hline All & -.07 & .18 & .22 & -.18 & .57 & -.07 & 0 & -.20 & .55 & -.03 & .12 \\
\hline
\end{tabular}

\section{Summary and Discussion}

The goal of the CSRP is to improve fundamental understanding of reproductive ecology of the pallid sturgeon, and thereby to inform river and species management decisions. Management actions to increase reproductive success and survival of pallid sturgeon in the Lower Missouri River have been focused on flow regime, channel morphology, and propagation (U.S. Fish and Wildlife Service, 2003). Integration of our 2005-08 research provides some insights into how flow regime and re-engineered channel morphology may relate to pallid sturgeon reproduction and survival.

Emphasis on the role of flow regime evolves from its prominence as a driver of aquatic ecosystems (Poff and others, 1997), the degree of alteration of Missouri River flow regime (Galat and Lipkin, 2000), and the centrality of reservoir operations in Missouri River restoration strategies (Beechie, 1990; National Research Council, 2002; U.S. Fish and Wildlife Service, 2003; U.S. Army Corps of Engineers, 2004). A broad set of hypotheses for the functions of flow regime in pallid sturgeon reproduction (fig. 34) have been narrowed to focus specifically on spawning cues, habitat conditioning, habitat availability, and larval drift (Jacobson and Galat, 2008). The relevant management questions are: can flow modifications be designed - within other constraints - to improve the probabil- ity of reproduction and survival of pallid sturgeon and, if so, how can the modifications be optimized?

Re-engineering of channel morphology has focused on establishing more shallow, slow-current-velocity habitat (SWH) with the goal of increasing rearing habitat for larval and juvenile pallid sturgeon (U.S. Fish and Wildlife Service, 2003). A relevant management question is: where along the river will SWH projects be effective in providing habitat for retention and rearing of larvae?

The following sections discuss new understanding of ecological requirements of pallid sturgeon developed during 2005-2008 in context of the management actions. Although the quantity and quality of information on pallid sturgeon reproductive ecology have increased substantially since the inception of the CSRP, considerable uncertainty persists in understanding critical life-stage components. Results from the CSRP and related studies provide a basis for continued adaptive learning about how management of the river affects recovery of the species.

\section{Environmental Cues and Reproductive Readiness}

Converging lines of evidence support a model in which a gravid female sturgeon's reproductive maturation and 


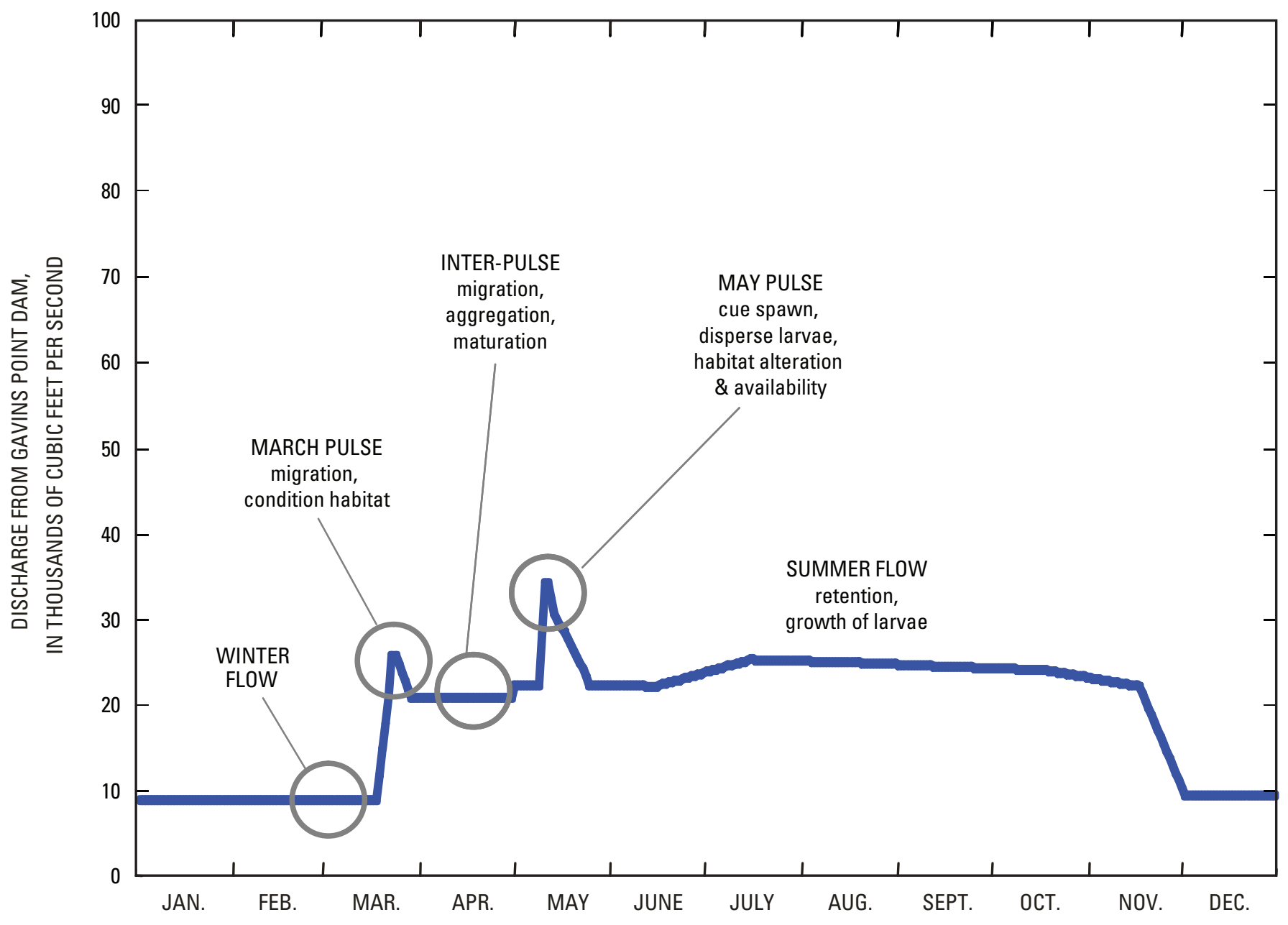

Figure 34. Hypothetical roles of flow regime in pallid sturgeon reproduction and recruitment.

readiness to spawn is cued many months before a predictable spawning date. Day length, because it is such a reliable annual cue, is a likely candidate to initiate the biological clock and define a temporal spawning window. Our data suggest that sturgeon at different locations between St. Louis, Missouri, and Gavins Point Dam, Nebraska, are all responding to the same early cue that starts their biological clocks ticking. The sturgeon then move upriver until they are reproductively ready to spawn and find the appropriate local conditions for spawning. We further hypothesize that within the spawning window, one or more additional, short-term, and specific cues may serve to signal ovulation and release of gametes. Because the sturgeon are likely spawning for a long period over a latitudinal gradient with variable conditions, ovulation and spawning may be cued by localized factors or events.

Of three potential spawning cues - water temperature, discharge, day of year - water temperature is the most likely proximate cue because of the fundamental physiological role of temperature in sturgeon embryo development and survival, and the sensitivity of many fish hormones to temperature change. Temperatures known to support sturgeon embryo survival existed within the downstream and upstream study sections during periods when telemetry data, PI values, or larval drift indicate that spawning was likely. There is no known direct link between discharge (independent from other factors) and sturgeon reproductive physiology, although indirect effects because of discharge-mediated water temperature changes are possible. Furthermore, discharge was extremely variable across study sections and years, although sturgeon exhibited no apparent changes in physiological spawning indicators. Alternatively, it is possible that neither temperature nor discharge is cueing spawning. What may be happening is simply the biological clock is advancing an individual fish's readiness to spawn day after day through the spawning period until the right moment, independent of temperature and discharge conditions. In such a case, site-specific information related to the presence of male sturgeon may be the most important factor to begin spawning.

Further refinement of our understanding of spawning cues will require defining more precise relations between environmental conditions and physiological indicators of reproductive physiology. Separation of the individual effects of 
discharge events, water temperature, and other possible factors will require replicates of field experiments (controlled releases from Gavins Point Dam and additional years of upstream/ downstream comparisons) combined with precise physiological indicators and focused laboratory studies.

\section{Implications of Documented Reproductive Movements}

Movement and behavior data for shovelnose sturgeon indicate consistent patterns of upstream spawning migrations before spawning. Shovelnose sturgeon appear to exhibit significant flexibility: spawning at many locations, over an extended period both in the mainstem and in tributaries. Shorter drift distances of shovelnose sturgeon larvae, earlier and more frequent reproduction, and less reliance on piscivory (Modde and Schmulbach, 1977; Carlson and others, 1985; Keenlyne and others, 1994), likely explain the differences in abundance between the two species.

Movement patterns of reproductive adult shovelnose sturgeon indicate that patterns of spring spawning migration vary between sexes. Female shovelnose sturgeon generally move upstream and spawn at the apex of their migration, whereas males choose to migrate upstream to one or several spawning locations, or choose to remain relatively sedentary. Female shovelnose sturgeon movement patterns support a consistent model, and we hypothesize that disrupted patterns of migration and behavior may translate into failure to spawn and reduced spawning success. Sudden temperature drops during a season of generally increasing temperatures may slow or disrupt spawning migrations or inhibit spawning.

Pallid sturgeon reproductive behaviors share many similarities with shovelnose sturgeon behavior. Pallid sturgeon migrate upstream to spawn and female pallid sturgeon likely spawn at the apex of their migratory movement. Similar to shovelnose sturgeon, pallid sturgeon males exhibit more complex migratory patterns, perhaps because of males seeking reproductive females or males attempting to spawn at multiple locations over the spawning period. The data indicate that spawning occurs at several locations in the Lower Missouri River. The three spawning patches that have been identified have a relatively narrow range of hydraulic and geomorphic characteristics. These patches, on the outside of revetted bends, have deep, relatively fast, turbulent flow, similar to convergent flow areas identified as spawning areas for white sturgeon (Paragamian and others, 2002; McDonald and others, 2006) and Chinese sturgeon (Fu and others, 2007). Convergent-flow areas are relatively insensitive to changes in discharge (Jacobson and others, 2009b) and may be less sensitive to temperature variations than other areas with suitable coarse substrate. Pallid sturgeon have shown the capacity to migrate long distances during spawning; however, because of the short duration of these intensive studies and the focus on spring migration and the spawning event, a complete under- standing of reproductive migration and critical pre-spawn and post-spawn habitats is lacking.

Although we have documented the fact that pallid sturgeon spawn over a broad geographic extent, the data are insufficient to determine whether or not spawning is more synchronous, and spawning locations more discrete and localized, than observed for shovelnose sturgeon. Less synchronous spawning and broadly distributed spawning sites allow for greater flexibility in a large, extremely mobile riverine species to select suitable spawning habitat and favorable conditions for fertilization, survival, hatch, and transport of young. Conversely, spawning at many locations scattered over a large spatial extent and over an extended period could increase the rarity of the species by encouraging hybridization by limiting spawning aggregations, reducing the likelihood of finding suitable mates, and reducing the effectiveness of management options like short-duration pulsed-flow releases and spatially isolated channel restoration projects. If additional research indicates discrete aggregations of pallid sturgeon in specific places and at specific times, it would follow that aspects of the flow regime or site-specific spawning habitat restoration actions could enhance sturgeon reproduction. Additional tracking and behavioral data are necessary to develop the information needed for managers to allocate their efforts among the various management options available.

This study is the first to document spawning of hatcherypropagated pallid sturgeon in the Missouri River. Evidence indicates that hatchery progeny are surviving, growing, reaching reproductive maturity, and now spawning; however, although this is a significant measure of success for the species recovery program, uncertainties remain about the viability of hatchery-raised progeny. It is unknown whether or not hatchery fish are responding to the same environmental cues as wild fish and whether or not hatchery fish are spawning successfully, in terms of producing viable fertilized eggs and larvae. Studies of reproductive success of steelhead trout, for example, have concluded that progeny of hatchery stocks have substantially decreased reproductive success (Araki and others, 2007). More information is needed to evaluate the relative contribution of hatchery fish to reproduction, recruitment, and population recovery in the Lower Missouri River. Additional data on the movement of adult wild sturgeon are needed to refine the understanding of sturgeon meta-populations and the genetic structure of populations (Schrey and Heist, 2007). Movement data on adult hatchery progeny may provide managers with information needed to balance the risk of population augmentation in the Missouri River to locally adapted populations in the middle and lower Mississippi River.

\section{Implications of Larval Drift Timing and Distance}

Our results support the hypothesis that spawning location, water velocities, growth rates, and drift dynamics determine the spatial and temporal distribution of pallid sturgeon and shovelnose sturgeon larvae and juveniles in the Missouri 
River. Natural recruitment of pallid sturgeon juveniles in the Missouri River appears to be low, especially in upstream segments (Dryer and Sandvol, 1993). Natural recruitment of shovelnose sturgeon juveniles in the Missouri River upstream from the Platte River currently (2009) may be dependent on successful spawning in tributaries, such as the Big Sioux River. Channel restoration activities that facilitate spawning further upstream or decrease drift distance (for example, by decreasing mean velocities, increasing channel length or width, or increasing channel complexity) may assist in recruiting Scaphirhynchus sturgeon in the Missouri River. Moreover, understanding of typical drift distances of larval Scaphirhynchus sturgeon may provide useful guidance for placement of channel-restoration projects that are intended to provide rearing habitat. Our drift data indicate that, with present channel velocities, rearing habitat would be most beneficial to pallid sturgeon downstream from river mile 378, or near the Kansas River confluence. Whether or not such habitat is limiting for survival of larval sturgeon has not yet been determined, nor has it been determined whether or not larval drift into the Mississippi River is beneficial or detrimental to survival. It also should be noted that other conditions may limit effectiveness of habitat restoration for larval rearing, such as aggregate dredging in the Kansas City reach of the Missouri River (Jacobson and others, 2009a).

\section{Flow and Channel Form Management in Mediating Sturgeon Reproduction}

The distribution of physical habitat along the Lower Missouri River (fig. 31) is the template provided for sturgeon to carry out their life history. Diminished habitat quantity and quality have been associated with decline of pallid sturgeon and, as a result, restoration of elements of the habitat template have been articulated as a primary goal for recovery of the species (U.S. Fish and Wildlife Service, 2000; 2003). Assessment of habitat dynamics indicates that areas of most habitat categories are relatively insensitive to changes in discharge that would occur with pulse-flow modifications (Jacobson and others, 2009b). In contrast, morphodynamic assessments indicated that flows similar in magnitude to those under consideration for pulse-flow modifications are capable of transporting sediment and altering habitat substrate (Elliott and others, 2009). Whether or not pulse flows can "condition" spawning substrate at the right time, in the right place, and in patches of the right size for successful pallid sturgeon spawning remains unknown. Improved understanding of where and when sturgeon spawn will be necessary to address these questions.

As documented in this report, tracking data document that hatchery-origin pallid sturgeon attempt to spawn on riprap on revetted outside bends. These observations support the idea that availability of habitats with necessary substrate characteristics may not be limiting for sturgeon spawning. Conversely, the abundance of this habitat could contribute to lack of reproductive success by decreasing densities of fish aggregations and probabilities of successful mating. Our assessments of habitat availability and use indicate that migrating adult sturgeon use specific areas within available habitats, characterized by high spatial variability of depth and velocity and low values of Froude number. Selection of these habitats provides insight into combinations of flow and channel form that support the energy requirements of migrating fish. Diminished areas of these habitats in the upper engineered section of the river support the idea that habitat is more limiting in this part of the river compared to upstream and downstream sections. Lack of suitable habitat in the upper engineered section may indicate a reproductive bottleneck if fish are energetically limited in their migration to spawning areas, or in finding mates.

\section{References Cited}

Arab, A., Wildhaber, M.L., Wikle, C.K., and Stoner, C.N., 2008, Modeling catch per unit area (CPUA) using a Bayesian zero-inflated model with application to channel catfish and shovelnose sturgeon in the Missouri River: North American Journal of Fisheries Management, v. 28, p. 1,044-1,058.

Araki, H., Cooper, B., and Blouin, M.S., 2007, Genetic effects of captive breeding cause a rapid, cumulative fitness decline in the wild: Science, v. 318, no. 5,847, p. 100-103.

Auer, N.A., 1982, Identification of larval fishes of the Great Lakes basin with emphasis on the Lake Michigan drainage: Ann Arbor, Michigan, Great Lakes Fishery Commission, Special Publication 82-3, 744 p.

Auer, N.A., 1996, Importance of habitat and migration to sturgeons with emphasis on lake sturgeon: Canadian Journal of Fisheries and Aquatic Sciences, v. 53, Supplement 1, p. $152-160$.

Bailey, R.M., and Cross, F.B., 1954, River sturgeons of the American genus Scaphirhynchus: characters, distribution, and synonymy: Papers of the Michigan Academy of Sciences, Arts, and Letters, v. 39, p. 169-208.

Bajer, P.G., and Wildhaber, M.L., 2007, Population viability analysis of Lower Missouri River shovelnose sturgeon with initial application to the pallid sturgeon: Journal of Applied Ichthyology, v. 23, p. 457-464.

Becker, G.C., 1983, Fishes of Wisconsin: Madison, Wisconsin, University of Wisconsin Press, 1,053 p.

Beechie, T.J., 1990, Evaluation of the TFW stream classification system: Stratification of physical habitat area and distribution: Final report, 1988-1990, Timber-Fish-Wildlife Project, Olympia, Washington, 85 p. 
Bemis, W.E., and Kynard, B., 1997, Sturgeon rivers: An introduction to acipenseriform biogeography and life history: Environmental Biology of Fishes, v. 48, no. 1-4, p. $167-184$.

Bergman, H.L., Boelter, A.M., Parady, K., Fleming, C., Keevin, T., Latka, D.C., Korschgen, C., Galat, D.L., Hill, T., Jordan, G., Krentz, S., Nelson-Stastny, W., Olson, M., Mestl, G.E., Rouse, K., and Berkley, J., 2008, Research needs and management strategies for pallid sturgeon recovery: William D. Ruckelshaus Institute of Environment and Natural Resources, University of Wyoming, Laramie Proceedings of a Workshop held July 31-August 2, 2007, 37 p.

Berry, C.R., and Young, B., 2004, Fishes of the Missouri National Recreational River, South Dakota and Nebraska: Great Plains Research, v. 14, p. 89-114.

Braaten, P.J., and Fuller, D.B., 2007, Growth rates of youngof-year shovelnose sturgeon in the Upper Missouri River: Journal of Applied Ichthyology, v. 23, p. 506-515.

Braaten, P.J., Fuller, D.B., Holte, L.D., Viste, W., Brandt, T.F., and Legare, R.G., 2008, Drift dynamics of larval pallid sturgeon and shovelnose sturgeon in a natural side channel of the Missouri River, Montana: North American Journal of Fisheries Management, v. 28, p. 808-826.

Braaten, P.J., and Guy, C.S., 2002, Life history attributes of fishes along the latitudinal gradient of the Missouri River: Transactions of the American Fisheries Society, v. 131, p. 931-945.

Bruch, R.M., and Binkowski, F.P., 2002, Spawning behavior of lake sturgeon (Acipenser fluvescens): Journal of Applied Ichthyology, v. 18, p. 570-590.

Bryan, J.L., Wildhaber, M.L., Papoulias, D.M., DeLonay, A.J., Tillitt, D.E., and Annis, M.L., 2007, Estimation of gonad volume, fecundity, and reproductive stage of shovelnose sturgeon using sonography and endoscopy with application to the endangered pallid sturgeon: Journal of Applied Ichthyology, v. 23, no. 4, p. 411-419.

Campton, D.E., Bass, A.L., Chapman, F.A., and Bowen, B.W., 2000, Genetic distinction of pallid, shovelnose, and Alabama sturgeon: emerging species and the US Endangered Species Act: Conservation Genetics, v. 1, p. 17-32.

Carlson, D.M., Pflieger, W.L., Trial, L., and Haverland, P.S., 1985, Distribution, biology and hybridization of Scaphirhynchus albus and S. platorynchus in the Missouri and Mississippi Rivers, Missouri: Environmental Biology of Fishes, v. 14, p. 51-59.

Christenson, L.M., 1975, The shovelnose sturgeon, Scaphirhynchus platorynchus (Rafinesque), in the Red CedarChippewa River System: Wisconsin DNR Research Report $82,23 \mathrm{p}$.
Cohen, D., 1967, Optimizing reproduction in varying environments: Journal of Theoretical Biology, v. 16, p. 1-14.

Colwell, R.K., 1974, Predictability, constancy, and contingency of periodic phenomena: Ecology, v. 55, no. 5, p. $1,148-1,153$.

Cooper, A.B., and Millspaugh, J.J., 1999, The application of discrete choice models to wildlife resource selection studies: Ecology, v. 80, p. $566-575$.

Cooper, A.B., and Millspaugh, J.J., 2001, Accounting for variation in resource availability and annual behavior in resource selection studies, in Millspaugh, J.J., and Marzluff, J.M., eds., Radio Tracking and Animal Populations: San Diego, California, Academic Press, p. 243-273.

Curtis, G.L., Ramsey, J.S., and Scarnecchia, D.L., 1997, Habitat use and movements of shovelnose sturgeon in Pool 13 of the upper Mississippi River during extreme low flow conditions: Environmental Biology of Fishes, v. 50, no. 2, p. $175-182$.

DeLonay, A.J., Papoulias, D.M., Wildhaber, M.L., Annis, M.L., Bryan, J.L., Griffith, S.A., Holan, S.H., and Tillitt, D.E., 2007a, Use of behavioral and physiological indicators to evaluate Scaphirhynchus sturgeon spawning success: Journal of Applied Ichthyology, v. 23, no. 4, p. 428-435.

DeLonay, A.J., Papoulias, D.M., Wildhaber, M.L., Mestl, G.E., Everitt, D.W., and Chojnacki, K.A., 2007b, Movement, habitat use, and reproductive behavior of shovelnose sturgeon and pallid sturgeon in the Lower Missouri River, in Korschgen, C., ed., Factors affecting the reproduction, recruitment, habitat, and population dynamics of Pallid Sturgeon and Shovelnose Sturgeon in the Missouri River: U.S. Geological Survey Open-File Report 2007-1262, p. 23-102. http://pubs.usgs.gov/of/2007/1262/

Deng, D.-F., Koshio, S., Yokoyama, S., Bai, S.C., Shao, Q., Cui, Y., and Hung, S.S.O., 2003, Effects of feeding rate on growth performance of white sturgeon (Acipenser transmontanus) larvae: Aquaculture, v. 217, no. 1-4, p. 589-598.

Dettlaff, T.A., Ginsburg, A.S., and Schmalhausen, O.I., 1993, Sturgeon fishes: Developmental biology and aquaculture: Berlin, Springer-Verlag, $300 \mathrm{p}$.

Dryer, M.P., and Sandvol, A.J., 1993, Recovery plan for the pallid sturgeon (Scaphirhynchus albus): U.S. Fish and Wildlife Service, $55 \mathrm{p}$.

Echols, K.R., Brumbaugh, W.G., Orazio, C.E., May, T.W., Poulton, B.C., and Peterman, P.H., 2008, Distribution of pesticides, PAHs, PCBs and bioavailable metals in depositional sediments of the Lower Missouri River, USA: Archives of Environmental Contamination and Toxicology, v. 55 , p. $161-172$. 
Elliott, C.M., and Jacobson, R.B., 2006, Geomorphic classification and assessment of channel dynamics in the Missouri National Recreational River, South Dakota and Nebraska: U.S. Geological Survey Scientific Investigations Report 2006-5313, 66 p. http://pubs.er.usgs.gov/usgspubs/sir/ $\operatorname{sir} 20065313$

Elliott, C.M., Reuter, J.M., and Jacobson, R.B., 2009, Channel morphodynamics in four reaches of the Lower Missouri River, 2006-07: U.S. Geological Survey Scientific Investigations Report 2009-5074, 258 p. http://pubs.usgs.gov/ sir/2009/5074/

Fu, X.-1., Li, D.-m., and Jin, G.-y., 2007, Calculation of flow field and analysis of spawning sites for Chinese sturgeon in the downstream of Gezhouba Dam: Journal of Hydrodynamics, ser. B, v. 19, no. 1, p. 78-83.

Fujioka, Y., 2006, Patterns of sex ratio response to water temperature during sex determination in honmoroko Gnathopogon caerulescens: Fisheries Science, v. 72, no. 5, p. 1,034-1,041.

Gaeuman, D., and Jacobson, R.B., 2005, Aquatic habitat mapping with an acoustic Doppler current profiler-considerations for data quality, U.S. Geological Survey Open-File Report 2005-1163, 20 p.

Gaeuman, D., and Jacobson, R.B., 2006, Acoustic bed velocity and bed load dynamics in a large sand bed river: Journal of Geophysical Research, v. 111, p. 1-14.

Gaeuman, D., and Jacobson, R.B., 2007a, Field assessment of alternative bedload transport estimators: Journal of Hydraulic Engineering, v. 133, no. 12, p. 1,319-1,328.

Gaeuman, D., and Jacobson, R.B., 2007b, Quantifying fluid and bed dynamics for characterizing benthic physical habitat in large rivers: Journal of Applied Ichthyology, v. 27, p. 359-364.

Galat, D.L., Berry, C.R., Peters, J., and White, R.G., 2005, Missouri River Basin, in Benke, A.C., and Cushing, C.E., eds., Rivers of North America: Oxford, Elsevier, p. 427480 .

Galat, D.L., and Lipkin, R., 2000, Restoring ecological integrity of great rivers: historical hydrographs aid in defining reference conditions for the Missouri River: Hydrobiologia, v. 422 , p. 29-48.

Galloway, W.E., 2005, Gulf of Mexico basin depositional record of Cainozoic North American drainage basin evolution, in Blum, M.D., Marriott, S.B., and Leclair, S.F., eds., Fluvial Sedimentology VII, IAS Special Publication 35, Blackwell Scientific Press, p. 409-423.
Garvey, J.E., Heist, E.J., Brooks, R.C., Herzog, D.P., Hrabik, R.A., Killgore, K.J., Hoover, J.J., and Murphy, C.E., 2009, Current status of the pallid sturgeon in the Middle Mississippi River: habitat, movement, and demographics: U.S. Army Corps of Engineers, 353 p. http://fishdata.siu.edu/ pallid

Gerrity, P.C., Guy, C.S., and Gardner, W.M., 2008, Habitat use of juvenile pallid sturgeon and shovelnose sturgeon with implication for water-level management in a downstream reservoir: North American Journal of Fisheries Management, v. 28, p. 832-843.

Gisbert, E., and Doroshov, S.I., 2003, Histology of the developing digestive system and the effect of food deprivation in larval green sturgeon (Acipenser medirostris): Aquatic Living Resources, v. 16, p. 77-89.

Gisbert, E., and Williot, P., 2007, Larval behaviour and effect of the timing of initial feeding on growth and survival of Siberian sturgeon (Acipenser baeri) larvae under small scale hatchery production: Aquaculture, v. 156, p. 63-76.

Golder Associates, L., 2006, Upper Columbia River juvenile white sturgeon monitoring: Phase 3 investigations, August 2004 - February 2005: Castlegar, B.C., Canada, Report to BC Hydro 04-1480-051F, 187 p.

Heim, G.E.J., and Howe, W.B., 1963, Pleistocene drainage and depositional history in northeastern Missouri: Transactions of the Kansas Academy of Science, v. 66, p. 378-392.

Hesse, L.W., 2008, Main channel biomonitoring Middle Missouri River - Performance report: River Ecosystems, Incorporated, $16 \mathrm{p}$.

Hesse, L.W., Schmulbach, J.C., Carr, J.M., Keenlyne, K.D., Unkenholz, D.G., Robinson, J.W., and Mestl, G.E., 1989, Missouri River fishery resources in relation to past, present, and future stresses, in Dodge, D.P., ed., Proceedings of the International Large River Symposium: Ottawa, Canadian Special Publication of Fisheries and Aquatic Sciences 106, p. 353-371.

Holan, S.H., Davis, G., Wildhaber, M.L., DeLonay, A.J., and Papoulias, D.M., 2009, Markov switching models with application to predicting spawning success of shovelnose sturgeon: Journal of the Royal Statistical Society: Series C (Applied Statistics), v. 58, p. 1-18.

Hrabik, R.A., Herzog, D.P., Ostendorf, D.E., and Petersen, M.D., 2007, Larvae provide first evidence of successful reproduction by pallid sturgeon Scaphirhynchus albus, in the Mississippi River: Journal of Applied Ichthyology, v. 23, p. 436 .

Hubbs, C.L., 1955, Hybridization between fish species in nature: Systematic Zoology, v. 4, p. 1-20. 
Humphries, P., Serafini, L.G., and King, A.J., 2002, River regulation and fish larvae: variation through space and time: Freshwater Biology, v. 47, p. 1,307-1,331.

Jacobson, R.B., 2008, Analysis of pulsed flow modification alternatives, Lower Missouri River, 2005: U.S. Geological Survey Open-File Report 2008-1113, 14 p. http://pubs.usgs. gov/of/2008/1113

Jacobson, R.B., Blevins, D.W., and Bitner, C.J., 2009a, Sediment regime constraints on river restoration - An example from the Lower Missouri River, in James, L.A., Rathburn, S.L., and Whittecar, G.R., eds., Management and restoration of fluvial systems with broad historical changes and human impacts: Denver, Colo., Geological Society of America Special Paper 451, p. 1-22.

Jacobson, R.B., and Galat, D.L., 2006, Flow and form in rehabilitation of large-river ecosystems: An example from the Lower Missouri River: Geomorphology, v. 77, no. 3-4, p. 249-269.

Jacobson, R.B., and Galat, D.L., 2008, Design of a naturalized flow regime on the Lower Missouri River: Ecohydrology, v. 1, no. 2, p. $81-104$.

Jacobson, R.B., Johnson, H.E., III, and Dietsch, B.J., 2009b, Hydrodynamic simulations of physical aquatic habitat availability for pallid sturgeon in the Lower Missouri River, at Yankton, South Dakota, Kenslers Bend, Nebraska, Little Sioux, Iowa, and Miami, Missouri, 2006-07: U.S. Geological Survey Scientific Investigations Report 2009-5058, 67 p. http://pubs.usgs.gov/sir/2009/5058/

Jacobson, R.B., Johnson, H.E., Reuter, J.M., and Elliott, C.M., 2007, The roles of physical habitat in reproduction and survival of pallid sturgeon and shovelnose sturgeon in the Lower Missouri River, 2005-06, in Korschgen, C., ed., Factors affecting the reproduction, recruitment, habitat, and population dynamics of Pallid Sturgeon and Shovelnose Sturgeon in the Missouri River: U.S. Geological Survey Open-File Report 2007-1262, p. 143-212. http://pubs.usgs. gov/of/2007/1262/

Jager, H.I., Van Winkle, W., Chandler, J.A., Lepla, K.B., Bates, P.D., and Counihan, T.D., 2002, A simulation study of factors controlling white sturgeon recruitment in the Snake River, in Biology, management, and protection of North American sturgeon, Symposium 28, Bethesda, Maryland, American Fisheries Society, p. 127-150.

Kah, O., Madigou, T., Mazurais, D., and Le Dréan, G., 2000, Aspects of the central regulation of reproduction in teleost fish, in Reproductive Physiology of Fish, Proceedings of the 6th International Symposium on Reproductive Physiology of Fish, 4-9 July 1999, Institute of Marine Research and University of Bergen, p. 499.
Kallemeyn, L.W., 1983, Status of the pallid sturgeon: Fisheries, v. 8, no. 1, p. 3-9.

Keenlyne, K.D., 1997, Life history and status of the shovelnose sturgeon, Scaphirhynchus platorynchus: Environmental Biology of Fishes, v. 48, p. 291-298.

Keenlyne, K.D., Graham, L.K., and Reed, B.C., 1994, Hybridization between the pallid and shovelnose sturgeons: Proceedings of the South Dakota Academy of Sciences, v. 73, p. 59-66.

Keenlyne, K.D., and Jenkins, L.G., 1993, Age at sexual maturity of the pallid sturgeon: Transactions of the American Fisheries Society, v. 122, p. 393-396.

Kennedy, A.J., Daugherty, D.J., Sutton, T.M., 2007, Population characteristics of shovelnose sturgeon in the Upper Wabash River, Indiana: North American Journal of Fisheries Management, v. 27, p. 52-62.

King, P.B., and Beikman, H.M., 1974, Geologic map of the United States: Reston, Virginia, U.S. Geological Survey, scale 1:2,500,000, map 1 sheet, $40 \mathrm{p}$.

Korschgen, C.E., 2007, Factors affecting the reproduction, recruitment, habitat, and population dynamics of pallid sturgeon and shovelnose sturgeon in the Missouri River: U.S. Geological Survey Open-File Report 20071262, 280 p. http://pubs.usgs.gov/of/2007/1262/

Kynard, B., 1997, Life history, latitudinal patterns, and status of the shortnose sturgeon, Acipenser brevirostrum: Environmental Biology of Fishes, v. 48, p. 319-334.

Kynard, B., Henyey, E., and Horgan, M., 2002, Ontogenetic behavior, migration, and social behavior of pallid sturgeon, Scaphirhynchus albus, and shovelnose sturgeon, S. platorynchus, with notes on the adaptive significance of body color: Environmental Biology of Fishes, v. 62, p. 389-403.

Kynard, B., Parker, E., Pugh, D., and Parker, T., 2007, Use of laboratory studies to develop a dispersal model for Missouri River pallid sturgeon early life intervals: Journal of Applied Ichthyology, v. 23, p. 365-374.

Lam, T.J., 1983, Environmental influences on gonadal activity in fish, in Hoar, W.S., Randall, D.J., and Donaldson, E.M., eds., Fish Physiology Volume IX, Reproduction Part B: New York, New York, Academic Press, p. 65-116.

Langbein, W.B., and Schumm, S.A., 1958, Yield of sediment in relation to mean annual precipitation: American Geophysical Union Transactions, v. 39, p. 1,076-1,084.

Langer, W.H., Brady, L.L., Smith, D.D., and Milick, R.A., 2002, Geologic map of the St. Joseph area, Missouri and Kansas: U.S. Geological Survey Miscellaneous Field Studies Map, MF-2374, ver. 1.0. 
Laustrup, M.S., Jacobson, R.B., and Simpkins, D.G., 2007, Distribution of potential spawning habitat for sturgeon in the Lower Missouri River, 2003-06: U.S. Geological Survey Open-File Report 2007-1192, 26 p. http://pubs.usgs. gov/of/2007/1192/

Mayden, R.L., and Kuhajda, B.R., 1997, Threatened fishes of the world: Scaphirhynchus albus (Forbes \& Richardson, 1905) (Acipenseridae): Environmental Biology of Fishes, v. 48 , p. $420-421$.

McDonald, R.R., Barton, G.J., Nelson, J.M., and Paragamian, V.L., 2006, Modeling hydraulic and sediment transport processes in white sturgeon spawning habitat on the Kootenai River, in Joint 8th Federal Interagency Sedimentation and 3rd Federal Interagency Hydrologic Modeling Conference, p. 8 .

Meade, R.H., 1995, Contaminants in the Mississippi River, 1987-92: U.S. Geological Survey Circular 1133 accessed August 31, 2009 at URL http://pubs.usgs.gov/circ/circ1133/

Millspaugh, J.J., and Marzluff, J.M., 2001, Radio tracking of animal populations: San Diego, Calif., Academic Press, $474 \mathrm{p}$.

Modde, T., and Schmulbach, J.C., 1977, Food and feeding behavior of the shovelnose sturgeon, Scaphirhynchus platorynchus, in the unchannelized Missouri River, South Dakota: Transactions of the American Fisheries Society, v. 106, p. $602-608$.

Moos, R.E., 1978, Movement and reproduction of shovelnose sturgeon, Scaphirhynchus platorynchus (Rafinesque), in the Missouri River in South Dakota: University of South Dakota, Dissertation, 213 p.

Munro, A.D., Scott, A.P., and Lam, T.J., 1990, Reproductive seasonality in teleosts: Environmental Influences: Boca Raton, Florida, CRC Press, Inc., 254 p.

National Research Council, 2002, The Missouri River ecosystem, exploring the prospects for recovery: Washington, D.C., National Academy Press, 176 p.

Papoulias, D.M., Braaten, P.J., DeLonay, A.J., Doyle, W.J., Fuller, D.B., Simpkins, D.G., Wildhaber, M.L., and Galat, D.L., 2007a, Evidence for protracted spawning in shovelnose sturgeon from the Missouri River [abstract]: Proceeding of the American Fisheries Society 137th Annual Meeting, San Francisco, California, September 2-6, 2007, p. 107-136.

Papoulias, D.M., DeLonay, A.J., Wildhaber, M.L., Annis, M.L., and Tillitt, D.E., 2007b, Incidence and severity of intersex in sturgeons: are contaminants the cause [abstract]: Proceeding of the American Fisheries Society 137th Annual Meeting, San Francisco, California, September 2-6, 2007.
Paragamian, V.L., and Wakkinen, V.D., 2002, Temporal distribution of Kootenai River white sturgeon spawning events and the effect of flow and temperature: Journal of Applied Ichthyology, v. 18 , no. 4-6, p. 542-549.

Paragamian, V.L., Wakkinen, V.D., and Kruse, G., 2002, Spawning locations and movement of Kootenai River white sturgeon: Journal of Applied Ichthyology, v. 18, no. 4-6, p. 608-616.

Park, B.J., and Kidd, K., 2005, Effects of the synthetic estrogen ethinylestradiol on early life stages of mink frogs and green frogs in the wild and in situ: Environmental Toxicology and Chemistry, v. 24, no. 8, p. 2,027-2,036.

Pegg, M.A., Pierce, C.L., and Roy, A., 2003, Hydrological alteration along the Missouri River basin: a time series approach: Aquatic Sciences, v. 65, p. 63-72.

Peters, E.J., and Parham, J.E., 2007, Ecology and management of sturgeon in the Lower Platte River, Nebraska: Nebraska Game and Parks Commission Nebraska Technical Series no. 18,208 p.

Petty, J.D., Huckins, J.N., Orazio, C.E., Lebo, J.A., Poulton, B.C., Gale, R.W., Charbonneau, C.S., and Kaiser, E.M., 1995, Determination of waterborne bioavailable organochlorine pesticide residues in the Lower Missouri River: Environmental Science and Technology, v. 29, p. 2,5612,566 .

Poff, N.L., Allan, J.D., Bain, M.B., Karr, J.R., Prestegaard, K.L., Richter, B.D., Sparks, R.E., and Stromberg, J.C., 1997, The natural flow regime: Bioscience, v. 47, p. $769-784$.

Quist, M.C., Boelter, A.M., Lovato, J.M., Korfanta, N.M., Bergman, H.L., Latka, D.C., Korschgen, C., Galat, D.L., Krentz, S., Oetker, M., Olson, M., Scott, C.M., and Berkley, J., 2004, Research and assessment needs for pallid sturgeon recovery in the Missouri River--Final report to the U.S. Geological Survey, U.S. Army Corps of Engineers, U.S. Fish and Wildlife Service, and U.S. Environmental Protection Agency: Laramie, Wyo., William D. Ruckelshaus Institute of Environment and Natural Resources, University of Wyoming, $82 \mathrm{p}$.

Redding, J.M., and Patino, R., 1993, Reproductive physiology, in Evans, D.H., ed., The physiology of fishes: Boca Raton, Florida, CRC Press, p. 503-534.

Reuter, J.M., Jacobson, R.B., Elliott, C.M., and DeLonay, A.J., 2009, Assessment of Lower Missouri River physical aquatic habitat and its use by adult sturgeon (genus Scaphirhynchus) 2005-07: U.S. Geological Survey Scientific Investigations Report 2009-5121, 81 p. http://pubs.er.usgs.gov/ usgspubs/sir/sir20095121 
Reuter, J.M., Jacobson, R.B., Elliott, C.M., Johnson, H.E., III, and DeLonay, A.J., 2008, Hydraulic and substrate maps of reaches used by sturgeon (Genus Scaphirhynchus) in the Lower Missouri River, 2005-07: U.S. Geological Survey Data Series Report 386, 442 p. http://pubs.usgs.gov/ds/386/

Scheidegger, K.J., and Bain, M.B., 1995, Larval fish in natural and regulated rivers: assemblage composition and microhabitat use: Copeia, v. 1, p. 125-135.

Schrey, A.W., and Heist, E.J., 2007, Stock structure of pallid sturgeon analyzed with micosatellite loci: Journal of Applied Ichthyology, v. 23, p. 297-303.

Simons, A.M., Wood, R.M., Heath, L.S., Kuhajda, B.R., and Mayden, R.L., 2001, Phylogenetics of Scaphirhynchus based on mitochondrial DNA sequences: Transactions of the American Fisheries Society, v. 130, p. 359-366.

Simpkins, D.G., and LaBay, S.R., 2007, Site-specific assessment of spawning behavior and habitat use, in Korschgen, C., ed., Factors affecting the reproduction, recruitment, habitat, and population dynamics of Pallid Sturgeon and Shovelnose Sturgeon in the Missouri River: U.S. Geological Survey Open-File Report 2007-1262, p. 217-254. http:// pubs.usgs.gov/of/2007/1262/

Snyder, D.E., 1980, Characteristics for distinguishing the protolarvae of paddlefish and sturgeon: American Fisheries Society Early Life History Newsletter, v. 1, p. 9-10.

Snyder, D.E., 2002, Pallid and shovelnose sturgeon larvae-morphological description and identification: Journal of Applied Ichthyology, v. 18, p. 240-265.

Sustainable Ecosystems Institute, 2008, Review of comprehensive sturgeon research program: Sustainable Ecosystems Institute, 49 p. http://sei.org/sturgeon/MR_USGS-ProgramFinal-Report.pdf

Teh, S.J., Miller, C.E., and Hinton, D.E., 2000, Hermaphroditism in laboratory-cultured albino western mosquito fish: Journal of Aquatic Animal Health, v. 12, p. 78-80.

Tranah, G., Campton, D.E., and May, B., 2004, Genetic Evidence for Hybridization of Pallid and Shovelnose Sturgeon: Journal of Heredity, v. 95, no. 6, p. 474-480.

U.S. Army Corps of Engineers, 1960, 1960 River Miles for the Missouri River digital data: Omaha, Nebraska.

U.S. Army Corps of Engineers, 2004, Summary Missouri River final environmental impact statement--Master water control manual review and update: U.S. Army Corps of Engineers, Northwest Division, 28 p.

U.S. Army Corps of Engineers, 2006, Missouri River Mainstem Reservoir System - Master Water Control Manual, Missouri River Basin: Omaha, Nebraska, Northwestern Division, Missouri River Basin, Water Management Division, $431 \mathrm{p}$.
U.S. Army Corps of Engineers, 2008, Missouri River Mainstem System 2008-09 Annual Operating Plan: Omaha, Nebraska, Northwestern Division, Missouri River Basin, Water Management Division, $85 \mathrm{p}$.

U.S. Department of Agriculture, 2006, National Agriculture Imagery Program (NAIP) digital data: Salt Lake City, Utah, Farm Service Agency Aerial Photography Field Office.

U.S. Fish and Wildlife Service, 2000, Biological opinion on the operation of the Missouri River main stem reservoir system, operation and maintenance of the Missouri River bank stabilization and navigation project, and operation of the Kansas River reservoir system: U.S. Fish and Wildlife Service, $286 \mathrm{p}$.

U.S. Fish and Wildlife Service, 2003, Amendment to the 2000 biological opinion on the operation of the Missouri River main stem reservoir system, operation and maintenance of the Missouri River bank stabilization and navigation project, and operation of the Kansas River reservoir system: U.S. Fish and Wildlife Service, 308 p. http://www.nwd-mr. usace.army.mil/mmanual/FinalBO2003.pdf

Wallus, R., 1990, Family Acipeneridae, in Wallus, R., Simon, T.P., and Yeager, B.L., eds., Reproductive biology and early life history of fishes in the Ohio River drainage, Volume I: Acipenseridae through Esocidae: Chattanooga, Tennessee, Tennessee Valley Authority, p. 27-46.

Whiteman, K.W., Travnichek, V.H., Wildhaber, M.L., DeLonay, A.J., Papoulias, D.M., and Tillitt, D.E., 2004, Age estimation for shovelnose sturgeon: a cautionary note based on annulus formation in pectoral fin rays: North American Journal of Fisheries Management, v. 24, p. 731-734.

Wildhaber, M.L., DeLonay, A.J., Papoulias, D.M., Galat, D.L., Jacobson, R.B., Simpkins, D.G., Braaten, P.J., Korschgen, C.E., and Mac, M.J., 2007a, A conceptual life-history model for pallid and shovelnose sturgeon: U.S. Geological Survey Circular 1315, 18 p. http://pubs.usgs.gov/circ/2007/1315/

Wildhaber, M.L., Papoulias, D.M., DeLonay, A.J., Tillitt, D.E., Bryan, J.L., and Annis, M.L., 2007b, Physical and hormonal examination of Missouri River shovelnose sturgeon reproductive stage: a reference guide: Journal of Applied Ichthyology, v. 23, no. 4, p. 382-401.

Wildhaber, M.L., Papoulias, D.M., DeLonay, A.J., Tillitt, D.E., Bryan, J.L., Annis, M.L., and Allert, J.A., 2005, Gender identification of shovelnose sturgeon using ultrasonic and endoscopic imagery and the application of the method to the pallid sturgeon: Journal of Fish Biology, v. 67, no. 1, p. 114-132.

Wingfield, J.C., Han, T.P., Levin, R., and Honey, P., 1992, Environmental predictability and control of gonadal cycles in birds: Journal of Experimental Zoology, v. 261, p. 214-231. 
Prepared by:

Rolla Publishing Service Center

For more information concerning this publication, contact:

Director

U.S. Geological Survey

Columbia Environmental Research Center

4200 New Haven Road

Columbia, M0 65201

(573) 875-5399

Or visit the Columbia Environmental Research Center website at: http://www.cerc.usgs.gov 

